\title{
The Perception of Web 2.0 Technologies on Teaching and Learning in Higher Education: A Case Study
}

\author{
Stacia Ann Zelick \\ School of Business and Technology, Capella University, Minneapolis, USA \\ Email: szelick@capellauniversity.edu \\ Received June $7^{\text {th }}, 2013$; revised July $7^{\text {th }}, 2013$; accepted July $14^{\text {th }}, 2013$
}

\begin{abstract}
Copyright (c) 2013 Stacia Ann Zelick. This is an open access article distributed under the Creative Commons Attribution License, which permits unrestricted use, distribution, and reproduction in any medium, provided the original work is properly cited.
\end{abstract}

\begin{abstract}
The purpose of this study was to examine faculty members' perception of Web 2.0 technologies on teaching and learning in higher education compared to traditional classroom teaching methods in programs at a higher education institutions to establish if relationships prevailed in their delivery of courses through the use of Web 2.0 technologies compared with traditional classroom delivery of courses; their overall satisfaction; the level of faculty development programs available; and their perceived effectiveness and impact of faculty development and issues and barriers affecting technology integration. This study also examined the influence of gender, age, and employment status on faculty members' perceptions of Web 2.0 technologies on teaching and learning in higher education compared to traditional classroom teaching methods. This study used a nonexperimental, quantitative descriptive research design to investigate faculty members' perception of Web 2.0 technologies on teaching and learning in higher education compared to traditional classroom teaching methods. Participants for this study included full-time and part-time faculty members teaching at a public university in the United States. The results indicated that there is a relationship between faculty members' perception of teaching college courses utilizing Web 2.0 technologies versus traditional classroom method; there is a relationship between faculty members' gender and perception regarding their use of Web 2.0 technologies in their courses; and there was a relationship between faculty members' age and perception regarding their use of Web 2.0 technologies in their courses.
\end{abstract}

Keywords: Web 2.0 Technologies; Higher Education; Blogs; Facebook; Podcast; Second Life; Skype; Twitter; Wiki; YouTube

\section{Introduction}

There are a number of institutions that influence information technology innovation, including government authorities, international agencies, professional and trade and industry associations, research-oriented higher education institutions, trendsetting corporations, multinational corporations, financial institutions, labor organizations, and religious institutions (King et al., 1994). Institutions of higher education, being one of the institutions that have influenced information technology innovation, have gone through a dramatic change over the past several years (Sibbet, 1997).

In today's economy, organizations must constantly produce at the highest human and technological levels in order to remain competitive (Fillion, Limayem, Laferrière, \& Mantha, 2006). Schools, colleges, and universities are increasingly turning their traditional classrooms into digitized technology rooms (Weyant \& Gardner, 2010) and it is becoming a "a transition from academic broadcasting to collaborative facilitation, from linear to student-directed teaching delivery" (Barnatt, 2008: p. 47). From blogs to virtual worlds, and wikis to interactive technology, students are now learning through a number of new channels, and it is up to the faculty members to infuse this technology into their curriculums (Chuang, 2004). With technology dou- bling every 18 months (Sibbet, 1997), just keeping up with it can be a daunting task in itself, let alone trying to figure out how best to leverage information technology into an organization. Robey and Boudreau (1999) state that "each new generation of technology and each major technological advance has been accompanied by energetic claims that organizations as we know them will be radically and fundamentally altered" (p. 167).

In order for faculty members to remain competitive and sustainable in this digital age, professional development on the use of technology and how to infuse technology into course curricula is a requirement (Alsaady, 2007). In higher education, as the significance on technology increases, so does the requirement for technologically educated faculty members (Chuang, 2004). Chuang posits that "the major concerns in educational technology have moved away from hardware- and softwarerelated issues; instructional strategies, professional development, and continuity of administrative support have emerged as the new issues" (2004: p. 1). Hemmi, Bayne, and Land (2009) argue that "the technology infrastructure of 'Web 2.0' and its associated applications provide the higher education community with authoring and community-building capabilities, the pedagogical implications of which are still largely unexplored" (p. 19). Identifying the aspects of effectiveness and potential 
impacts of faculty development will recognize areas of success and failure and will contribute to improving the content of faculty development (Al-Washahi, 2007). The results are expected to empower the faculty members to actively infuse technology into their curriculum and classroom, thus providing a state of the art experience for the student community at institutions of higher education.

Institutions of higher education are now playing to catch up because the students already have more knowledge about content sharing and Web 2.0 technologies than their professors do (Barnatt, 2008). The traditional college students, aged $18-25$ years old, grew up in the digital world of computers are used to this technology (Weyant \& Gardner, 2010). In order to get the faculty members up to speed on these technologies so they are not only knowledgeable of the technology, but able to infuse the technology into their curriculums, and faculty development programs are critical. Rich (2008) proposes the following five competencies that faculty members (as well as students) must acquire in order to take full advantage of the various Web 2.0 technologies. These competencies include accurate searching skills through a variety of search tools, judging authoritativeness to be able to acknowledge bias and appropriate use of citing materials, use of a range of channels to harmonize information, structural understanding of how Web 2.0 content is formed, and positive engagement (Rich, 2008).

\section{Background of the Study}

For the past thirty years, information technologies have revolutionized the way faculty members teach and students learn (Weyant \& Gardner, 2010). In today's economy institutions of higher education must constantly produce at the human and technological levels in order to remain competitive (Fillion et al., 2006). With mainframe computers introduced in 1967, handheld digital calculators in 1970, personal computers in 1977, the Internet and Microsoft in 1995, and the extranet in 1998 (Sibbet, 1997) technology has been on the rise for over 42 years and there does not appear to be a hiccup or stop in sight. "In some schools, the Internet and other technologies are being integrated at the institutional level" (Gottwald, 2005: p. 2).

What used to be one-way communication and learning has quickly become an interactive platform for communication and learning. "Since the earliest use of the World Wide Web for teaching and learning, one of the most powerful elements has been the ability to engage learners in an interactive format" (Hazari, North, \& Moreland, 2009: p. 187). The United States Department of Education established a project in 1998 to advocate the effective infusion of technology into teacher education (Thompson, 2005). This project was established 21 years after the personal computer was introduced, and a mere three years after the Internet was introduced (Sibbet, 1997).

This is not surprising as the Internet has become the world's most widespread unrestricted communication system (Laudon \& Laudon, 2009: p. 200). "Increased attention to student engagement and active learning strategies have become particularly relevant in today's classroom environments" (Williams \& Chinn, 2009: p. 165). In 2000, the use of technology in instruction was ranked as the second most significant issue confronting public education; by 2020 is it expected to be the most significant issue to confront public education (Hikmet, Taylor, \& Davis, 2008). This development is an innovation in higher education. How faculty members are integrating Web 2.0 tech- nologies into their curriculums and what specific Web 2.0 technologies are actually being integrated can lay the foundation to what tomorrow will bring for education, the faculty and the students. Thompson (2005) states that "teacher education must be a strong force to promote appropriate use of technology to support educational renewal and to prepare a skilled work force for our Information Society" (p. 331).

With technology continuing to expand at a rapid rate and being ever changing (Rockart, Earl, \& Ross, 1996), trying to constantly be on the cutting edge of technology in higher education is an interesting paradigm. "In some schools, the Internet and other technologies are being integrated at the institutional level; with a student's complete academic experience-from application through registration and tuition payment, to final examination and course grade-occurring on-line" (Gottwald, 2005: p. 2). The rapidly growing technology infrastructure at institutions of higher education to meet the instructional and research needs of faculty, staff, and students (Alsaady, 2007) is making faculty development with the use of technology a requirement. Between 2002 and 2006, online learning increased by $21.5 \%$ while the entire higher education student body only increased by $1.5 \%$ (Yates, 2010).

Li and Pitts (2009) indicate that "one key area where Webbased technologies are predicted to have a significant impact is in their ability to transform the way in which professors and students are able to communicate and interact with one another" (p. 175). With the significant increase in online learning over the past years (Lee, 2010), this prediction is already a reality at institutions of higher education. Rich (2008) states that "members of the millennial generation are acquiring the sort of adult information navigation skills in an environment where folksonomies are widely used, and this potentially raises challenges for educators in universities as to how to promote information literacy" (p. 73). The reality is that the millennial generation, those born between 1982 and 2000, grew up with this technology so the faculty members are at a clear disadvantage (Barnatt, 2088). The role of the professor has gone from that of a broadcaster to a collaborative facilitator, and the learning delivery has gone from linear to student directed (Barnatt, 2008). The needs of the student population in institutions of higher education are rapidly evolving into the most technological advanced generation and if institutions and faculty members want to remain competitive must infuse technology with curriculums and continuously improve the technological offerings.

There are many factors that present challenges in evaluating the effectiveness of web technologies, including emotions (Gilmore \& Warren, 2007), teachers' attitudes toward information technology (Grainger \& Tolhurst, 2005), plagiarism (Harris \& Rea, 2009), students' perception of information technology (Hikmet et al., 2008), motivation and group interaction (Hazari et al., 2009), students' different styles and expectations (Williams \& Chinn, 2009), students' physical distance, their lack of direct responses, and the lack of restrictions over assessments (Halawi, Pires, \& McCarthy, 2009). "There is a need to take stock of information and communications technologies investments in schools to assess whether they have been effective, rather than the results of well-intentioned administrators' jumping onto the information and communication technologies bandwagon" (Hikmet et al., 2008: p. 128). There are also many factors that present challenges in faculty sustainability, including faculty development programs (Alsaady, 2007; Baasandorj, 2010; Yates, 2010); issues and barriers (Chuang, 2004); perceptions 
of onsite versus online teaching (Fillion et al., 2006); perceptions (Sahin \& Thompson, 2006); and constructs that affect online teaching (Velez, 2010).

\section{Statement of the Problem}

The problem with advanced technological utilization by faculty in higher education is that higher education institutions are installing state of the art technology into classrooms and faculty members are expected to infuse this technology into their teaching, but only about $20 \%$ of faculty members feel that they are prepared to comply (Chuang, 2004). Internet usage among 18 - 29 years old college students is at a staggering $93 \%$ and " $44 \%$ of the nearly 53 million Internet users produce and share digital content online" (Weyant \& Gardner, 2010: p. 68). Not only are these college students ahead of the faculty when it comes to technical skills and utilization, but the organizations that are waiting for these students to graduate so they can employ them are expecting familiarity of Web 2.0 technologies (Weyant \& Gardner, 2010).

\section{Purpose of the Study}

The purpose of this study was to examine faculty members' perception of Web 2.0 technologies on teaching and learning in higher education compared to traditional classroom teaching methods in programs at a higher education institutions to establish if relationships prevailed in their delivery of courses through the use of Web 2.0 technologies compared with traditional classroom delivery of courses: their overall satisfaction, the level of faculty development programs available, and their perceived effectiveness and impact of faculty development and issues and barriers affecting technology integration. This study also examined the influence of gender, age, and employment status on faculty members' perceptions of Web 2.0 technologies on teaching and learning in higher education compared to traditional classroom teaching methods.

\section{Research Questions}

The primary research question for this study was:

To what extent do faculty members teaching college courses utilizing Web 2.0 technologies perceive that this method is a practical alternative to the traditional classroom method?

The following secondary questions were asked to support the primary research question stated above:

Question 2: To what extent do faculty members perceive that there is an adequate level of development programs available to create their course content utilizing Web 2.0 technologies?

Question 3: To what extent do faculty members perceive that the faculty development programs affecting technology integration are effective?

Question 4: To what extent do faculty members perceive that the impact of the barriers affecting technology integration is hindering their ability to utilize Web 2.0 technologies?

Question 5: Is there a difference in male and female faculty members' perceptions regarding their use of Web 2.0 technologies in their courses?

Question 6: Is there a difference in faculty members' perceptions regarding their use of Web 2.0 technologies in their courses respective to their age?

Question 7: Is there a difference in faculty members' percep- tions regarding their use of Web 2.0 technologies in their courses respective to their employment status?

\section{Significance of the Study}

With technology continuing to expand at a rapid rate and being ever changing (Rockart et al., 1996), just keeping up with it can be a daunting task in itself. "In some schools, the Internet and other technologies are being integrated at the institutional level; with a student's complete academic experience-from application through registration and tuition payment, to final examination and course grade-occurring on-line" (Gottwald, 2005: p. 2). The rapidly growing technology infrastructure at institutions of higher education to meet the instructional and research needs of faculty, staff, and students (Alsaady, 2007) is making faculty development with the use of technology a requirement. Between 2002 and 2006, online learning increased by $21.5 \%$ while the entire higher education student body only increased by $1.5 \%$ (Yates, 2010). These are pretty alarming statistics and with Web 3.0 moving fast upon us, institutions of higher education need to put improving teaching and learning through the use of Web 2.0 technologies as a priority in their strategic plans so faculty members can learn not only how to use Web 2.0 technologies, but how to successfully infuse Web 2.0 technologies into their curriculums to improve learning.

In order for faculty members' to remain competitive and sustainable in this digital age, professional development on the use of technology and how to infuse technology into course curricula is a requirement. Identifying the aspects of effectiveness and potential impacts of faculty development will recognize areas of success and failure and will contribute to improving the content of faculty development (Al-Washahi, 2007). The results are expected to empower the faculty members to actively infuse technology into their curriculum and classroom, thus providing a state of the art experience for the student community at institutions of higher education.

Li and Pitts (2009) state that "the use of Web-based learning technologies has increased dramatically over the past decade providing new opportunities and avenues for students to interact with their professors virtually using computer-mediated communication technologies" (p. 175). An increasing number of institutions on higher education are relying on Web 2.0 technologies for teaching and learning purposes. Barnett (2008) cautions, however, that "beyond the use of new online tools by individual academics, an adoption of the philosophies, stakeholder expectations and development concepts of Web/HE 2.0 is likely to prove far more difficult for HE institutions at a strategic level" (p. 50).

It is often the case that institutions of higher education are incorporating state of the art technology into every teaching and learning facility on campus and online, but it may also be the case that the faculty members are not fully integrating the technology into their curriculums. From the students' perspective, the millennial generation grew up with technology. Lee (2010) states that "technology has had the most dramatic influence on the youngest members of society, also known as the millennial generation" (p. 3). The needs of the student population in institutions of higher education are rapidly evolving into the most technological advanced generation and if institutions and faculty members want to remain competitive must infuse technology with curriculums and continuously improve the technological offerings. Barrett (2008) posits that "higher edu- 
cation in particular is hence playing catch-up, as those it seeks to educate increasingly arrive with the content sharing and service skills that those teaching them and managing that teaching have often not yet fully understood" (p. 48).

\section{Definition of Terms}

\section{Avatar}

An avatar "is a three dimensional cartoon character that interacts with other objects and avatars in Second Life" (Lee, 2010: p. 19). An avatar is a virtual representation of the person creating it.

\section{Blogs}

A blog is similar to an online diary. It is a webpage "consisting of brief paragraphs of opinion, information, personal diary entries, or links, called posts, arranged chronologically with the most recent first, in the style of an online journal" (Anderson, 2007: p. 7).

\section{Facebook}

Facebook, initially created for college student synergy, is an online network that allows people to have personal page and grants them the ability to stay in touch with other people (Fuller, 2011). The personal page includes personal information, photos, videos, text, and a 'wall' for friends to post information on (McCarthy, 2010). As a user, you can add friends, create groups and events (that you can invite friends to), create networks which link the user to professional and higher education facebook sites.

\section{Hybrid Courses}

Hybrid is the term used to describe educational courses delivered through a mixture of traditional face-to-face and online teaching methods.

\section{Online Courses}

Online is the term used to describe educational courses delivered through the Internet.

\section{Podcast}

A Podcast is an audio or video file created for use on mp3 players or on a computer (Baker, Harrison, Thornton, \& Yates, 2010).

\section{Second Life}

Second Life is a three-dimensional computerized environment where members can socialize, hold virtual meetings, or conduct transactions online (Wang \& Braman, 2009). Second Life is the largest virtual world with 15 million registered accounts in 2008 (Harris \& Rea, 2009).

\section{Skype}

Skype is a synchronous voice and video communication tool (Newman, 2007).

\section{Traditional Face-to-Face Courses}

Traditional face-to-face is the term used to describe educational courses delivered face-to-face in the classroom at the educational institution.

\section{Twitter}

Twitter is a free micro-blogging application that allows for quick exchanges of thoughts, ideas, and information, which are delivered as messages up to 140 characters each (Wankel, 2009).

\section{Virtual Worlds}

A virtual world is a "computer simulated environment that enables users to interact with each other without geographical confines" (Harris \& Rea, 2009: p. 138). Real people are characterized by avatars (a virtual 'you') and meet, interact and exchange ideas with each other at virtual locations.

\section{Web 2.0}

Web 2.0 is a service "built using the building blocks of the technologies and open standards that underpin the Internet and the web" (Anderson, 2007: p. 7). These services include blogs, wikis, browsers with plugins, social networking, multimedia sharing, content syndication, podcasting and content tagging services (think of tagging a person in a photo to identify their name).

\section{Wikis}

Wikis are a "type of Web site that makes it easy for users to contribute and edit text content and graphics without any knowledge of Web page development or programming techniques" (Laudon \& Laudon, 2009: p. 66). Wikipedia is one of the best (and biggest) examples of a Wiki.

\section{YouTube}

YouTube "is the most popular and widely accepted video sharing website on the Internet" (Lee, 2010: p. 23).

\section{Web 2.0 Tools}

\section{Blogs}

The Pew Internet and American Life Project reported in 2009 the usage of blogs in the following way: " $32 \%$ of all American adults go online to read someone else's blog; $15 \%$ work on someone else's webpage or blog; and $11 \%$ create or work on their own online journal or blog" (Weyant \& Gardner, 2010: p. 68). Faculty are infusing blogs into their course curriculums for a variety of purposes, including syllabi distribution, digital portfolios, collaborative writing, and discussion group assignments (Weyant \& Gardner, 2010). Alexander (2008) argues that blogs are the "centerpiece" to the organization of Web 2.0 because "the simplicity of creating and updating blogs empowers readers to write, evoking the phrase read/write Web" (p. 152).

\section{Facebook}

Facebook, initially created in 2004 for college student interaction by Harvard college student Mark Zuckerberg (Fuller, 2011), became widely available one year later. In late 2007 , Facebook started a fan page feature that permitted universities to post information under their university name on Facebook (Fuller, 2011), and "by January 2008, 420 universities were using the fan page feature" (p. 49). This means that any user of Facebook can become a fan of any or all of the universities featured on Facebook. For universities, this can be a huge marketing opportunity because "the current social networking platform of choice among students in higher education is Facebook" (Wankel, 2009: p. 252). Facebook statistics suggest that 
there were $845,000,000$ monthly active users at the end of December 2011, 483,000,000 daily active users on average in December 2011, more than 425,000,000 monthly active users who used Facebook mobile products in December 2011, and available in more than 70 languages (Facebook, 2012).

By utilizing Facebook, faculty members can use the same tool that the students are already using to do other collaboration for course collaboration rather than making them log on to a separate course collaboration tool or website (Lee, 2010). Wankel (2009) furthers this discussion by stating that:

The uses of Facebook by management instructors include the ability to provide an attractive interactive venue, such as a Facebook group, for students to post threaded discussions on course-related material and activities, as well as reply to other student posting creating the sort of interactivity expected by accreditation agencies, most particularly online courses (p. 252).

In 2009, a Facebook assessment was done at the University of Adelaide in Australia with a first year design elective course. In this 6-week program, 120 students including 27 international students were enrolled in the course and participated in the assessment that involved a blended environment of both online engagements and face-to-face engagements (McCarthy, 2010). "The 2009 study indicated that the blending of real and virtual environments increased peer interaction and academic engagement, two key factors in a positive first year experience" (McCarthy, 2009: p. 738). McCarthy also notes that the increased collaboration between resident and international students was one of the most gratifying features of the online learning environment with Facebook.

\section{Podcast}

Podcasting was originally designed for audio files through the use of the Apple iPod but was enhanced to include video files when the video enabled iPods appeared on the market (Baker et al., 2010). Podcasts can be downloaded and viewed through the use of any mp3 device or computer. "The basic elements required to initiate a Podcasting program consist of a personal computer, microphone, audio editing software (available at no charge from Audacity.com), web server and a website" (Baker et al., 2010: p. 9).

A study was conducted by Baker et al. (2010) with an aviation class at a university in Florida to assess the benefits of using podcasting in a class. The 29 students in the class had access to four different podcasts that were available through the course website. Each podcast was a summary of four subjects that previous students had difficulty in understanding. The 29 students were given a quiz made up of questions from the Federal Aviation Administration (FAA) question bank and the results were compared to the results from the previous year where students did not have access to podcasts. The results proved that there was no difference between the test scores from the students who did have access to the podcasts and from the students who did not have access to the podcasts.

\section{Second Life}

Second Life, a desktop virtual reality application, "is a threedimensional (3D) electronic environment where members can socialize, hold virtual meetings, or conduct economic transactions" (Wang \& Braman, 2009: p. 235). Second Life is an application that is downloaded to a person's computer in order to extract the three dimensional graphics (Lee, 2010). Second Life is composed of islands that can be purchased and owned by people; on each island, the owners can do anything their creative mind or budget allows (Lee, 2010). Two significant features of learning in Second Life are that students are "often more motivated and less distracted than when they are placed in a traditional classroom" (Lee, 2010: p. 36) and that "the simulations tend to be more relevant to student when learning about real world situations" (p. 36).

\section{Skype}

The most influential feature of Skype is the ability to provide synchronous video feed during calls (Newman, 2007). "Using Skype, students can contact an instructor for help anytime the instructor is logged on to his or her computer. With this synchronous form of communication in both audio and visual formats, instructors have the ability to talk with and see students anytime both parties are connected in the Skype application" (Newman, 2007: pp. 27-28). Based on a survey of 221 students, the addition of Skype did not have a significant effect on student perceptions of online communications, online learning, or online community (Newman, 2007). Newman (2007: p. 78) points out that "the majority of the students indicated their enthusiasm and willingness to use a synchronous communication tool, yet they optioned not to use it or did so very little"). This could have been due to the fact that students had to have microphones and speakers or headsets, so if they did not own these they considered it hassle to go check the equipment out and install it on the computer they were using (Newman, 2007).

\section{Twitter}

Twitter is being utilized by colleges and universities as a chat service with current and potential students and also to improve awareness of campus events (Fuller, 2011). It can also be utilized to allow of network of users to add to an unstructured collaboration of ideas, links and resources (Wankel, 2009). "In a large class section of perhaps hundreds of learners, tweeting enables an immense amount of interactivity, ideally enriching the session in which it occurs" (Wankel, 2009: p. 254). Professors at Marquette University in Wisconsin utilize Twitter to promote the development of listening and classroom community environment, information gathering, multi-tasking, writing skills, and attention skills and have reported an increase in communication with students with the use Twitter (Wenkel, 2009).

\section{Wiki}

Faculty are infusing wikis into their course curriculums for a variety of purposes, including collaborative writing, posting of class notes, project brainstorming, and as a course management system (Weyant \& Gardner, 2010). "Wikis support the constructivist, collaborative learning models by engaging students in the learning process" (Weyant \& Gardner, 2010: p. 70). The largest and most well-known wiki is Wikipedia (Nicolaou, 2009). Nicolaou (2009) posits that:

Wikipedia holds millions of articles in approximately 250 languages with more than two million pages in English. There are currently more than 75,000 active contributors to Wikipedia articles, while tens of thousands of edits are made daily to enhance the knowledge help by this online encyclopedia (p. 26).

\section{YouTube}

"YouTube provides colleges and universities a free mecha- 
nism for sharing recruiting videos" (Fuller, 2011: p. 50). YouTube is the standard for video streaming on the Internet (Lee, 2010) and instructors can use this as a tool for students to upload the videos as homework assignments. Video streaming is also available via Facebook, and both can easily be done with today's smart phones.

\section{Research Design}

This study used a nonexperimental, quantitative descriptive research design to investigate faculty members' perception of Web 2.0 technologies on teaching and learning in higher education compared to traditional classroom teaching methods. Quantitative techniques, as stated by Swanson and Holton (2005), "are particularly strong at studying large groups of people and making generalizations from the sample being studied to broader groups beyond that sample" (p. 30). This design was suitable for this research because the researcher had no control or influence over the variables. Cooper and Schindler (2008) posit that with nonexperimental researcher, "the researcher is limited to holding factors constant by judicious selection of subjects according to strict sampling procedures and by statistical manipulation of findings" (p. 143).

\section{Sample}

Participants for this study included full-time and part-time faculty members teaching at a public university in the United States, with the following selected attributes:

- $\quad$ Industry = Education;

- Job Function = Educator;

- $\quad$ Education Level = Graduate Degree;

- Employment = Employed Part Time, Employed Full Time;

- Age $=20-100+$;

- Country = USA.

Of the 1207 respondents who were willing to participate in the survey, 988 or $81.9 \%$ of them were disqualified because they were not a part time or full time faculty member teaching in a public university in the United States and $18.1 \%$ or 219 of the respondents were eligible to participate in the survey based on the selected criteria noted above. Of the 219 surveys received, 41 surveys were deleted because of missing data. A total of 178 or $81.3 \%$ of the surveys were considered usable because the respondents participated in and actually completed the survey.

\section{Setting}

Zoomerang, an online survey service affiliated with the online survey tool SurveyMonkey, was the setting this study. Zoomerang allows researchers to select an online panel of participants based on particular attributes set by the researcher.

\section{Instrumentation}

The instrument that was utilized for this research was an online survey that was designed and created by the researcher. Advantages of an online survey include the unit cost of data collection is low, the possibility for high speed of returns, all of the benefits of a self-administered instrument can be realized, all of the benefits of a computer-assisted instrument can be realized, and they provide time for thoughtful answers (Fowler, 2009). The online survey was created through SurveyMonkey.
SurveyMonkey, an online survey tool that has been available since 1999, was appropriate for this type of research as it allowed the researcher to create her own online survey using custom templates, the researcher obtained descriptive statistics on the results, and the results were downloaded into a database for additional data analysis (Creswell, 2009).

The survey was created following the five guiding principles of self-administered surveys: surveys should be self-explanatory, restricted to closed answers, the question forms should be few in number, laid out in a manner that is clear, and provide redundant information to make everything simple (Fowler, 2009). The survey was divided into three sections. The first section collected data on demographic information from the faculty members including age, gender, employment status, number of years working in higher education, how their courses are taught (face-to-face, hybrid, or online), and information on their work and personally owned computers. The second section of the survey listed current Web 2.0 technologies (Blogs, Facebook, Podcast, Second Life, Skype, Twitter, Wiki, YouTube) and the participant was asked to rate their proficiency level towards each technology on a 5 -point Likert scale $(1=$ expert, $5=$ proficient). The third section was a sequence of optimistic statements regarding faculty members' perceptions on whether or not teaching college courses utilizing Web 2.0 technologies was a practical alternative to the traditional classroom method. The participants were asked to match their level of agreement on a 5 -point Likert scale $(1=$ strongly disagree and $5=$ strongly agree).

\section{Data Collection}

The data was collected via an online survey, created through SurveyMonkey. Once approval was received from the SurveyMonkey Project Management team, the survey launched and data collection automatically began. In order for respondents to be eligible to begin the survey, they must have the following attributes:

- $\quad$ Industry = Education;

- Job Function = Educator;

- Education Level = Graduate Degree;

- Employment = Employed Part Time, Employed Full Time;

- $\quad$ Age $=20-100+$;

- Country = USA.

When respondents began the survey, the first page included the wording from the initial email to potential participants which explained the purpose of the research study, that they have been selected to participate in the research study, the procedures, and that their professional experience at their University will be invaluable to this particular research study. As the level of granularity on the available attribute selections within SurveyMonkey did not allow for ensuring that the participants were part time or full time faculty members employed at a public university in the United States, a screening question was included at the bottom of this page with skip logic that would automatically disqualify a respondent when their answer to the answer was no.

Respondents who answered yes to the question were sent to the next page which included the wording from the informed consent form. The consent form explained the benefits and risks, the voluntary participation, confidentiality statement, and provided contact information for the researcher if the participants had any further questions. If the respondent read and fully un- 
derstood the consent form and agreed to voluntarily participate as a subject in the research, they were able to access the survey by simply clicking the button labeled next. Once each survey was submitted by the participant, it was automatically saved in the SurveyMonkey database. SurveyMonkey notified the researcher once the project received the number of expected responses and the project was labeled as complete by SurveyMonkey. No further action needed to be taken by the participants.

\section{Results \\ Description of Participants}

The description of participants was defined through Section 1 of the online survey which included 13 questions that became the independent scale variables and one qualifying question to determine the eligibility of the respondent which was also an independent scale variable. Of the 1207 respondents who were willing to participate in the survey, 988 or $81.9 \%$ of them were disqualified because they were not a part time or full time faculty member teaching in a public university in the United States and $18.1 \%$ or 219 of the respondents were eligible to participate in the survey based on the selected criteria noted above. Of the 219 surveys received, 42 surveys were deleted because of missing data. A total of 177 or $80.8 \%$ of the surveys were considered usable because the respondents participated in and actually completed the survey. These statistics are defined in Table 1 .

Survey Question 1 asked the participants to select their gender. Table 2 displays the results.

Of the 177 valid responses, more than half of the participants were male with 96 or $54.2 \%$ being male and 81 or $45.8 \%$ being female. Survey Question 2 asked the participant to select the category that includes their age. The results are displayed in Table 3.

The majority of the faculty members who participated in this research study were in the age range of 50 - 59 years old $(25.4 \%)$ and 30 - 39 years old $(25.4 \%)$; the minority of the faculty members who participated were in the age range of 70 years and older $(5.1 \%)$ and between $20-29$ years old $(9.0 \%)$.

Table 1.

Frequency table - qualifying question to determine if participants are part time or full time faculty members teaching at a public university in the United States.

\begin{tabular}{cccccc}
\hline & & Frequency & Percent & Valid Percent & Cumulative Percent \\
\hline \multirow{4}{*}{ Valid } & Yes & 219 & 18.1 & 18.1 & 18.1 \\
& No & 988 & 81.9 & 81.9 & 100.0 \\
& Total & 1207 & 100.0 & 100.0 & \\
\hline
\end{tabular}

Table 2.

Frequency table-gender.

\begin{tabular}{cccccc}
\hline & & Frequency & Percent & Valid Percent & $\begin{array}{c}\text { Cumulative } \\
\text { Percent }\end{array}$ \\
\hline \multirow{4}{*}{ Valid } & Male & 96 & 8.0 & 54.2 & 54.2 \\
& Female & 81 & 6.7 & 45.8 & 100.0 \\
& Total & 177 & 14.7 & 100.0 & \\
Missing & System & 1030 & 85.3 & & \\
\multicolumn{2}{c}{ Total } & 1207 & 100.0 & & \\
\hline
\end{tabular}

Table 3.

Frequency table-age.

\begin{tabular}{|c|c|c|c|c|c|}
\hline & & Frequency & Percent & $\begin{array}{c}\text { Valid } \\
\text { Percent }\end{array}$ & $\begin{array}{c}\text { Cumulative } \\
\text { Percent }\end{array}$ \\
\hline & $20-29$ & 16 & 1.3 & 9.0 & 9.0 \\
\hline & $30-39$ & 45 & 3.7 & 25.4 & 34.5 \\
\hline & $40-49$ & 28 & 2.3 & 15.8 & 50.3 \\
\hline \multirow[t]{4}{*}{ Valid } & $50-59$ & 45 & 3.7 & 25.4 & 75.7 \\
\hline & $60-69$ & 34 & 2.8 & 19.2 & 94.9 \\
\hline & $70+$ & 9 & .7 & 5.1 & 100.0 \\
\hline & Total & 177 & 14.7 & 100.0 & \\
\hline Missing & System & 1030 & 85.3 & & \\
\hline \multicolumn{2}{|c|}{ Total } & 1207 & 100.0 & & \\
\hline
\end{tabular}

Survey Question 3 asked the participants to select the number of years they have been teaching in higher education. The results can be found in Table 4 .

The number of years that the faculty members have been teaching in higher education appeared on both ends of the spectrum with the majority of responses falling between $1-5$ years $(26.0 \%)$ or $21+$ years $(24.9 \%)$. The minority of responses fell between 16 - 20 years (12.4\%). Survey Question 4 asked the participants to select the number of years they have been teaching at their University. The results can be seen in Table 5.

When the faculty members were asked how many years they had been teaching at their university, the majority of them (68 or $38.4 \%$ ) had been teaching at their university for $1-5$ years while 10 or $5.6 \%$ of the faculty members had been teaching at their university for 16 - 20 years. Survey Question 5 asked the participants to select their current employment status within the University. These results are indicated by Table 6.

Of the 177 faculty members who participated in the research study, almost half (86 or $48.6 \%$ ) were adjuncts, while 37 or $20.9 \%$ were professors, 25 or $14.1 \%$ were assistant professors, and 24 or $13.6 \%$ were associate professors. The minority of the participants selected chairperson (3 or 1.7\%), assistant dean (1 or $.6 \%$ ) or associate dean (1 or .6\%).

Survey Question 6 asked the participants to select the level of courses they taught (undergraduate, graduate or both). The results can be found in Table 7 .

The majority of the faculty members taught undergraduate courses $(113$ or $63.8 \%)$; 15 or $8.5 \%$ taught graduate courses; and 49 or $27.7 \%$ taught both undergraduate and graduate courses. Survey Question 7 asked the participants to select the method of teaching they utilize (traditional face-to-face, online, hybrid, or all of the above). The results are displayed in Table 8.

The majority of the participants (111 or $62.7 \%$ ) taught traditional face-to-face courses, 16 or $9.0 \%$ taught online courses, 5 or $2.8 \%$ taught hybrid courses, and a quarter of the participants (45 or $25.4 \%$ ) taught traditional face-to-face, online and hybrid courses. Survey Question 8 asked the participants to select their preferred method of teaching. The results can be found in Table 9 .

The majority of the participants (114 or $64.4 \%$ ) preferred to teach traditional face-to-face courses, 22 or $12.4 \%$ preferred to teach hybrid courses, 15 or $8.5 \%$ preferred to teach online, and 26 or $14.7 \%$ did not have a preference. Survey Question 9 asked the participants if they had a personal computer. Table 10 displays the results.

Almost all of the faculty participants had a personal computer (172 or $97.2 \%)$ and 5 or $2.8 \%$ of the faculty members did 
Table 4.

Frequency table - number of years teaching in higher education.

\begin{tabular}{|c|c|c|c|c|c|}
\hline & & Frequency & Percent & $\begin{array}{c}\text { Valid } \\
\text { Percent }\end{array}$ & $\begin{array}{c}\text { Cumulative } \\
\text { Percent }\end{array}$ \\
\hline \multirow{5}{*}{ Valid } & $1-5$ & 46 & 3.8 & 26.0 & 26.0 \\
\hline & $6-10$ & 38 & 3.1 & 21.5 & 47.5 \\
\hline & $11-15$ & 27 & 2.2 & 15.3 & 62.7 \\
\hline & $16-20$ & 22 & 1.8 & 12.4 & 75.1 \\
\hline & $21+$ & 44 & 3.6 & 24.9 & 100.0 \\
\hline \multirow{3}{*}{$\begin{array}{r}\text { Missing } \\
\text { T }\end{array}$} & Total & 177 & 14.7 & 100.0 & \\
\hline & System & 1030 & 85.3 & & \\
\hline & Total & 1207 & 100.0 & & \\
\hline
\end{tabular}

Table 5.

Frequency table - number of years teaching at the university.

\begin{tabular}{|c|c|c|c|c|c|}
\hline & & Frequency & Percent & $\begin{array}{c}\text { Valid } \\
\text { Percent }\end{array}$ & $\begin{array}{c}\text { Cumulative } \\
\text { Percent }\end{array}$ \\
\hline \multirow{5}{*}{ Valid } & $1-5$ & 68 & 5.6 & 38.4 & 38.4 \\
\hline & 6-10 & 40 & 3.3 & 22.6 & 61.0 \\
\hline & $11-15$ & 30 & 2.5 & 16.9 & 78.0 \\
\hline & $16-20$ & 10 & .8 & 5.6 & 83.6 \\
\hline & $21+$ & 29 & 2.4 & 16.4 & 100.0 \\
\hline \multirow{3}{*}{ Missing } & Total & 177 & 14.7 & 100.0 & \\
\hline & System & 1030 & 85.3 & & \\
\hline & Total & 1207 & 100.0 & & \\
\hline
\end{tabular}

Table 6.

Frequency table - current employment status within the university.

\begin{tabular}{cccccc}
\hline & & Frequency & Percent & \multicolumn{2}{c}{ Valid } \\
Percent & Cumulative & Percent \\
\hline \multirow{6}{*}{ Valid } & Adjunct & 86 & 7.1 & 48.6 & 48.6 \\
& Assistant Professor & 25 & 2.1 & 14.1 & 62.7 \\
& Associate Professor & 24 & 2.0 & 13.6 & 76.3 \\
& Professor & 37 & 3.1 & 20.9 & 97.2 \\
& Chairperson & 3 & .2 & 1.7 & 98.9 \\
& Assistant Dean & 1 & .1 & .6 & 99.4 \\
& Associate Dean & 1 & .1 & .6 & 100.0 \\
& Total & 177 & 14.7 & 100.0 & \\
\multirow{4}{*}{ Missing } & System & 1030 & 85.3 & & \\
& Total & 1207 & 100.0 & & \\
\hline
\end{tabular}

Table 7.

Frequency table-level of courses taught.

\begin{tabular}{cccccc}
\hline & & Frequency & Percent & $\begin{array}{c}\text { Valid } \\
\text { Percent }\end{array}$ & $\begin{array}{c}\text { Cumulative } \\
\text { Percent }\end{array}$ \\
\hline \multirow{4}{*}{ Valid } & Under graduate & 113 & 9.4 & 63.8 & 63.8 \\
& Graduate & 15 & 1.2 & 8.5 & 72.3 \\
& Both & 49 & 4.1 & 27.7 & 100.0 \\
& Total & 177 & 14.7 & 100.0 & \\
\multirow{4}{*}{ Missing } & System & 1030 & 85.3 & & \\
& Total & 1207 & 100.0 & & \\
\hline
\end{tabular}

Table 8.

Frequency table - method of teaching courses.

\begin{tabular}{|c|c|c|c|c|c|}
\hline & & Frequency & Percent & $\begin{array}{c}\text { Valid } \\
\text { Percent }\end{array}$ & $\begin{array}{c}\text { Cumulative } \\
\text { Percent }\end{array}$ \\
\hline \multirow{4}{*}{ Valid } & $\begin{array}{l}\text { Traditional } \\
\text { face-to-face }\end{array}$ & 111 & 9.2 & 62.7 & 62.7 \\
\hline & Online & 16 & 1.3 & 9.0 & 71.8 \\
\hline & Hybrid & 5 & .4 & 2.8 & 74.6 \\
\hline & All of the above & 45 & 3.7 & 25.4 & 100.0 \\
\hline \multirow{3}{*}{ Missing } & Total & 177 & 14.7 & 100.0 & \\
\hline & System & 1030 & 85.3 & & \\
\hline & Total & 1207 & 100.0 & & \\
\hline
\end{tabular}

Table 9.

Frequency table - teaching method preference.

\begin{tabular}{|c|c|c|c|c|c|}
\hline & & Frequency & Percent & $\begin{array}{l}\text { Valid } \\
\text { Percent }\end{array}$ & $\begin{array}{c}\text { Cumulative } \\
\text { Percent }\end{array}$ \\
\hline & $\begin{array}{l}\text { Traditional } \\
\text { face-to-face }\end{array}$ & 114 & 9.4 & 64.4 & 64.4 \\
\hline \multirow{3}{*}{ Valid } & Hybrid & 22 & 1.8 & 12.4 & 76.8 \\
\hline & Online & 15 & 1.2 & 8.5 & 85.3 \\
\hline & No preference & 26 & 2.2 & 14.7 & 100.0 \\
\hline \multirow{3}{*}{ Missing } & Total & 177 & 14.7 & 100.0 & \\
\hline & System & 1030 & 85.3 & & \\
\hline & Total & 1207 & 100.0 & & \\
\hline
\end{tabular}

Table 10.

Frequency table — personal home computer.

\begin{tabular}{|c|c|c|c|c|c|}
\hline & & Frequency & Percent & $\begin{array}{c}\text { Valid } \\
\text { Percent }\end{array}$ & $\begin{array}{c}\text { Cumulative } \\
\text { Percent }\end{array}$ \\
\hline & Yes & 172 & 14.3 & 97.2 & 97.2 \\
\hline \multirow[t]{2}{*}{ Valid } & No & 5 & .4 & 2.8 & 100.0 \\
\hline & Total & 177 & 14.7 & 100.0 & \\
\hline Missing & System & 1030 & 85.3 & & \\
\hline \multicolumn{2}{|c|}{ Total } & 1207 & 100.0 & & \\
\hline
\end{tabular}

not have a personal computer. Survey Question 10 asked the participants if they had a computer issued from the University. The results of this question are displayed in Table 11.

Based on the results from Table 11, over half of the faculty participants ( 95 or $53.7 \%$ ) had a computer issued from the university, and 82 or $46.3 \%$ of the faculty members did not have a computer issued by the University. Survey Question 11 asked the participants how technically proficient they considered themselves to be. Table 12 shows the results.

Based on the results from Table 12, 66 (37.3\%) of the faculty members indicated that they were moderately proficient, 39 or $22 \%$ of the faculty members indicated that they were proficient and somewhat proficient, 29 or $16.4 \%$ indicated they were expert, and 4 or $2.3 \%$ indicated that they were not proficient. Survey Question 12 asked the participants to select how technically proficient they considered themselves to be when specifically talking about Web 2.0 technologies that their university offers. The results are reflected in Table 13.

Of the 177 responses, 55 or $31.1 \%$ of the faculty members rated themselves as somewhat proficient while 45 or $25.4 \%$ of the faculty members rated themselves as proficient. The difference between moderately proficient and proficient was only a matter of 7 faculty members, however, only 13 or $7.3 \%$ of the 
Table 11.

Frequency table - university issued computer.

\begin{tabular}{cccccc}
\hline & & Frequency & Percent & $\begin{array}{c}\text { Valid } \\
\text { Percent }\end{array}$ & $\begin{array}{c}\text { Cumulative } \\
\text { Percent }\end{array}$ \\
\hline \multirow{3}{*}{ Valid } & Yes & 95 & 7.9 & 53.7 & 53.7 \\
& No & 82 & 6.8 & 46.3 & 100.0 \\
& Total & 177 & 14.7 & 100.0 & \\
Missing & System & 1030 & 85.3 & & \\
\multicolumn{2}{c}{ Total } & 1207 & 100.0 & & \\
\hline
\end{tabular}

Table 12.

Frequency table- technical proficiency level.

\begin{tabular}{|c|c|c|c|c|c|}
\hline & & Frequency & Percent & $\begin{array}{c}\text { Valid } \\
\text { Percent }\end{array}$ & $\begin{array}{c}\text { Cumulative } \\
\text { Percent }\end{array}$ \\
\hline \multirow{5}{*}{ Valid } & Not Proficient & 4 & .3 & 2.3 & 2.3 \\
\hline & $\begin{array}{l}\text { Somewhat } \\
\text { Proficient }\end{array}$ & 39 & 3.2 & 22.0 & 24.3 \\
\hline & Proficient & 39 & 3.2 & 22.0 & 46.3 \\
\hline & $\begin{array}{l}\text { Moderately } \\
\text { Proficient }\end{array}$ & 66 & 5.5 & 37.3 & 83.6 \\
\hline & Expert & 29 & 2.4 & 16.4 & 100.0 \\
\hline \multirow{3}{*}{ Missing } & Total & 177 & 14.7 & 100.0 & \\
\hline & System & 1030 & 85.3 & & \\
\hline & Total & 1207 & 100.0 & & \\
\hline
\end{tabular}

Table 13.

Frequency table- technology proficiency level based on Web 2.0 technologies offered by the university.

\begin{tabular}{|c|c|c|c|c|c|}
\hline & & Frequency & Percent & $\begin{array}{c}\text { Valid } \\
\text { Percent }\end{array}$ & $\begin{array}{c}\text { Cumulative } \\
\text { Percent }\end{array}$ \\
\hline \multirow{5}{*}{ Valid } & Not Proficient & 26 & 2.2 & 14.7 & 14.7 \\
\hline & $\begin{array}{l}\text { Somewhat } \\
\text { Proficient }\end{array}$ & 55 & 4.6 & 31.1 & 45.8 \\
\hline & Proficient & 45 & 3.7 & 25.4 & 71.2 \\
\hline & $\begin{array}{l}\text { Moderately } \\
\text { Proficient }\end{array}$ & 38 & 3.1 & 21.5 & 92.7 \\
\hline & Expert & 13 & 1.1 & 7.3 & 100.0 \\
\hline \multirow{3}{*}{ Missing } & Total & 177 & 14.7 & 100.0 & \\
\hline & System & 1030 & 85.3 & & \\
\hline & Total & 1207 & 100.0 & & \\
\hline
\end{tabular}

faculty members rated themselves as an expert. Survey Question 13 asked the participants to select their best method of learning. The results can be found in Table 14.

The majority of the faculty members, 103 or $58.2 \%$, indicated that they learned best by doing, while 63 or $35.6 \%$ learned best by reading or watching. Only 11 or $6.2 \%$ of the faculty learned best by listening.

\section{Description of Ordinal Variables}

Sections 2 and 3 of the survey contain the dependent ordinal variables. Section 2 asked the faculty member to identify their current level of Web 2.0 technology use, from never to very often, at their university for instructional purposes. Survey Question 14 asked the participants to select their current level of utilizing Blogs for instructional purposes. The results are indicated in Table 15.

The majority of the faculty members have never utilized Blogs ( 75 or $42.4 \%$ ), 40 or $22.5 \%$ sometimes utilized Blogs, 36 or $20.3 \%$ rarely utilized Blogs, 23 or $13.0 \%$ often utilized Blogs, and 3 or $1.7 \%$ very often utilized Blogs. Survey Question 15 asked the participants to select their current level of utilizing
Facebook for instructional purposes. The results are indicated by Table 16 .

Half of the faculty members (90 or $50.8 \%$ ) never utilized Facebook for instructional purposes, while 28 of the faculty members have rarely utilized Facebook and 27 or $15.3 \%$ sometimes utilized Facebook. The minority of the faculty members have either often utilized Facebook (22 or $12.4 \%$ ) or very often utilized Facebook (10 or 5.6\%). Survey Question 16 asked the participants to select their utilization of Podcast for instructional purposes. The results of this question can be found in Table 17.

Table 14.

Frequency table — best method of learning.

\begin{tabular}{cccccc}
\hline \multirow{4}{*}{ Valid } & Frequency & Percent & $\begin{array}{c}\text { Valid } \\
\text { Percent }\end{array}$ & $\begin{array}{c}\text { Cumulative } \\
\text { Percent }\end{array}$ \\
\hline & $\begin{array}{c}\text { Reading or } \\
\text { watching }\end{array}$ & 63 & 5.2 & 35.6 & 35.6 \\
& Listening & 11 & .9 & 6.2 & 41.8 \\
& Doing & 103 & 8.5 & 58.2 & 100.0 \\
\multirow{4}{*}{ Missing } & Total & 177 & 14.7 & 100.0 & \\
\hline & System & 1030 & 85.3 & & \\
& Total & 1207 & 100.0 & & \\
\hline
\end{tabular}

Table 15.

Frequency table-Blogs utilization for instructional purposes.

\begin{tabular}{cccccc}
\hline & & Frequency & Percent & $\begin{array}{c}\text { Valid } \\
\text { Percent }\end{array}$ & $\begin{array}{c}\text { Cumulative } \\
\text { Percent }\end{array}$ \\
\hline \multirow{6}{*}{ Valid } & Never & 75 & 6.2 & 42.4 & 42.4 \\
& Rarely & 36 & 3.0 & 20.3 & 62.7 \\
& Sometimes & 40 & 3.3 & 22.6 & 85.3 \\
& Often & 23 & 1.9 & 13.0 & 98.3 \\
& Very Often & 3 & .2 & 1.7 & 100.0 \\
\multirow{4}{*}{ Missing } & Total & 177 & 14.7 & 100.0 & \\
& System & 1030 & 85.3 & & \\
& Total & 1207 & 100.0 & & \\
\hline
\end{tabular}

Table 16.

Frequency table-Facebook utilization for instructional purposes.

\begin{tabular}{|c|c|c|c|c|c|}
\hline & & Frequency & Percent & $\begin{array}{c}\text { Valid } \\
\text { Percent }\end{array}$ & $\begin{array}{c}\text { Cumulative } \\
\text { Percent }\end{array}$ \\
\hline & Never & 90 & 7.5 & 50.8 & 50.8 \\
\hline \multirow{4}{*}{ Valid } & Rarely & 28 & 2.3 & 15.8 & 66.7 \\
\hline & Sometimes & 27 & 2.2 & 15.3 & 81.9 \\
\hline & Often & 22 & 1.8 & 12.4 & 94.4 \\
\hline & Very Often & 10 & .8 & 5.6 & 100.0 \\
\hline \multirow{3}{*}{ Missing } & Total & 177 & 14.7 & 100.0 & \\
\hline & System & 1030 & 85.3 & & \\
\hline & Total & 1207 & 100.0 & & \\
\hline
\end{tabular}

Table 17.

Frequency table-Podcast utilization for instructional purposes.

\begin{tabular}{cccccc}
\hline & Frequency & Percent & $\begin{array}{c}\text { Valid } \\
\text { Percent }\end{array}$ & $\begin{array}{c}\text { Cumulative } \\
\text { Percent }\end{array}$ \\
\hline \multirow{4}{*}{ Valid } & Never & 86 & 7.1 & 48.6 & 48.6 \\
& Rarely & 28 & 2.3 & 15.8 & 64.4 \\
& Sometimes & 43 & 3.6 & 24.3 & 88.7 \\
& Often & 15 & 1.2 & 8.5 & 97.2 \\
& Very Often & 5 & .4 & 2.8 & 100.0 \\
Missing & Total & 177 & 14.7 & 100.0 & \\
Total & 1030 & 85.3 & & \\
\hline
\end{tabular}


The majority of the faculty members ( 86 or $48.6 \%$ ) have never utilized Podcast for instructional purposes, while 43 or $24.3 \%$ sometimes utilized Podcast, and 28 or $15.8 \%$ rarely utilized Podcast. Of the 177 participants, 15 or $8.5 \%$ often utilized Podcast and 5 or $2.8 \%$ very often utilized Podcast for instructional purposes. Survey Question 17 asked the participants how often they utilized Second Life for instructional purposes. The results of this question can be found in Table $\mathbf{1 8 .}$

The majority of the participants (141 or $79.7 \%$ ), have never utilized Second Life for instructional purposes, 15 or $8.5 \%$ of the participants have rarely utilized Second Life, 17 or $9.6 \%$ sometimes utilized Second Life and 4 or $2.3 \%$ often utilize Second Life. Survey Question 18 asked the participants how often they utilized Skype for instructional purposes. The results are indicated Table 19.

The majority of faculty members (91 or $51.4 \%$ ) have never utilized Skype for instructional purposes, while 35 or $19.8 \%$ have rarely utilized Skype, 33 or $18.6 \%$ sometimes utilized Skype, 15 or $8.5 \%$ often utilize Skype, and 3 or $1.7 \%$ very often utilize Skype. Survey Question 19 asked the participants how often they utilized Twitter for instructional purposes. The results can be found in Table $\mathbf{2 0}$.

Table 18.

Frequency table-Second Life utilization for instructional purposes.

\begin{tabular}{|c|c|c|c|c|c|}
\hline & & Frequency & Percent & $\begin{array}{c}\text { Valid } \\
\text { Percent }\end{array}$ & $\begin{array}{c}\text { Cumulative } \\
\text { Percent }\end{array}$ \\
\hline & Never & 141 & 11.7 & 79.7 & 79.7 \\
\hline \multirow{4}{*}{ Valid } & Rarely & 15 & 1.2 & 8.5 & 88.1 \\
\hline & Sometimes & 17 & 1.4 & 9.6 & 97.7 \\
\hline & Often & 4 & .3 & 2.3 & 100.0 \\
\hline & Total & 177 & 14.7 & 100.0 & \\
\hline \multirow[t]{2}{*}{ Missing } & System & 1030 & 85.3 & & \\
\hline & Total & 1207 & 100.0 & & \\
\hline
\end{tabular}

Table 19.

Frequency table-Skype utilization for instructional purposes.

\begin{tabular}{cccccc}
\hline & & Frequency & Percent & $\begin{array}{c}\text { Valid } \\
\text { Percent }\end{array}$ & $\begin{array}{c}\text { Cumulative } \\
\text { Percent }\end{array}$ \\
\hline \multirow{6}{*}{ Valid } & Never & 91 & 7.5 & 51.4 & 51.4 \\
& Rarely & 35 & 2.9 & 19.8 & 71.2 \\
& Sometimes & 33 & 2.7 & 18.6 & 89.8 \\
& Often & 15 & 1.2 & 8.5 & 98.3 \\
& Very Often & 3 & .2 & 1.7 & 100.0 \\
\multirow{4}{*}{ Missing } & Total & 177 & 14.7 & 100.0 & \\
& System & 1030 & 85.3 & & \\
& Total & 1207 & 100.0 & & \\
\hline
\end{tabular}

Table 20.

Frequency table-Twitter utilization for instructional purposes.

\begin{tabular}{cccccc}
\hline & & Frequency & Percent & $\begin{array}{c}\text { Valid } \\
\text { Percent }\end{array}$ & $\begin{array}{c}\text { Cumulative } \\
\text { Percent }\end{array}$ \\
\hline \multirow{6}{*}{ Valid } & Never & 126 & 10.4 & 71.2 & 71.2 \\
& Rarely & 21 & 1.7 & 11.9 & 83.1 \\
& Sometimes & 18 & 1.5 & 10.2 & 93.2 \\
& Often & 10 & .8 & 5.6 & 98.9 \\
& Very Often & 2 & .2 & 1.1 & 100.0 \\
\multirow{4}{*}{ Missing } & Total & 177 & 14.7 & 100.0 & \\
\hline & System & 1030 & 85.3 & & \\
\hline & Total & 1207 & 100.0 & & \\
\hline
\end{tabular}

The majority of the participants (126 or $71.2 \%$ ) have never utilized Twitter for instructional purposes, while 21 or $11.9 \%$ rarely utilized Twitter, and 18 or $10.2 \%$ of the faculty members sometimes utilized Twitter. The minority of the participants (2 or $1.1 \%$ ) very often utilizes Twitter, and 10 or $5.6 \%$ often utilize Twitter for instructional purposes. Survey Question 20 asked the participants how often they utilized Wikis for instructional purposes. The results can be found in Table 21.

Over half of the participants ( 92 or 52\%) have never utilized Wikis for instructional purposes, while 34 or $19.2 \%$ rarely utilize Wikis and 35 or $19.8 \%$ sometimes utilize Wikis. Of the 177 tot participants, 12 or $6.8 \%$ indicated that they often utilize Wikis and 4 or $2.3 \%$ indicated that they very often utilize Wikis for instructional purposes. Survey Question 21 asked the participants how often they utilized YouTube for instructional purposes. The results can be found in Table 22 .

The majority of the participants (71 or $40.1 \%$ ) indicated that they sometimes utilize YouTube for instructional purposes, while 44 or $24.9 \%$ have rarely utilized YouTube and 27 or $15.3 \%$ have never utilized YouTube for instructional purposes. The minority of the participants ( 9 or 5.1\%) indicated that they very often utilized YouTube and 25 or $14.7 \%$ indicated that they often utilize YouTube for instructional purposes. Descriptive statistics for the Web 2.0 technologies analyzed (Blogs, Facebook, Podcast, Second Life, Skype, Twitter, Wiki, and YouTube) can be found in Table 23.

In summary, Table 23 shows that the Web 2.0 technologies that are utilized the least out of all of the participants were Second Life with a mean of 1.3446 and Twitter with a mean of 1.5367. The Web 2.0 technologies utilized the most out of all of the participants was YouTube with a mean of 2.6949 and Blogs with a mean of 2.1130 .

Crosstablulation analyses were conducted to understand the impact of gender on the level of Web 2.0 technology utilization at the faculty members' university. Figure 1 shows the impact of gender on the level of Blog utilization at their respective university.

\section{Table 21.}

Frequency table-Wiki utilization for instructional purposes.

\begin{tabular}{cccccc}
\hline & & Frequency & Percent & $\begin{array}{c}\text { Valid } \\
\text { Percent }\end{array}$ & $\begin{array}{c}\text { Cumulative } \\
\text { Percent }\end{array}$ \\
\hline \multirow{6}{*}{ Valid } & Never & 92 & 7.6 & 52.0 & 52.0 \\
& Rarely & 34 & 2.8 & 19.2 & 71.2 \\
& Sometimes & 35 & 2.9 & 19.8 & 91.0 \\
& Often & 12 & 1.0 & 6.8 & 97.7 \\
& Very Often & 4 & .3 & 2.3 & 100.0 \\
\multirow{4}{*}{ Missing } & Total & 177 & 14.7 & 100.0 & \\
\hline & System & 1030 & 85.3 & & \\
& Total & 1207 & 100.0 & & \\
\hline
\end{tabular}

Table 22.

Frequency table-YouTube utilization for instructional purposes.

\begin{tabular}{|c|c|c|c|c|c|}
\hline & & Frequency & Percent & $\begin{array}{c}\text { Valid } \\
\text { Percent }\end{array}$ & $\begin{array}{c}\text { Cumulative } \\
\text { Percent }\end{array}$ \\
\hline \multirow{5}{*}{ Valid } & Never & 27 & 2.2 & 15.3 & 15.3 \\
\hline & Rarely & 44 & 3.6 & 24.9 & 40.1 \\
\hline & Sometimes & 71 & 5.9 & 40.1 & 80.2 \\
\hline & Often & 26 & 2.2 & 14.7 & 94.9 \\
\hline & Very Often & 9 & .7 & 5.1 & 100.0 \\
\hline \multirow{3}{*}{ Missing } & Total & 177 & 14.7 & 100.0 & \\
\hline & System & 1030 & 85.3 & & \\
\hline & Total & 1207 & 100.0 & & \\
\hline
\end{tabular}


Table 23.

Descriptive statistics of Web 2.0 technologies.

\begin{tabular}{|c|c|c|c|c|c|}
\hline & $\mathrm{N}$ & Minimum & Maximum & Mean & Std. Deviation \\
\hline Blogs & 177 & 1.00 & 5.00 & 2.1130 & 1.14748 \\
\hline Facebook & 177 & 1.00 & 5.00 & 2.0621 & 1.29316 \\
\hline Podcast & 177 & 1.00 & 5.00 & 2.0113 & 1.15300 \\
\hline Second Life & 177 & 1.00 & 4.00 & 1.3446 & .74612 \\
\hline Skype & 177 & 1.00 & 5.00 & 1.8927 & 1.08962 \\
\hline Twitter & 177 & 1.00 & 5.00 & 1.5367 & .96534 \\
\hline Wiki & 177 & 1.00 & 5.00 & 1.8814 & 1.08844 \\
\hline YouTube & 177 & 1.00 & 5.00 & 2.6949 & 1.05939 \\
\hline Valid N (listwise) & 177 & & & & \\
\hline
\end{tabular}

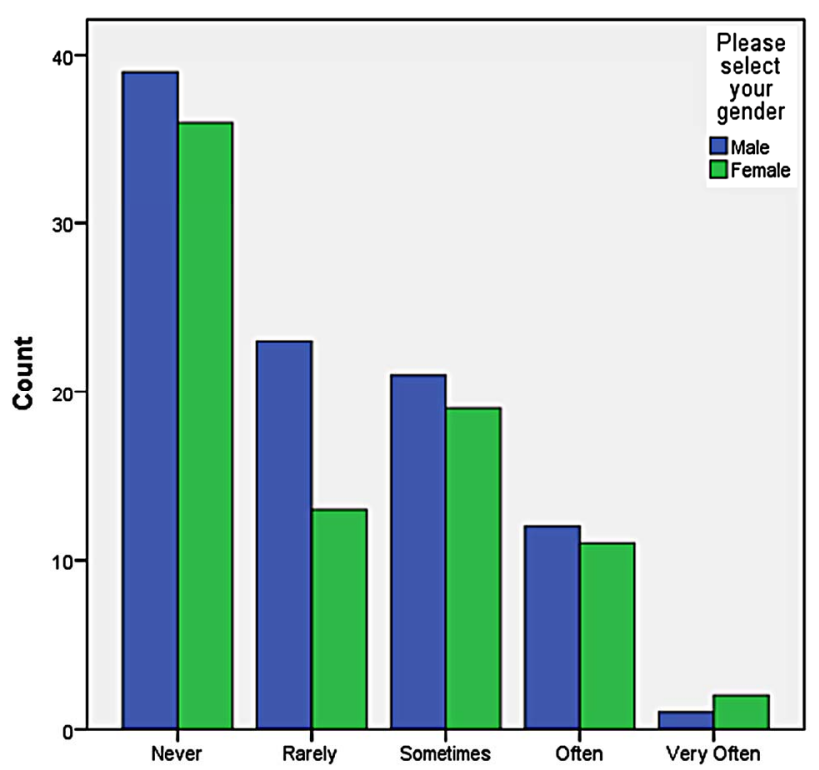

Figure 1.

Crosstabulation-Blog utilization for instructional purposes by gender.

Reviewing the results with highest count indicates that male faculty members had a higher count on the never utilizing Blog, rarely utilizing Blogs, sometimes utilizing Blogs, and often utilizing Blogs. Female faculty members had a higher count on very often utilizing Blogs for instructional purposes. Figure 2 shows the impact of gender on the level of Facebook utilization at their respective university.

Reviewing the results with highest count indicates that male faculty members had a higher count on never utilizing Facebook, rarely utilizing Facebook, and often utilizing Facebook for instructional purposes. Female faculty members had a higher count on sometimes utilizing Facebook, and very often utilizing Facebook for instructional purposes. Figure 3 shows the impact of gender on the level of Podcast utilization at their respective university.

Reviewing the results with highest count indicates that male faculty members had a higher count on never utilizing Podcast, rarely utilizing Podcast, sometimes utilizing Podcast, and very often utilizing Podcast for instructional purposes. Female faculty members had a higher count on often utilizing Podcast for instructional purposes. Figure 4 shows the impact of gender on the level of Second Life utilization at their respective university.

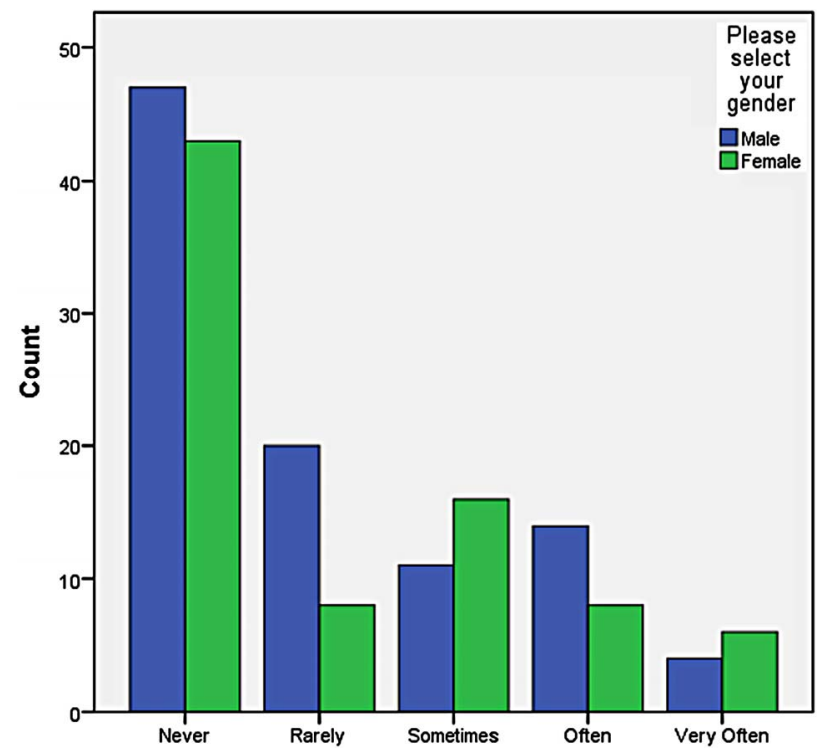

Figure 2.

Crosstabulation-Facebook utilization for instructional purposes by gender.

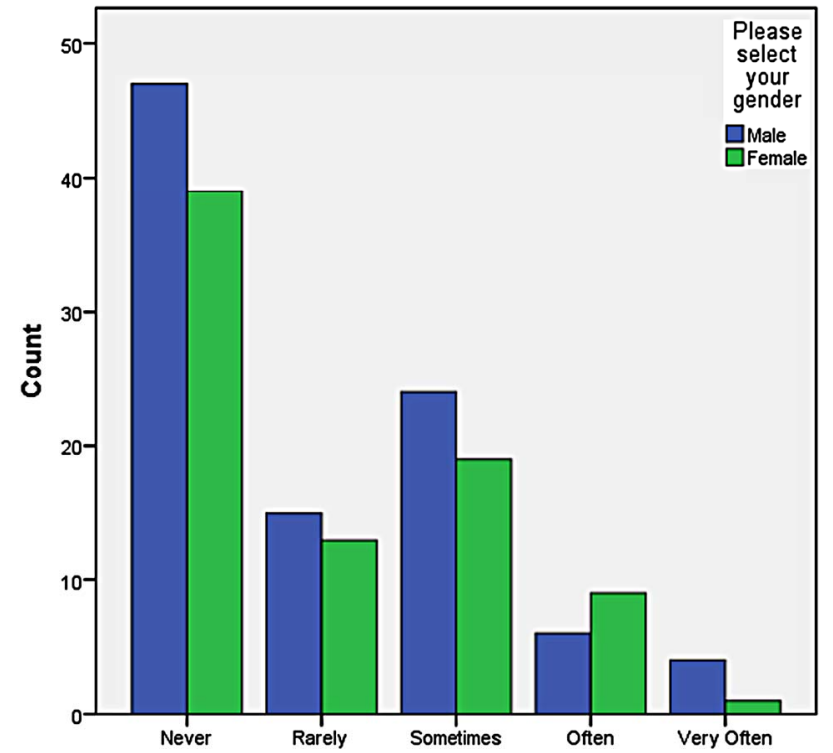

Figure 3.

Crosstabulation-Podcast utilization for instructional purposes by gender.

Reviewing the results with highest count indicates that male faculty members had a higher count on never utilizing Second Life, rarely utilizing Second Life, sometimes utilizing Second Life, and often utilizing Second Life for instructional purposes. Neither male nor female faculty members measured on the chart as very often utilizing Second Life for instructional purposes. Figure 5 shows the impact of gender on the level of Skype utilization at their respective university.

Reviewing the results with highest count indicates that male faculty members had a higher count on never utilizing Skype, rarely utilizing Skype, often utilizing Skype, and very often utilizing Skype for instructional purposes. Female faculty members had a higher count on sometimes utilizing Skype for in- 


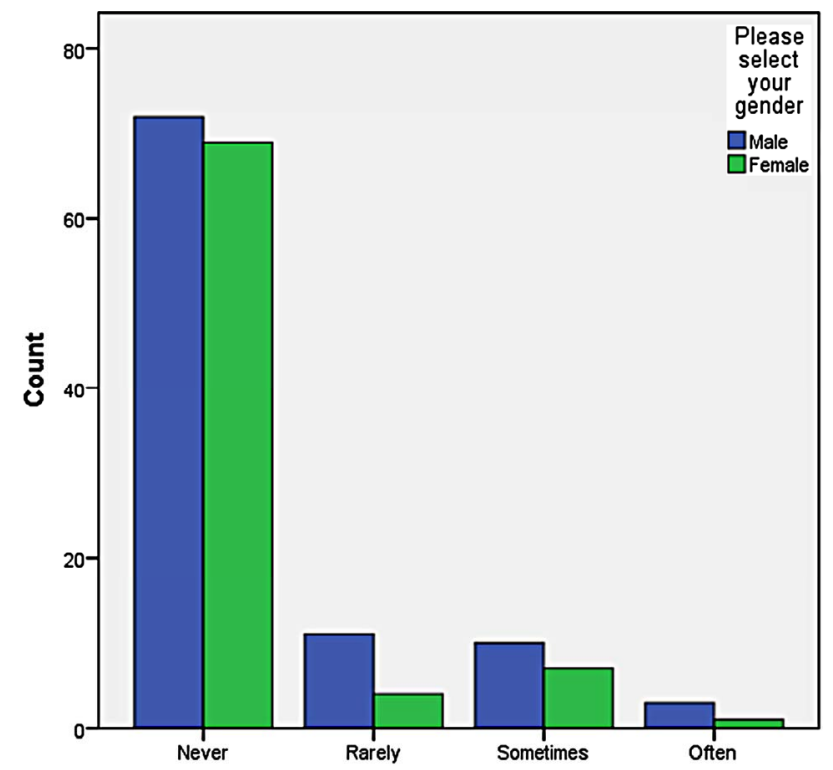

Figure 4.

Crosstabulation-Second Life utilization for instructional purposes by gender.

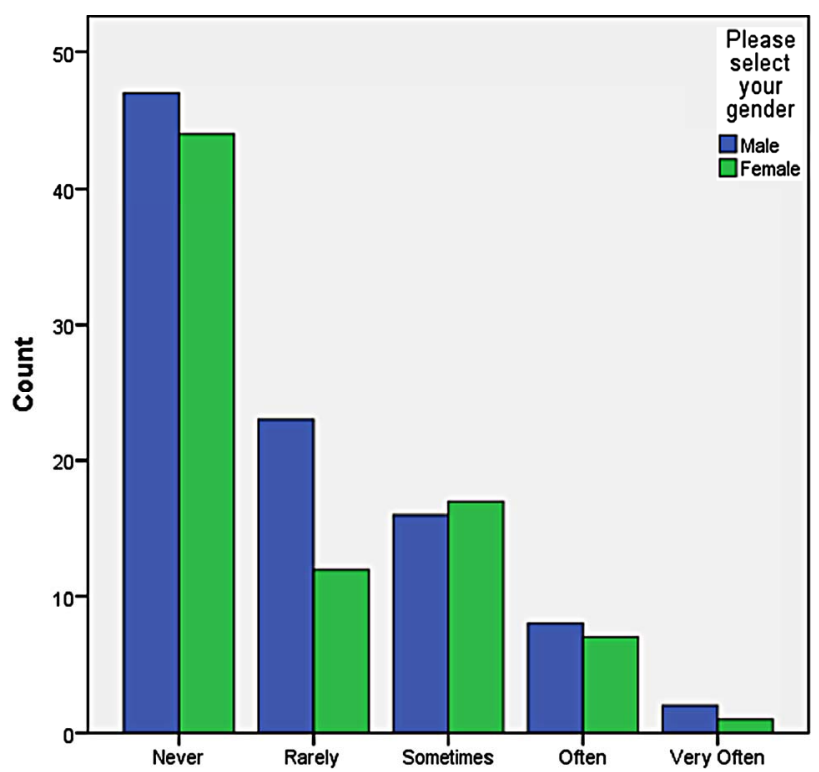

Figure 5.

Crosstabulation - Skype utilization for instructional purposes by gender.

structional purposes. Figure 6 shows the impact of gender on the level of Twitter utilization at their respective university.

Reviewing the results with highest count indicates that male faculty members had a higher count on never utilizing Twitter, sometimes utilizing Twitter, and often utilizing Twitter for instructional purposes. Female faculty members had a higher count on rarely utilizing Twitter, and very often utilizing Twitter for instructional purposes. Figure 7 shows the impact of gender on the level of Wiki utilization at their respective university.

Reviewing the results with highest count indicates that male faculty members had a higher count on never utilizing Wikis, rarely utilizing Wikis, sometimes utilizing Wikis, and often utilizing Wikis for instructional purposes. Female faculty mem- bers were tied with male faculty members on the count for very often utilizing Wikis for instructional purposes. Figure 8 shows the impact of gender on the level of YouTube utilization at their respective university.

Reviewing the results with highest count indicates that male faculty members had a higher count on never utilizing YouTube, rarely utilizing YouTube, and often utilizing YouTube for instructional purposes. Female faculty members had a higher count on sometimes utilizing YouTube and very often utilizing YouTube for instructional purposes.

Crosstablulation analyses were conducted to understand the impact of age on the level of Web 2.0 technology utilization at the faculty members' perspective university. Figure 9 shows

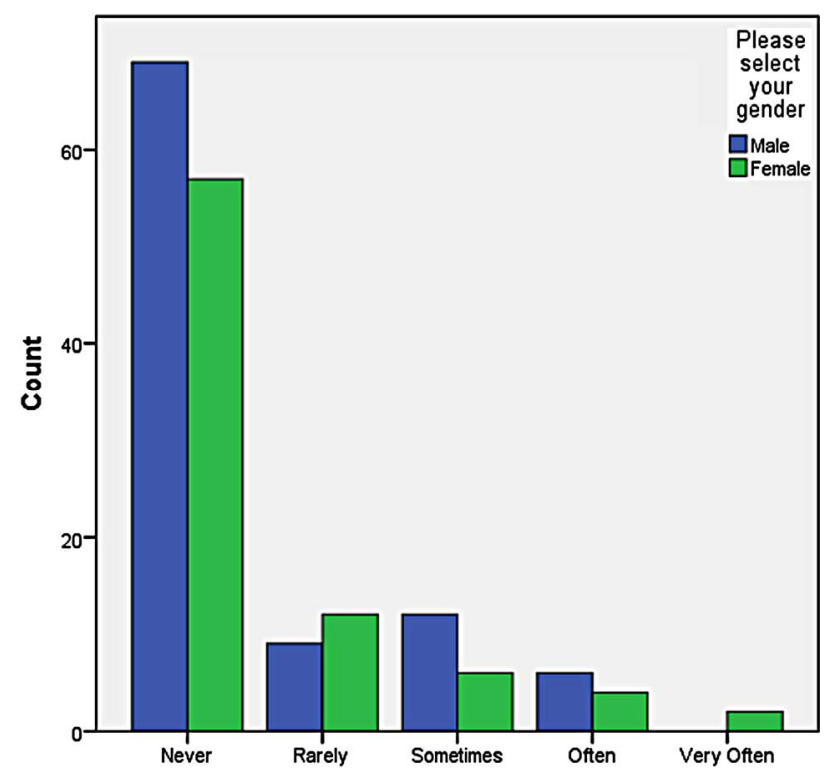

Figure 6.

Crosstabulation-Twitter utilization for instructional purposes by gender.

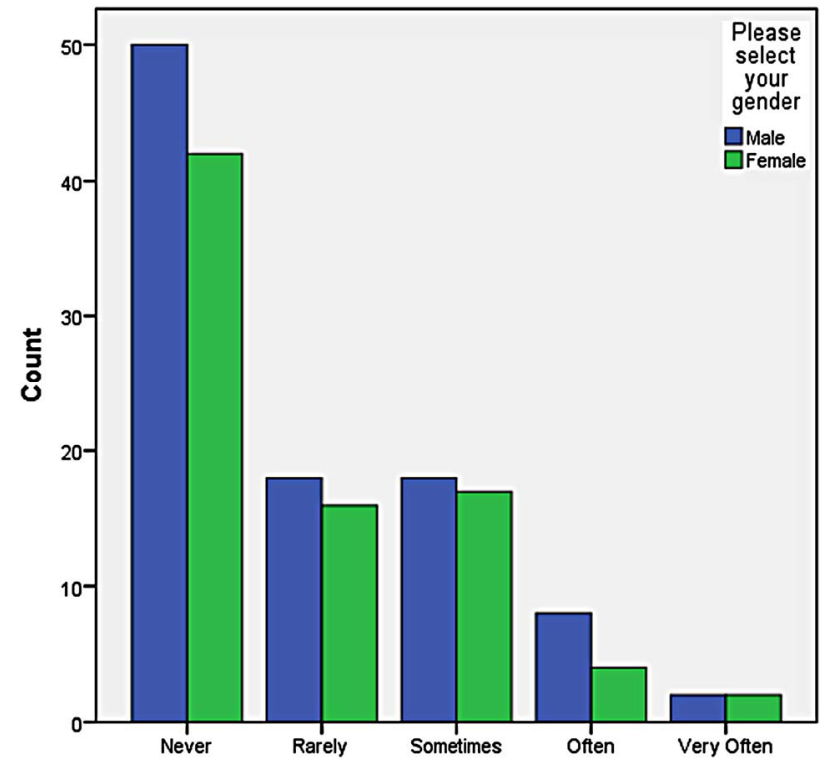

Figure 7.

Crosstabulation-Wiki utilization for instructional purposes by gender. 


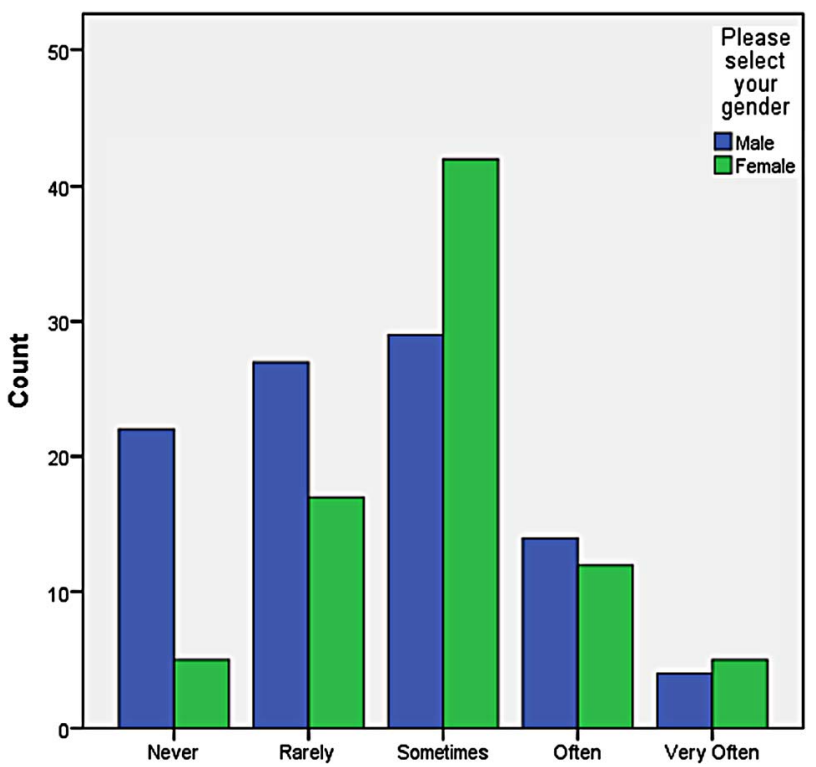

Figure 8.

Crosstabulation-YouTube utilization for instructional purposes by gender.

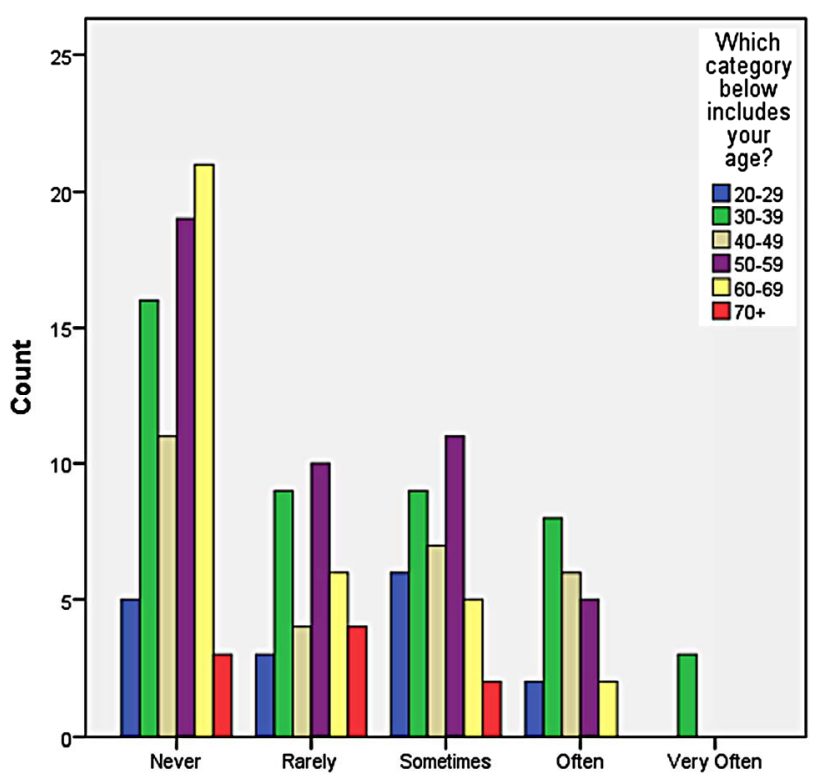

Figure 9.

Crosstabulation-Blog utilization for instructional purposes by age.

the impact of age on the level of Blog utilization at faculty members' respective university.

Reviewing the results with highest count indicates overall, participants in the age range of 60 - 69 have never utilized Blogs; participants in the age range of 50 - 59 have rarely utilized Blogs and sometimes utilized Blogs; participants in the age range of 30 - 39 often utilize Blogs and very often utilized Blogs for instructional purposes. Figure 10 shows the impact of age on the level of Facebook utilization at the faculty members' respective university.

Reviewing the results with highest count indicates overall, participants in the age range of 60 - 69 have never utilized Facebook; participants in the age range of 50 - 59 have rarely utilized Facebook; participants in the age range of $30-39$ sometimes utilized Facebook and very often utilized Facebook for instructional purposes. Participants in the age range of 30 39 tied with participants in the age range of $40-49$ who often utilize Facebook for instructional purposes. Figure 11 shows the impact of age on the level of Podcast utilization at the faculty members' respective university.

Reviewing the results with highest count indicates overall, participants in the age range of 50 - 59 have never utilized Podcasts and have very often utilized Podcast; participants in the age range of 30 - 39 sometimes utilized Podcasts; participants in the age range of $30-39$ and 40 - 49 tied with the count of those who rarely utilized Podcast and often utilized Podcast for

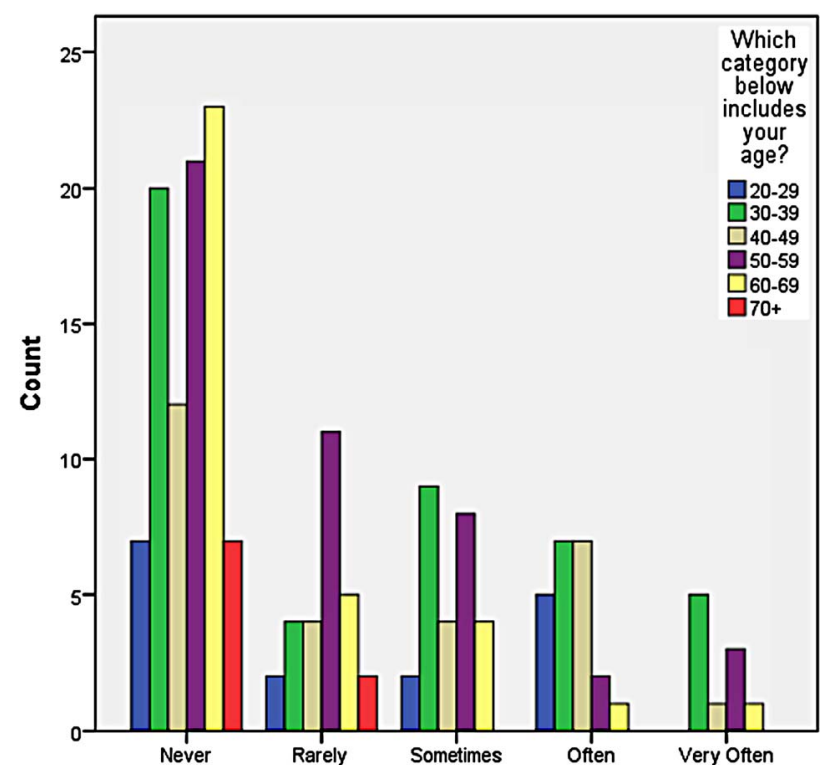

Figure 10.

Crosstabulation-Facebook utilization for instructional purposes by age.

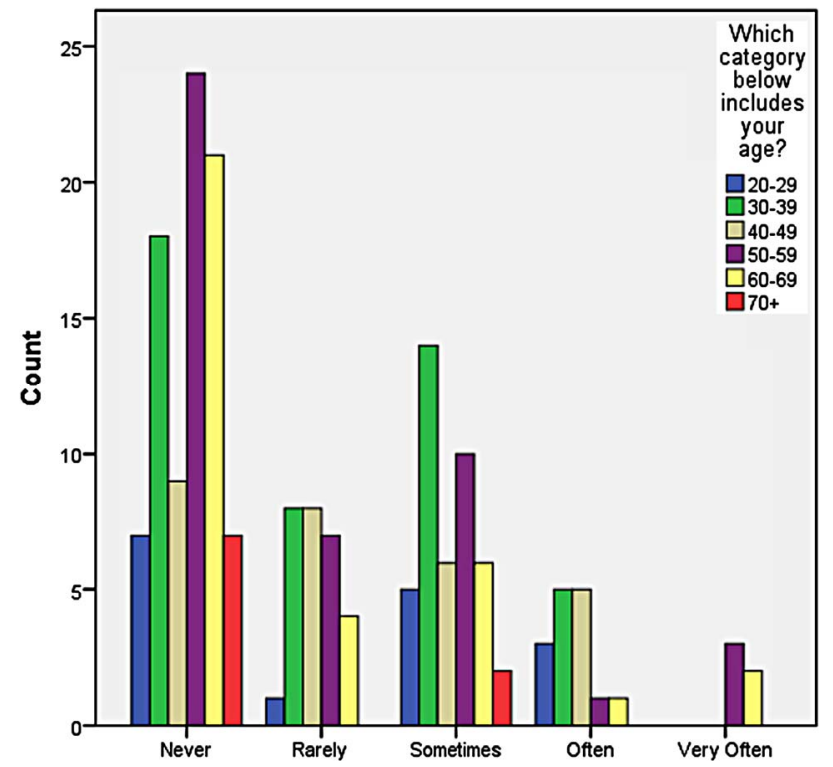

Figure 11.

Crosstabulation-Podcast utilization for instructional purposes by age. 
instructional purposes. Figure 12 shows the impact of age on the level of Second Life utilization at the faculty members' respective universities.

Reviewing the results with highest count indicates overall, participants in the age range of 50 - 59 have never utilized Second Life, and have rarely utilized Second Life; participants in the age range of 30 - 39 sometimes utilized Second Life; and participants in the age range of 20 - 29 have often utilized Second Life for instructional purposes. Figure 13 shows the impact of age on the level of Skype utilization at the faculty members' respective university.

Reviewing the results with highest count indicates overall, participants in the age range of 50 - 59 have never utilized

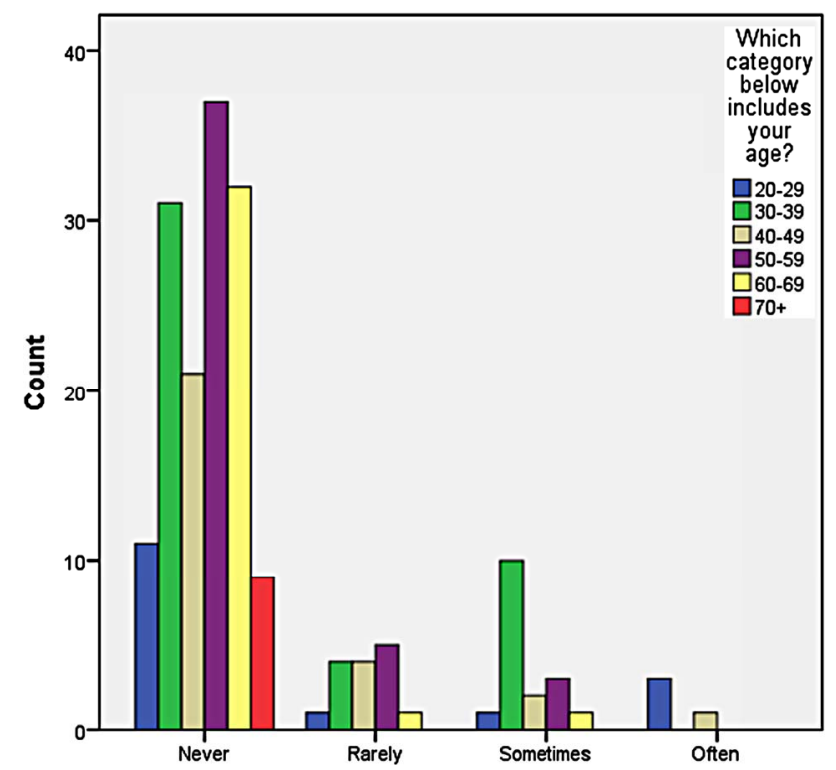

Figure 12.

Crosstabulation-Second Life utilization for instructional purposes by age.

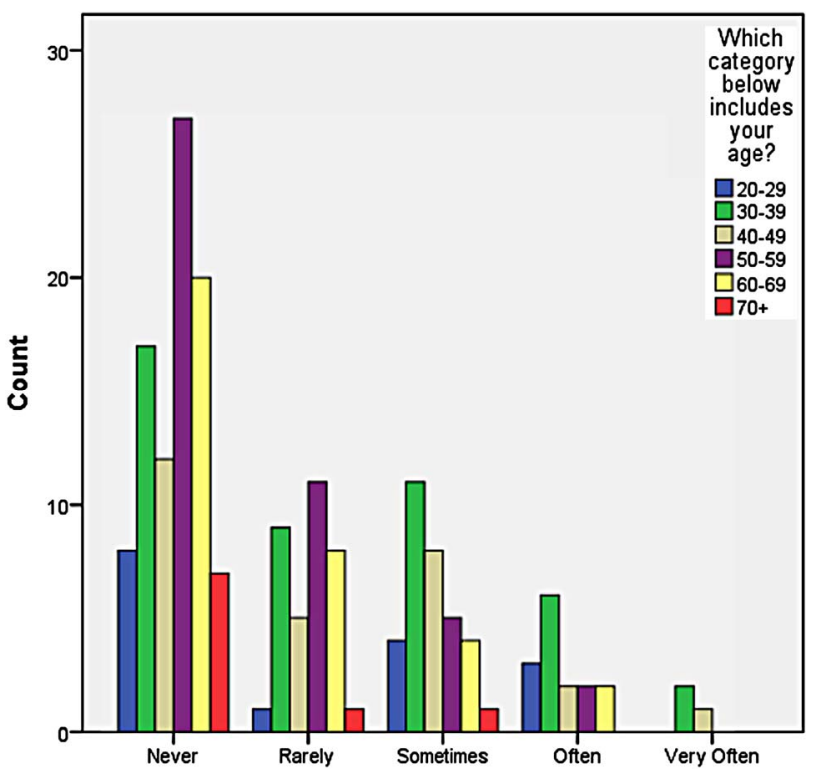

Figure 13.

Crosstabulation-Skype utilization for instructional purposes by age.
Skype, and have rarely utilized Second Life; participants in the age range of 30 - 39 sometimes utilized Skype, often utilized Skype and very often utilized Skype for instructional purposes. Figure 14 shows the impact of age on the level of Twitter utilization at the faculty members' respective university.

Reviewing the results with highest count indicates overall, participants in the age range of 50 - 59 have never utilized Twitter; participants in the age range of 30 - 39 rarely utilized Twitter, sometimes utilized Twitter, and often utilized Twitter; participants in the age range of $40-49$ and 50 - 59 tied with the count of those who very often utilized Twitter for instructional purposes. Figure 15 shows the impact of age on the level of Wiki utilization at the faculty members' respective university.

Reviewing the results with highest count indicates overall,

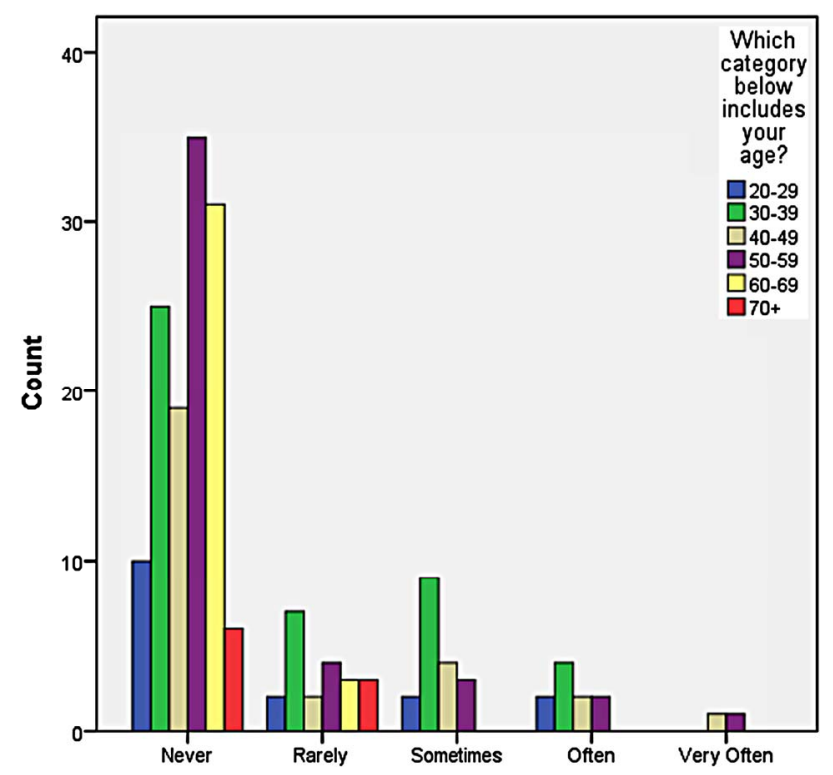

Figure 14.

Crosstabulation-Twitter utilization for instructional purposes by age.

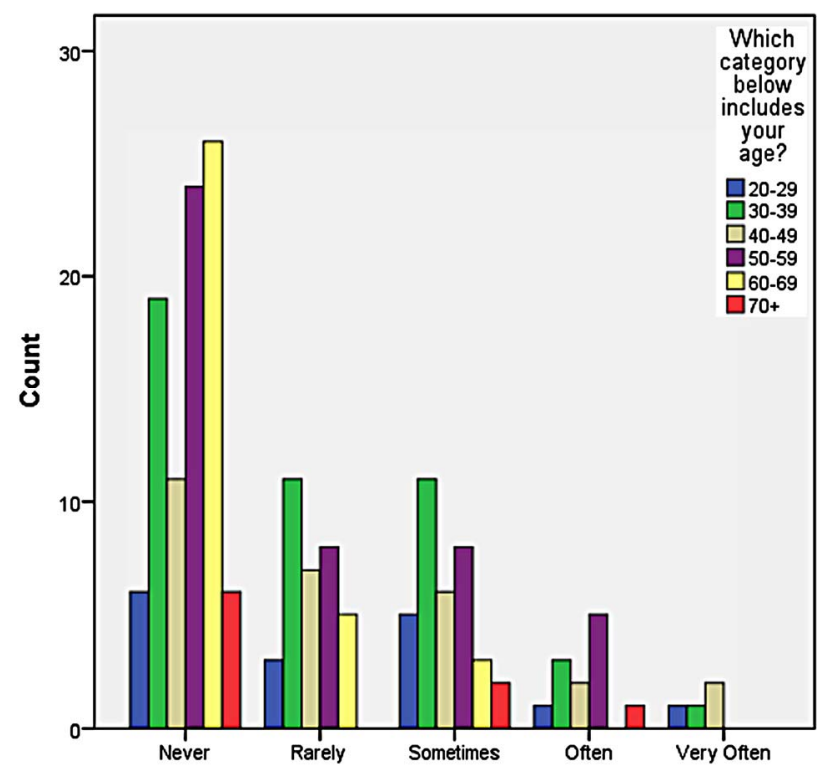

Figure 15.

Crosstabulation-Wiki utilization for instructional purposes by age. 
participants in the age range of 60 - 69 have never utilized Wikis; participants in the age range of 30 - 39 rarely utilized Wikis and sometimes utilized Wikis; participants in the age range of 50 - 59 often utilized Wikis; and participants in the age range of 40 - 49 very often utilized Wikis for instructional purposes. Figure 16 shows the impact of age on the level of YouTube utilization at the faculty members' respective university.

Reviewing the results with highest count indicates overall, participants in the age range of 50 - 59 have never utilized YouTube, and have rarely utilized YouTube; participants in the age range of 30 - 39 sometimes utilized YouTube, often utilized YouTube and very often utilized YouTube for instructional purposes.

Crosstablulation analyses were conducted to understand the impact of employment status on the level of Web 2.0 technology use at the faculty members' university. Figure 17 shows the impact of employment status on the level of Blog utilization at faculty members' respective university.

Reviewing the results with highest count indicates overall, participants whose employment status was adjunct have never utilized Blogs, have rarely utilized Blogs, have sometimes utilized Blogs, and have very often utilized Blogs; participants whose employment status was professor often utilized Blogs for instructional purposes. Figure 18 shows the impact of employment status on the level of Facebook utilization at faculty members' respective university.

Reviewing the results with highest count indicates overall, participants whose employment status was adjunct have never utilized Facebook, have rarely utilized Facebook, have sometimes utilized Facebook, have often utilized Facebook, and have very often utilized Facebook for instructional purposes. Figure 19 shows the impact of employment status on the level of Podcast utilization at faculty members' respective university.

Reviewing the results with highest count indicates overall, participants whose employment status was adjunct have never utilized Podcasts, have rarely utilized Podcasts, and have sometimes utilized Podcast for instructional purposes. Participants

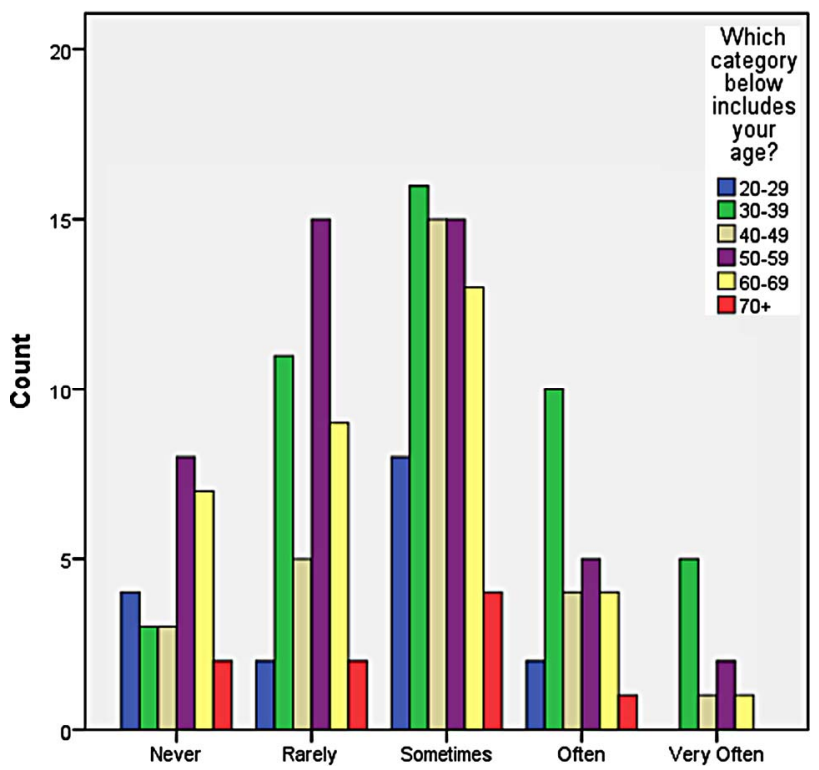

Figure 16.

Crosstabulation-YouTube utilization for instructional purposes by age.

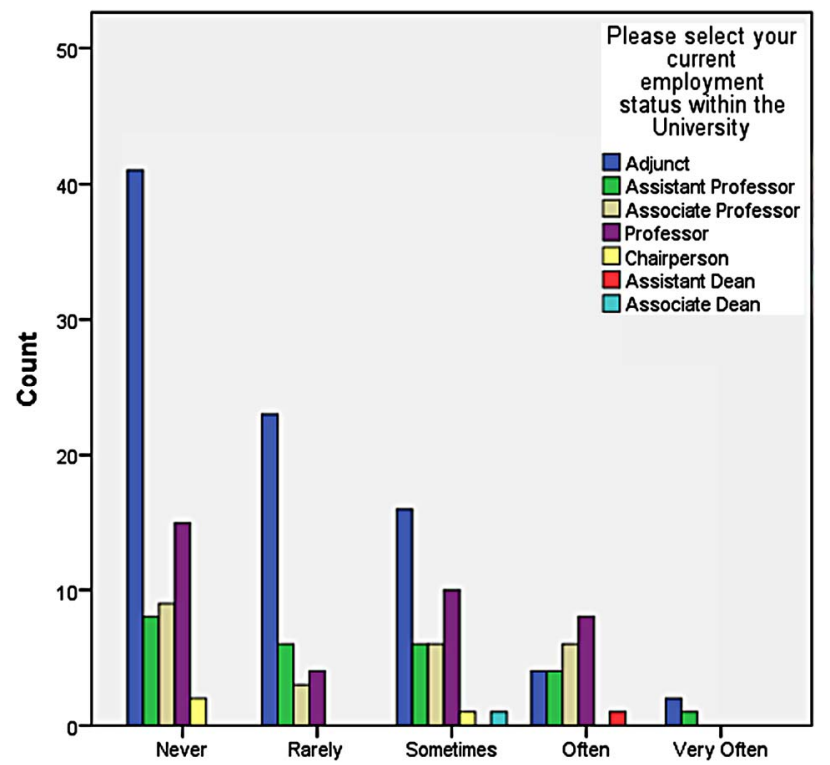

Figure 17.

Crosstabulation-Blog utilization for instructional purposes by employment status.

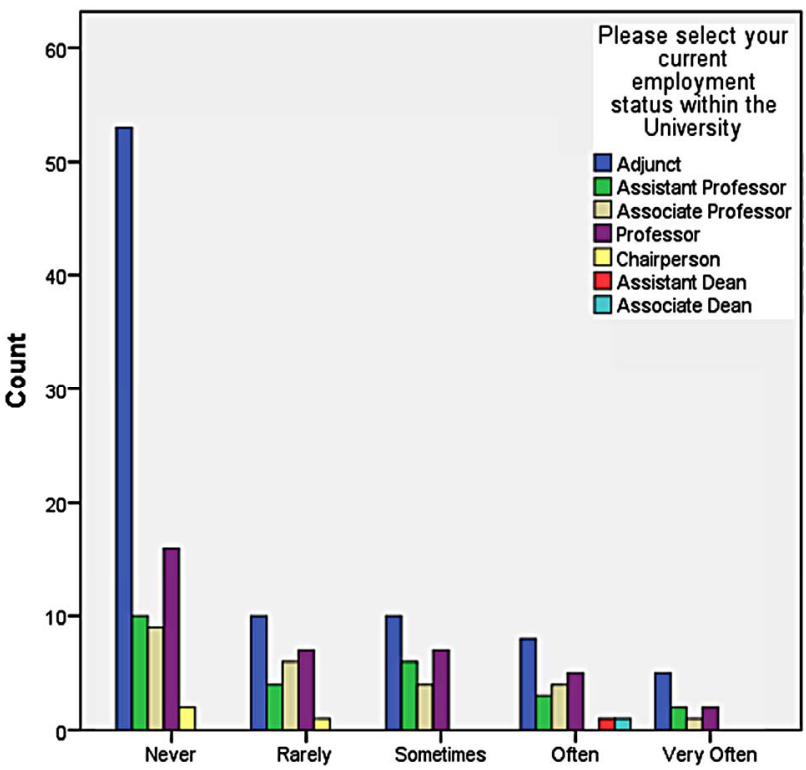

Figure 18.

Crosstabulation-Facebook utilization for instructional purposes by employment status.

whose employment status was assistant professor, associate professor and professor tied in the count for those who often utilized Podcasts; and participants whose employment status was assistant professor and professor tied in the count for those who very often utilized Podcasts for instructional purposes. Figure 20 shows the impact of employment status on the level of Second Life utilization at faculty members' respective university.

Reviewing the results with highest count indicates overall, participants whose employment status was adjunct have never utilized Second Life, and have sometimes utilized Second Life for instructional purposes. Participants whose employment status 


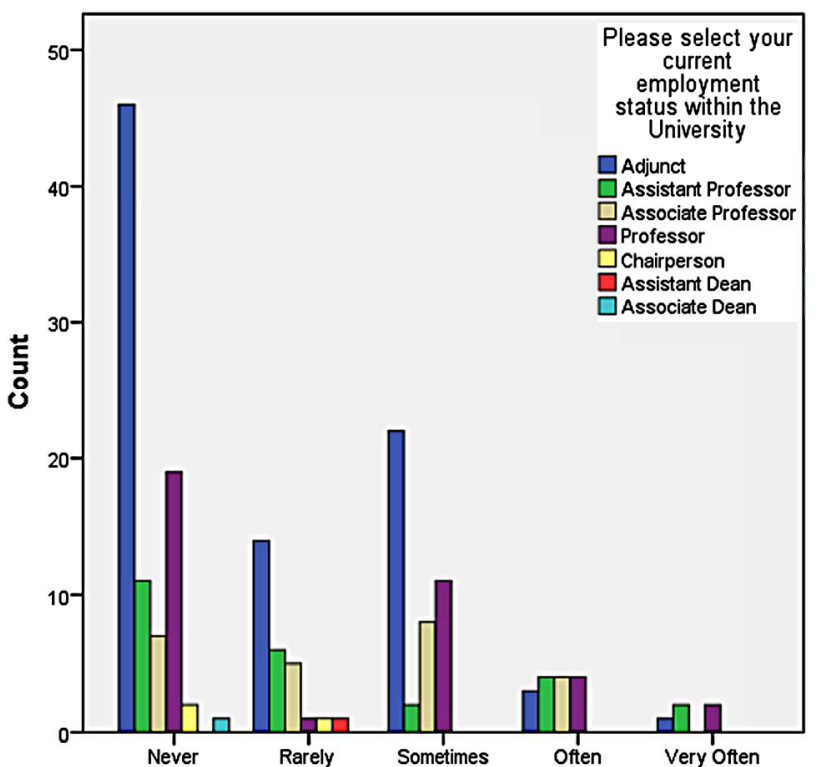

Figure 19.

Crosstabulation-Podcast utilization for instructional purposes by employment status.

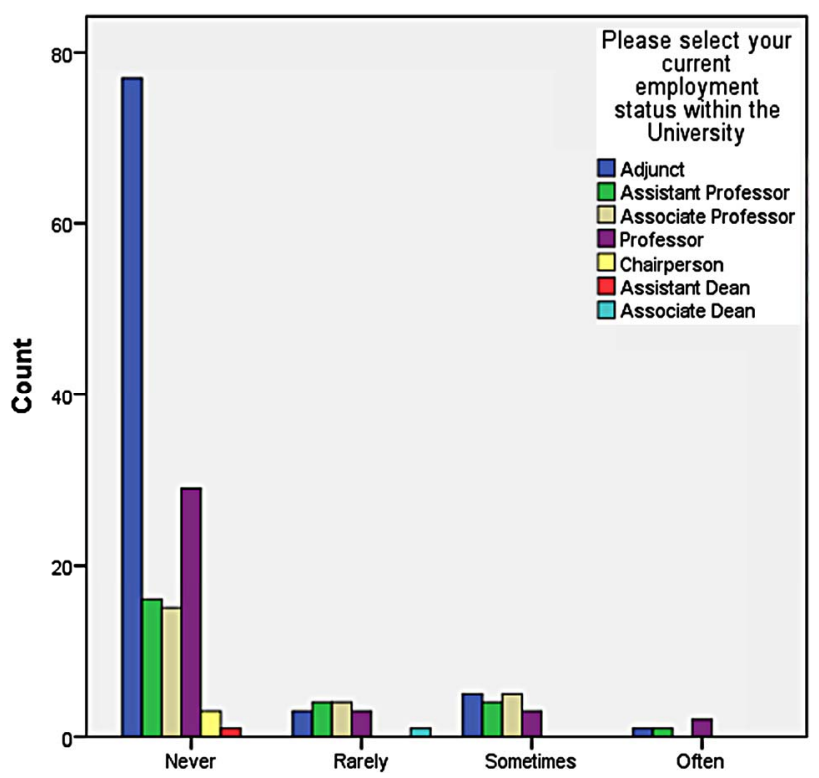

Figure 20.

Crosstabulation-Second Life utilization for instructional purposes by employment status.

was professor often utilized Second Life; participants whose employment status was assistant professor and associate professor tied in the count for those who rarely utilized Second Life; and participants whose employment status was adjunct and associate professor tied in the count for those who sometimes utilized Second Life for instructional purposes. Figure 21 shows the impact of employment status on the level of Skype utilization at faculty members' respective university.

Reviewing the results with highest count indicates overall, participants whose employment status was adjunct have never utilized Skype, have rarely utilized Skype, have sometimes utilized Skype, and have very often utilized Skype for instructional purposes. Participants whose employment status was professor often utilized Skype for instructional purposes. Figure 22 shows the impact of employment status on the level of Twitter utilization at faculty members' respective university.

Reviewing the results with highest count indicates overall, participants whose employment status was adjunct have never utilized Twitter, and have rarely utilized Twitter for instructional purposes. Participants whose employment status was professor have often utilized Twitter. Participants whose employment status was adjunct and associate professor tied for the count of those who sometimes utilized Twitter and very often utilized Twitter for instructional purposes. Figure 23 shows the

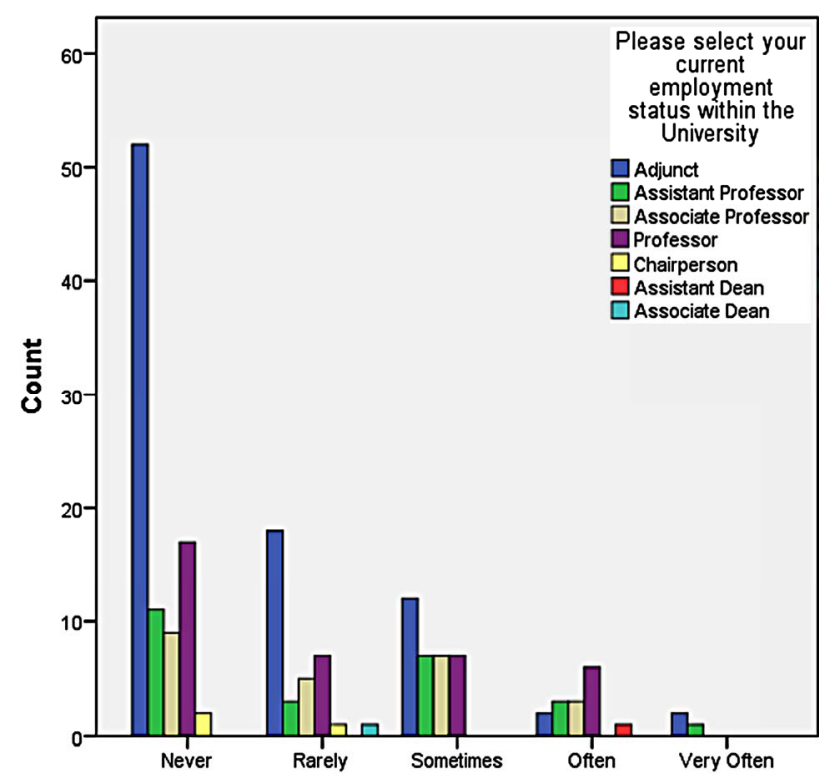

Figure 21.

Crosstabulation-Skype utilization for instructional purposes by employment status.

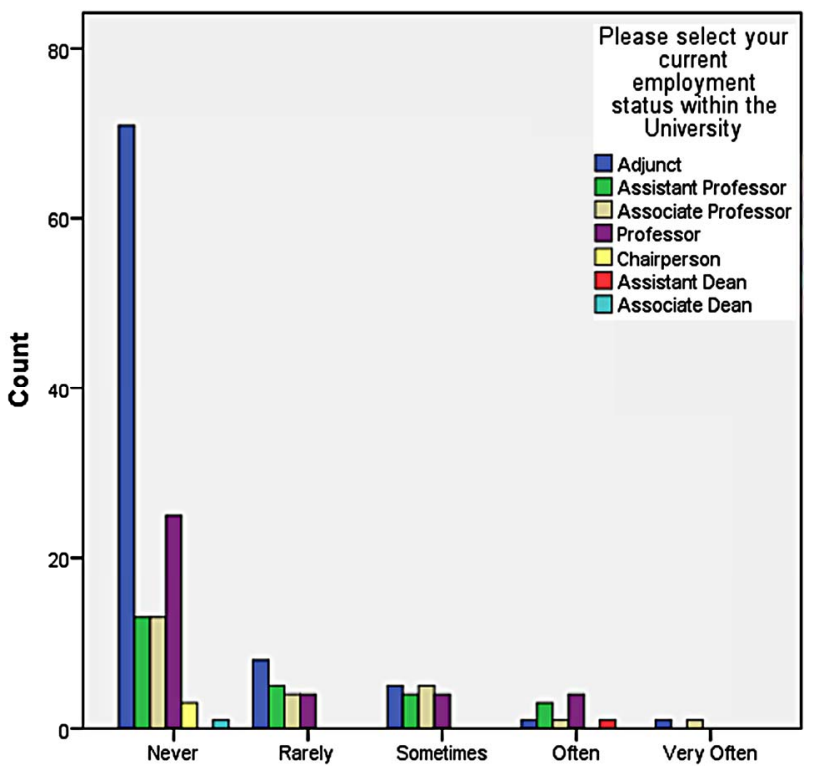

Figure 22.

Crosstabulation-Twitter utilization for instructional purposes by employment status. 
impact of employment status on the level of Wiki utilization at faculty members' respective university.

Reviewing the results with highest count indicates overall, participants whose employment status was adjunct have never utilized Wikis, have rarely utilized Wikis, and have often utilized Wikis for instructional purposes. Participants whose employment status was adjunct and tied for the count of those who sometimes utilized Wikis; and participants whose employment status was adjunct, assistant professor, associate professor, and professor tied for the count of those who very often utilized Wikis for instructional purposes. Figure 24 shows the impact of employment status on the level of YouTube utilization at faculty members' respective university.

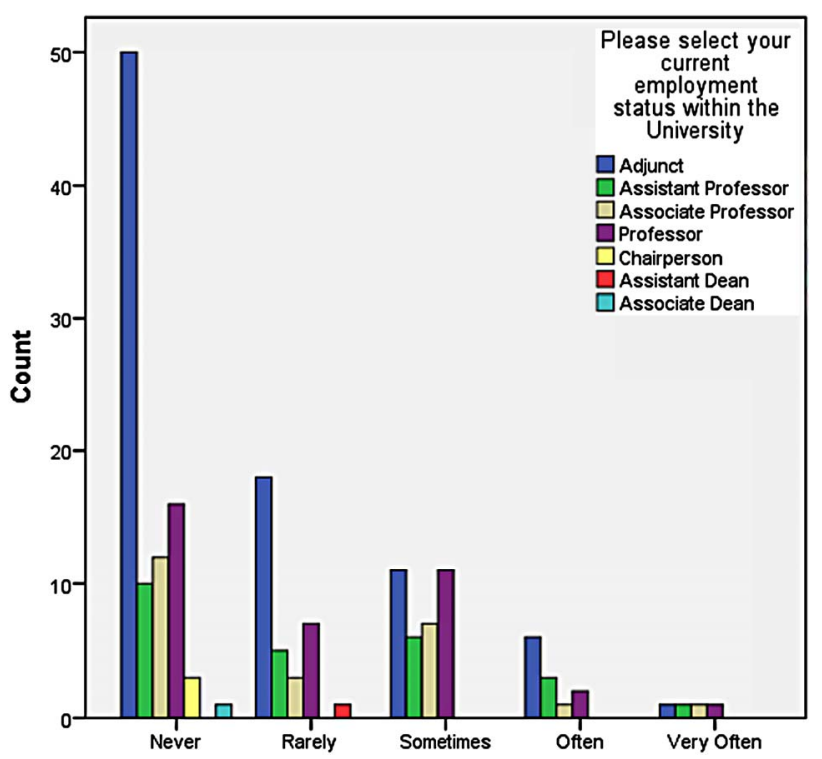

Figure 23.

Crosstabulation-Wiki utilization for instructional purposes by employment status.

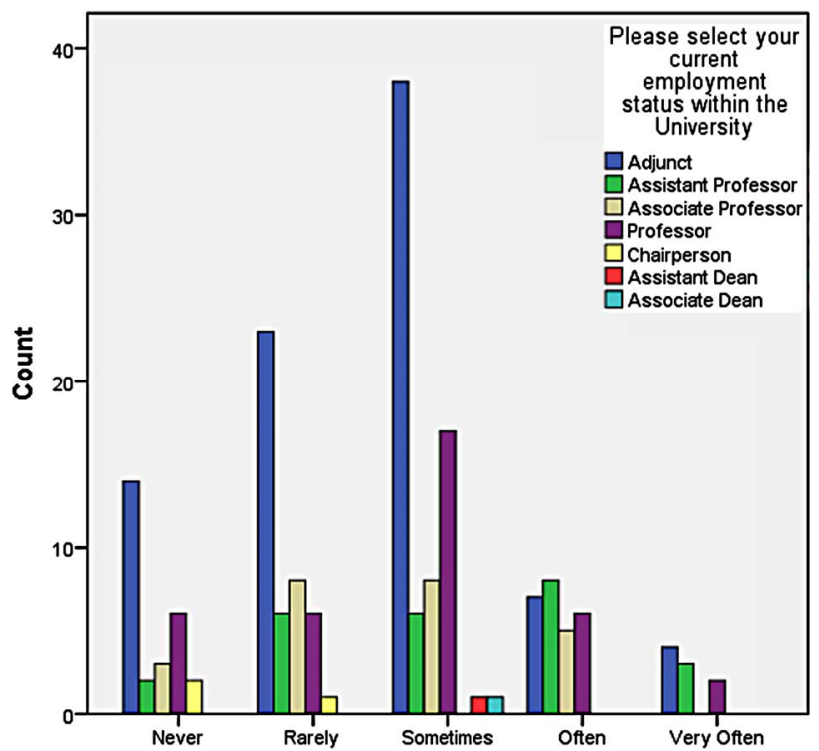

Figure 24.

Crosstabulation-YouTube utilization for instructional purposes by employment status.
Reviewing the results with highest count indicates overall, participants whose employment status was adjunct have never utilized YouTube, have rarely utilized YouTube, have sometimes utilized YouTube, and have very often utilized YouTube for instructional purposes. Participants whose employment status was assistant professor often utilized YouTube for instructional purposes.

Section 3 of the survey included 19 questions that asked the faculty members, by using a scale of strongly disagree to strongly agree, to identify which statements most closely matches their agreement with each statement. Survey Question 22 asked the participants if using Web 2.0 technologies improve the quality of teaching. Table $\mathbf{2 4}$ shows the results.

The majority of the faculty members ( 82 or $46.3 \%$ ) felt neutral about the utilization of Web 2.0 technologies improving the quality of teaching, while 65 or $36.7 \%$ of the faculty members agreed that using Web 2.0 technologies improves the quality of teaching. Of the 177 participants, 12 or $6.8 \%$ of the faculty members strongly agreed that using Web 2.0 technologies improves the quality of teaching. Survey Question 23 asked the participants if using Web 2.0 technologies enhances student's experience. The results of this question are in Table 25.

The majority of the faculty members ( 81 or $45.8 \%$ ) agreed that using Web 2.0 technologies enhances student's experiences, while 65 or $36.7 \%$ of the faculty members remained neutral. Of the 177 participants, 15 or $8.5 \%$ of the faculty members strongly agreed that using Web 2.0 technologies enhances student's experience, and 11 or $6.2 \%$ disagreed with the statement. Survey Question 24 asked the participants if learning to use Web 2.0 technologies was easy for them. The results of this question can be found in Table 26.

Table 24.

Frequency table - using Web 2.0 technologies improves the quality of teaching.

\begin{tabular}{|c|c|c|c|c|c|}
\hline & & Frequency & Percent & $\begin{array}{c}\text { Valid } \\
\text { Percent }\end{array}$ & $\begin{array}{l}\text { Cumulative } \\
\text { Percent }\end{array}$ \\
\hline \multirow{5}{*}{ Valid } & $\begin{array}{l}\text { Strongly } \\
\text { Disagree }\end{array}$ & 7 & .6 & 4.0 & \multirow[t]{5}{*}{ Valid } \\
\hline & Disagree & 11 & .9 & 6.2 & \\
\hline & Neutral & 82 & 6.8 & 46.3 & \\
\hline & Agree & 65 & 5.4 & 36.7 & \\
\hline & $\begin{array}{l}\text { Strongly } \\
\text { Agree }\end{array}$ & 12 & 1.0 & 6.8 & \\
\hline \multirow{3}{*}{ Missing } & Total & 177 & 14.7 & 100.0 & \multirow{3}{*}{ Missing } \\
\hline & System & 1030 & 85.3 & & \\
\hline & tal & 1207 & 100.0 & & \\
\hline
\end{tabular}

Table 25.

Frequency table-using Web 2.0 technologies enhances student's experiences in the classroom.

\begin{tabular}{|c|c|c|c|c|c|}
\hline & & Frequency & Percent & $\begin{array}{c}\text { Valid } \\
\text { Percent }\end{array}$ & $\begin{array}{c}\text { Cumulative } \\
\text { Percent }\end{array}$ \\
\hline \multirow{5}{*}{ Valid } & $\begin{array}{l}\text { Strongly } \\
\text { Disagree }\end{array}$ & 5 & .4 & 2.8 & 2.8 \\
\hline & Disagree & 11 & .9 & 6.2 & 9.0 \\
\hline & Neutral & 65 & 5.4 & 36.7 & 45.8 \\
\hline & Agree & 81 & 6.7 & 45.8 & 91.5 \\
\hline & $\begin{array}{l}\text { Strongly } \\
\text { Agree }\end{array}$ & 15 & 1.2 & 8.5 & 100.0 \\
\hline \multirow{3}{*}{ Missing } & Total & 177 & 14.7 & 100.0 & \\
\hline & System & 1030 & 85.3 & & \\
\hline & Total & 1207 & 100.0 & & \\
\hline
\end{tabular}


Table 26.

Frequency table-learning to use Web 2.0 technologies is easy for me.

\begin{tabular}{|c|c|c|c|c|c|}
\hline & & Frequency & Percent & $\begin{array}{l}\text { Valid } \\
\text { Percent }\end{array}$ & $\begin{array}{c}\text { Cumulative } \\
\text { Percent }\end{array}$ \\
\hline \multirow{5}{*}{ Valid } & $\begin{array}{l}\text { Strongly } \\
\text { Disagree }\end{array}$ & 5 & .4 & 2.8 & 2.8 \\
\hline & Disagree & 17 & 1.4 & 9.6 & 12.4 \\
\hline & Neutral & 70 & 5.8 & 39.5 & 52.0 \\
\hline & Agree & 67 & 5.6 & 37.9 & 89.8 \\
\hline & $\begin{array}{l}\text { Strongly } \\
\text { Agree }\end{array}$ & 18 & 1.5 & 10.2 & 100.0 \\
\hline \multirow{3}{*}{ Missing } & Total & 177 & 14.7 & 100.0 & \\
\hline & System & 1030 & 85.3 & & \\
\hline & Total & 1207 & 100.0 & & \\
\hline
\end{tabular}

The majority of the faculty members ( 70 or $39.5 \%$ ) remained neutral while 67 or $37.9 \%$ of the faculty agreed that learning to use Web 2.0 technologies is easy for them. Of the 177 participants, 18 or $10.2 \%$ strongly agreed that learning to use Web 2.0 technologies is easy for them, 17 or $9.6 \%$ disagreed and 5 or $2.8 \%$ strongly disagreed with the statement. Survey Question 25 asked the participants if learning to use Web 2.0 technologies is beneficial to them as a faculty member in higher education. The results of this question can be found in Table 27.

The majority of the faculty members ( 83 or $46.9 \%$ ) agreed that learning to use Web 2.0 technologies is beneficial to them as a faculty member in higher education and 55 or $31.1 \%$ remained neutral. Of the 177 participants, 26 or $14.7 \%$ strongly agreed that learning to use Web 2.0 technologies is beneficial to them as a faculty member in higher education and the minority either disagreed ( 8 or $4.5 \%$ ) or strongly disagreed (5 or $2.8 \%$ ) that learning to use Web 2.0 technologies is beneficial to them as a faculty member in higher education. Survey Question 26 asked the participants if their students expected them to use Web 2.0 technology for instruction. The results of this question can be found in Table 28.

The majority of the faculty members ( 77 or $43.5 \%$ ) remained neutral and 46 or $26 \%$ of the faculty agreed that their students expected them to use Web 2.0 technology for instruction. Of the 177 participants, 30 or $16.9 \%$ disagreed and 12 or $6.8 \%$ both strongly disagreed and strongly agreed that their students expected them to us Web 2.0 technology for instruction. Survey Question 27 asked the participants to rate their level of agreement to the following statement: There are no differences in what I taught utilizing Web 2.0 technologies versus the traditional classroom method. The results of this question can be found in Table 29.

The majority of the faculty members ( 65 or $36.7 \%$ ) disagreed while 57 or $32.2 \%$ of the faculty members remained neutral regarding the statement. While 28 or $15.8 \%$ of the faculty members agreed and 10 or $5.6 \%$ of the faculty members strongly agreed that there were no differences in what they taught utilizing Web 2.0 technologies versus the traditional classroom method, 17 or $9.6 \%$ of the faculty strongly disagreed with the statement. Survey Question 28 asked the participants if infusing Web 2.0 technologies within their course content was a requirement for them. The results of this question can be found in Table 30.

The majority of the faculty members ( 54 or $30.5 \%$ ) disagreed while 51 or $28.8 \%$ of the faculty members remained neutral regarding the statement. While 37 or $20.9 \%$ of the faculty
Table 27.

Frequency table-learning to use Web 2.0 technologies is beneficial to me as a faculty member in higher education.

\begin{tabular}{cccccc}
\hline \multirow{4}{*}{ Valid } & Frequency & Percent & $\begin{array}{c}\text { Valid } \\
\text { Percent }\end{array}$ & $\begin{array}{c}\text { Cumulative } \\
\text { Percent }\end{array}$ \\
\hline \multirow{5}{*}{ Strongly Disagree } & 5 & .4 & 2.8 & 2.8 \\
& Disagree & 8 & .7 & 4.5 & 7.3 \\
& Neutral & 55 & 4.6 & 31.1 & 38.4 \\
& Agree & 83 & 6.9 & 46.9 & 85.3 \\
\multirow{4}{*}{ Missing } & Strongly Agree & 26 & 2.2 & 14.7 & 100.0 \\
& Total & 177 & 14.7 & 100.0 & \\
& System & 1030 & 85.3 & & \\
& Total & 1207 & 100.0 & & \\
\hline
\end{tabular}

Table 28.

Frequency table - my students expect me to use Web 2.0 technologies for instruction.

\begin{tabular}{|c|c|c|c|c|c|}
\hline & & Frequency & Percent & $\begin{array}{l}\text { Valid } \\
\text { Percent }\end{array}$ & $\begin{array}{c}\text { Cumulative } \\
\text { Percent }\end{array}$ \\
\hline \multirow{5}{*}{ Valid } & $\begin{array}{l}\text { Strongly } \\
\text { Disagree }\end{array}$ & 12 & 1.0 & 6.8 & 6.8 \\
\hline & Disagree & 30 & 2.5 & 16.9 & 23.7 \\
\hline & Neutral & 77 & 6.4 & 43.5 & 67.2 \\
\hline & Agree & 46 & 3.8 & 26.0 & 93.2 \\
\hline & $\begin{array}{c}\text { Strongly } \\
\text { Agree }\end{array}$ & 12 & 1.0 & 6.8 & 100.0 \\
\hline \multirow{3}{*}{ Missing } & Total & 177 & 14.7 & 100.0 & \\
\hline & System & 1030 & 85.3 & & \\
\hline & Total & 1207 & 100.0 & & \\
\hline
\end{tabular}

Table 29.

Frequency table- there are no differences in what I taught utilizing Web 2.0 technologies versus the traditional classroom method.

\begin{tabular}{|c|c|c|c|c|c|}
\hline & & Frequency & Percent & $\begin{array}{c}\text { Valid } \\
\text { Percent }\end{array}$ & $\begin{array}{c}\text { Cumulative } \\
\text { Percent }\end{array}$ \\
\hline \multirow{5}{*}{ Valid } & $\begin{array}{l}\text { Strongly } \\
\text { Disagree }\end{array}$ & 17 & 1.4 & 9.6 & 9.6 \\
\hline & Disagree & 65 & 5.4 & 36.7 & 46.3 \\
\hline & Neutral & 57 & 4.7 & 32.2 & 78.5 \\
\hline & Agree & 28 & 2.3 & 15.8 & 94.4 \\
\hline & $\begin{array}{l}\text { Strongly } \\
\text { Agree }\end{array}$ & 10 & .8 & 5.6 & 100.0 \\
\hline \multirow{3}{*}{ Missing } & Total & 177 & 14.7 & 100.0 & \\
\hline & System & 1030 & 85.3 & & \\
\hline & Total & 1207 & 100.0 & & \\
\hline
\end{tabular}

Table 30.

Frequency table-infusing Web 2.0 technologies within my course content is a requirement for me.

\begin{tabular}{|c|c|c|c|c|c|}
\hline & & Frequency & Percent & $\begin{array}{c}\text { Valid } \\
\text { Percent }\end{array}$ & $\begin{array}{c}\text { Cumulative } \\
\text { Percent }\end{array}$ \\
\hline \multirow{5}{*}{ Valid } & $\begin{array}{l}\text { Strongly } \\
\text { Disagree }\end{array}$ & 28 & 2.3 & 15.8 & 15.8 \\
\hline & Disagree & 54 & 4.5 & 30.5 & 46.3 \\
\hline & Neutral & 51 & 4.2 & 28.8 & 75.1 \\
\hline & Agree & 37 & 3.1 & 20.9 & 96.0 \\
\hline & $\begin{array}{c}\text { Strongly } \\
\text { Agree }\end{array}$ & 7 & .6 & 4.0 & 100.0 \\
\hline \multirow{3}{*}{ Missing } & Total & 177 & 14.7 & 100.0 & \\
\hline & System & 1030 & 85.3 & & \\
\hline & Total & 1207 & 100.0 & & \\
\hline
\end{tabular}


members agreed and 7 or $.6 \%$ of the faculty members strongly agreed that infusing Web 2.0 technologies within their course content is a requirement for them, 28 or $15.8 \%$ of the faculty strongly disagreed with the statement. Survey Question 29 asked the participants if there are many faculty development opportunities available to learn how to use these Web 2.0 technologies. The results of this question can be found in Table 31 .

The majority of the faculty members (63 or $35.6 \%$ ) agreed that there are many faculty development opportunities available to learn how to use these Web 2.0 technologies while 63 or $35.6 \%$ of the faculty members agreed with the statement and 55 or $31.1 \%$ of the faculty members remained neutral regarding the statement. Of the 177 participants, 35 or $19.8 \%$ disagreed and 11 or $6.2 \%$ strongly disagreed that there are many faculty development opportunities available to learn to use these Web 2.0 technologies. Survey Question 30 asked the participants if there are many faculty development programs available while they are on campus that they can sign up for to learn how to create course content utilizing Web 2.0 technologies. The results of this question can be found in Table 32 .

The majority of the faculty members (59 or $33.3 \%$ ) agreed that there are many faculty development programs available while they are on campus that they can sign up for to learn how to create course content utilizing Web 2.0 technologies and 55 or $31.1 \%$ remained neutral. While 38 or $21.5 \%$ of the faculty members disagreed with the statement and 14 or $7.9 \%$ of the faculty strongly disagreed with the statement, 11 or $6.2 \%$ of the faculty strongly agreed that there are many faculty development programs available while they are on campus that they can sign up for to learn how to create course content utilizing Web 2.0 technologies. Survey Question 31 asked the participants if the faculty development programs available on campus are based on varied proficiency levels, from beginner to expert. The results of this question can be found in Table 33.

While the majority of the faculty members (72 or $40.7 \%$ ) remained neutral, 63 or $35.6 \%$ of the faculty agreed and 11 or $6.2 \%$ strongly agreed that the faculty development programs available on campus are based on varied proficiency levels. Out of 177 participants, 23 or $13.0 \%$ disagreed and 8 or $4.5 \%$ strongly disagreed that the faculty development programs available on campus are based on varied proficiency levels. Survey Question 32 asked the participants if the faculty development opportunities on campus are effective. The results of this question can be found in Table 34.

The majority of the faculty members ( 72 or $40.7 \%$ ) agreed that the faculty development opportunities on campus are effective, while 68 or $38.4 \%$ remained neutral. Of the 177 participants, 11 or $6.2 \%$ strongly agreed with the statement, 22 or $12.4 \%$ disagreed and 4 or $2.3 \%$ strongly disagreed that the faculty development opportunities on campus are effective. Survey Question 33 asked the participants if they find it difficult to find the time to attend faculty development programs. The results of this question can be found in Table 35.

The majority of the faculty members ( 78 or $44.1 \%$ ) agreed that they find it difficult to attend faculty development programs, while 47 or $26.6 \%$ remained neutral. Of the 177 participants, 24 or $13.6 \%$ both strongly agreed and disagreed with the statement, while 4 or $2.3 \%$ strongly disagreed that they find it difficult to attend faculty development programs. Survey Question 34 asked the participants if they find it difficult to keep up with technology because it is constantly changing. The results of this question can be found in Table $\mathbf{3 6}$.
Table 31.

Frequency table - there are many faculty development opportunities available to learn how to use these Web 2.0 technologies.

\begin{tabular}{|c|c|c|c|c|c|}
\hline & & Frequency & Percent & $\begin{array}{c}\text { Valid } \\
\text { Percent }\end{array}$ & $\begin{array}{c}\text { Cumulative } \\
\text { Percent }\end{array}$ \\
\hline \multirow{5}{*}{ Valid } & $\begin{array}{l}\text { Strongly } \\
\text { Disagree }\end{array}$ & 11 & .9 & 6.2 & 6.2 \\
\hline & Disagree & 35 & 2.9 & 19.8 & 26.0 \\
\hline & Neutral & 55 & 4.6 & 31.1 & 57.1 \\
\hline & Agree & 63 & 5.2 & 35.6 & 92.7 \\
\hline & $\begin{array}{l}\text { Strongly } \\
\text { Agree }\end{array}$ & 13 & 1.1 & 7.3 & 100.0 \\
\hline \multirow{3}{*}{ Missing } & Total & 177 & 14.7 & 100.0 & \\
\hline & System & 1030 & 85.3 & & \\
\hline & Total & 1207 & 100.0 & & \\
\hline
\end{tabular}

Table 32.

Frequency table - there are many faculty development programs available while I am on campus that I can sign up for to learn how to create course content utilizing Web 2.0 technologies.

\begin{tabular}{|c|c|c|c|c|c|}
\hline & & Frequency & Percent & $\begin{array}{c}\text { Valid } \\
\text { Percent }\end{array}$ & $\begin{array}{c}\text { Cumulative } \\
\text { Percent }\end{array}$ \\
\hline \multirow{5}{*}{ Valid } & $\begin{array}{l}\text { Strongly } \\
\text { Disagree }\end{array}$ & 14 & 1.2 & 7.9 & 7.9 \\
\hline & Disagree & 38 & 3.1 & 21.5 & 29.4 \\
\hline & Neutral & 55 & 4.6 & 31.1 & 60.5 \\
\hline & Agree & 59 & 4.9 & 33.3 & 93.8 \\
\hline & $\begin{array}{c}\text { Strongly } \\
\text { Agree }\end{array}$ & 11 & .9 & 6.2 & 100.0 \\
\hline \multirow{3}{*}{ Missing } & Total & 177 & 14.7 & 100.0 & \\
\hline & System & 1030 & 85.3 & & \\
\hline & Total & 1207 & 100.0 & & \\
\hline
\end{tabular}

Table 33.

Frequency table - faculty development programs available on campus are based on varied proficiency levels, from beginner to expert.

\begin{tabular}{|c|c|c|c|c|c|}
\hline & & Frequency & Percent & $\begin{array}{c}\text { Valid } \\
\text { Percent }\end{array}$ & $\begin{array}{c}\text { Cumulative } \\
\text { Percent }\end{array}$ \\
\hline \multirow{5}{*}{ Valid } & $\begin{array}{l}\text { Strongly } \\
\text { Disagree }\end{array}$ & 8 & .7 & 4.5 & 4.5 \\
\hline & Disagree & 23 & 1.9 & 13.0 & 17.5 \\
\hline & Neutral & 72 & 6.0 & 40.7 & 58.2 \\
\hline & Agree & 63 & 5.2 & 35.6 & 93.8 \\
\hline & $\begin{array}{c}\text { Strongly } \\
\text { Agree }\end{array}$ & 11 & .9 & 6.2 & 100.0 \\
\hline \multirow{3}{*}{ Missing } & Total & 177 & 14.7 & 100.0 & \\
\hline & System & 1030 & 85.3 & & \\
\hline & Total & 1207 & 100.0 & & \\
\hline
\end{tabular}

Table 34.

Frequency table - the faculty development opportunities on campus are effective.

\begin{tabular}{|c|c|c|c|c|c|}
\hline & & Frequency & Percent & $\begin{array}{c}\text { Valid } \\
\text { Percent }\end{array}$ & $\begin{array}{c}\text { Cumulative } \\
\text { Percent }\end{array}$ \\
\hline \multirow{5}{*}{ Valid } & $\begin{array}{l}\text { Strongly } \\
\text { Disagree }\end{array}$ & 4 & .3 & 2.3 & 2.3 \\
\hline & Disagree & 22 & 1.8 & 12.4 & 14.7 \\
\hline & Neutral & 68 & 5.6 & 38.4 & 53.1 \\
\hline & Agree & 72 & 6.0 & 40.7 & 93.8 \\
\hline & $\begin{array}{l}\text { Strongly } \\
\text { Agree }\end{array}$ & 11 & .9 & 6.2 & 100.0 \\
\hline \multirow{3}{*}{ Missing } & Total & 177 & 14.7 & 100.0 & \\
\hline & System & 1030 & 85.3 & & \\
\hline & Total & 1207 & 100.0 & & \\
\hline
\end{tabular}


Table 35.

Frequency table-I find it difficult to find the time to attend faculty development programs.

\begin{tabular}{|c|c|c|c|c|c|}
\hline & & Frequency & Percent & $\begin{array}{c}\text { Valid } \\
\text { Percent }\end{array}$ & $\begin{array}{c}\text { Cumulative } \\
\text { Percent }\end{array}$ \\
\hline \multirow{5}{*}{ Valid } & $\begin{array}{l}\text { Strongly } \\
\text { Disagree }\end{array}$ & 4 & .3 & 2.3 & 2.3 \\
\hline & Disagree & 24 & 2.0 & 13.6 & 15.8 \\
\hline & Neutral & 47 & 3.9 & 26.6 & 42.4 \\
\hline & Agree & 78 & 6.5 & 44.1 & 86.4 \\
\hline & $\begin{array}{l}\text { Strongly } \\
\text { Agree }\end{array}$ & 24 & 2.0 & 13.6 & 100.0 \\
\hline \multirow{3}{*}{ Missing } & Total & 177 & 14.7 & 100.0 & \\
\hline & System & 1030 & 85.3 & & \\
\hline & Total & 1207 & 100.0 & & \\
\hline
\end{tabular}

Table 36.

Frequency table-I find it difficult to keep up with technology because it is constantly changing.

\begin{tabular}{|c|c|c|c|c|c|}
\hline & & Frequency & Percent & $\begin{array}{c}\text { Valid } \\
\text { Percent }\end{array}$ & $\begin{array}{c}\text { Cumulative } \\
\text { Percent }\end{array}$ \\
\hline \multirow{5}{*}{ Valid } & $\begin{array}{l}\text { Strongly } \\
\text { Disagree }\end{array}$ & 16 & 1.3 & 9.0 & 9.0 \\
\hline & Disagree & 38 & 3.1 & 21.5 & 30.5 \\
\hline & Neutral & 52 & 4.3 & 29.4 & 59.9 \\
\hline & Agree & 62 & 5.1 & 35.0 & 94.9 \\
\hline & $\begin{array}{l}\text { Strongly } \\
\text { Agree }\end{array}$ & 9 & .7 & 5.1 & 100.0 \\
\hline \multirow{3}{*}{ Missing } & Total & 177 & 14.7 & 100.0 & \\
\hline & System & 1030 & 85.3 & & \\
\hline & Total & 1207 & 100.0 & & \\
\hline
\end{tabular}

The majority of the faculty members (62 or $35.0 \%$ ) agreed that they find it difficult to keep up with technology because it is constantly changing, while 52 or $29.4 \%$ remained neutral. Of the 177 participants, 38 or $21.5 \%$ disagreed with the statement, while 16 or $9.0 \%$ strongly disagreed and 9 or $5.1 \%$ strongly agreed that they find it difficult to keep up with technology because it is constantly changing. Survey Question 35 asked the participants if there is adequate computer access in most classrooms they teach in. The results of this question can be found in Table 37.

The majority of the faculty members ( 72 or $40.7 \%$ ) agreed that there is adequate computer access in most classrooms they teach in. Of the 177 participants, 37 or $20.9 \%$ strongly agreed that there is adequate computer access in most classrooms they teach in, while 35 or $19.8 \%$ remained neutral, 23 or $13.0 \%$ disagreed and 10 or $5.6 \%$ strongly disagreed that there is adequate computer access in most classrooms they teach in. Survey Question 36 asked the participants if students are far more advanced in technology than they were. The results of this question can be found in Table 38.

The majority of the faculty members (63 or $35.6 \%$ ) agreed that students are far more advanced in technology than they were, while 48 or $27.1 \%$ remained neutral about the statement. Of the 177 participants, 31 or $17.5 \%$ disagreed and 14 or $7.9 \%$ strongly disagreed that students are far more advanced in technology than they were. Survey Question 37 asked the participants if it took them a long time to learn how to use Web 2.0 technologies. The results of this question can be found in Table 39.

The majority of the faculty members (59 or $33.3 \%$ ) disagreed
Table 37.

Frequency table - there is adequate computer access in most classrooms I teach in.

\begin{tabular}{|c|c|c|c|c|c|}
\hline & & Frequency & Percent & $\begin{array}{l}\text { Valid } \\
\text { Percent }\end{array}$ & $\begin{array}{c}\text { Cumulative } \\
\text { Percent }\end{array}$ \\
\hline \multirow{5}{*}{ Valid } & $\begin{array}{l}\text { Strongly } \\
\text { Disagree }\end{array}$ & 10 & .8 & 5.6 & 5.6 \\
\hline & Disagree & 23 & 1.9 & 13.0 & 18.6 \\
\hline & Neutral & 35 & 2.9 & 19.8 & 38.4 \\
\hline & Agree & 72 & 6.0 & 40.7 & 79.1 \\
\hline & $\begin{array}{l}\text { Strongly } \\
\text { Agree }\end{array}$ & 37 & 3.1 & 20.9 & 100.0 \\
\hline \multirow{3}{*}{ Missing } & Total & 177 & 14.7 & 100.0 & \\
\hline & System & 1030 & 85.3 & & \\
\hline & Total & 1207 & 100.0 & & \\
\hline
\end{tabular}

Table 38.

Frequency table - students are far more advanced in technology than I am.

\begin{tabular}{|c|c|c|c|c|c|}
\hline & & Frequency & Percent & $\begin{array}{c}\text { Valid } \\
\text { Percent }\end{array}$ & $\begin{array}{c}\text { Cumulative } \\
\text { Percent }\end{array}$ \\
\hline \multirow{5}{*}{ Valid } & $\begin{array}{l}\text { Strongly } \\
\text { Disagree }\end{array}$ & 14 & 1.2 & 7.9 & 7.9 \\
\hline & Disagree & 31 & 2.6 & 17.5 & 25.4 \\
\hline & Neutral & 48 & 4.0 & 27.1 & 52.5 \\
\hline & Agree & 63 & 5.2 & 35.6 & 88.1 \\
\hline & $\begin{array}{c}\text { Strongly } \\
\text { Agree }\end{array}$ & 21 & 1.7 & 11.9 & 100.0 \\
\hline \multirow{3}{*}{ Missing } & Total & 177 & 14.7 & 100.0 & \\
\hline & System & 1030 & 85.3 & & \\
\hline & Total & 1207 & 100.0 & & \\
\hline
\end{tabular}

Table 39.

Frequency table — it takes me a long time to learn how to use Web 2.0 technologies.

\begin{tabular}{|c|c|c|c|c|c|}
\hline & & Frequency & Percent & $\begin{array}{l}\text { Valid } \\
\text { Percent }\end{array}$ & $\begin{array}{c}\text { Cumulative } \\
\text { Percent }\end{array}$ \\
\hline \multirow{5}{*}{ Valid } & $\begin{array}{l}\text { Strongly } \\
\text { Disagree }\end{array}$ & 22 & 1.8 & 12.4 & 12.4 \\
\hline & Disagree & 59 & 4.9 & 33.3 & 45.8 \\
\hline & Neutral & 53 & 4.4 & 29.9 & 75.7 \\
\hline & Agree & 38 & 3.1 & 21.5 & 97.2 \\
\hline & $\begin{array}{l}\text { Strongly } \\
\text { Agree }\end{array}$ & 5 & .4 & 2.8 & 100.0 \\
\hline \multirow{3}{*}{ Missing } & Total & 177 & 14.7 & 100.0 & \\
\hline & System & 1030 & 85.3 & & \\
\hline & Total & 1207 & 100.0 & & \\
\hline
\end{tabular}

that it takes them a long time to learn how to use Web 2.0 technologies, while 53 or $29.9 \%$ remained neutral. Of the 177 participants, 38 or $21.5 \%$ agreed, 22 or $12.4 \%$ strongly disagreed, and 5 or $2.8 \%$ strongly agreed that it takes them a long time to learn how to use Web 2.0 technologies. Survey Question 38 asked the participants if there are many incentive or reward programs available to faculty who attend faculty development programs on campus. The results of this question can be found in Table 40.

The majority of the faculty members ( 59 or $33.3 \%$ ) disagreed that there were many incentive or reward programs available to faculty who attend faculty development programs on campus, while 57 or $32.2 \%$ remained neutral. Of the 177 participants, 38 or $21.5 \%$ strongly disagreed, 16 or $9.0 \%$ agreed, and 7 or $4.0 \%$ 
strongly agreed that there are many incentives or reward programs available to faculty who attend faculty development programs on campus. Survey Question 39 asked the participants if teaching courses utilizing Web 2.0 technologies provides more flexibility than with traditional face-to-face method. The results of this question can be found in Table 41.

The majority of the faculty members (69 or $39.0 \%$ ) agreed that teaching courses utilizing Web 2.0 technologies provides more flexibility than with the traditional face-to-face method, while 65 or $36.7 \%$ remained neutral. Of the 177 participants, 18 or $10.2 \%$ disagreed, 15 or $8.5 \%$ strongly agreed, and 10 or $5.6 \%$ strongly disagreed that teaching courses utilizing Web 2.0 technologies provides more flexibility than with traditional face-toface method. Survey Question 40 asked the participants if they were self-motivated. The results of this question can be found in Table 42.

Table 40.

Frequency table - there are many incentives or reward programs available to faculty who attend faculty development programs on campus.

\begin{tabular}{|c|c|c|c|c|c|}
\hline & & Frequency & Percent & $\begin{array}{c}\text { Valid } \\
\text { Percent }\end{array}$ & $\begin{array}{c}\text { Cumulative } \\
\text { Percent }\end{array}$ \\
\hline \multirow{5}{*}{ Valid } & $\begin{array}{l}\text { Strongly } \\
\text { Disagree }\end{array}$ & 38 & 3.1 & 21.5 & 21.5 \\
\hline & Disagree & 59 & 4.9 & 33.3 & 54.8 \\
\hline & Neutral & 57 & 4.7 & 32.2 & 87.0 \\
\hline & Agree & 16 & 1.3 & 9.0 & 96.0 \\
\hline & $\begin{array}{l}\text { Strongly } \\
\text { Agree }\end{array}$ & 7 & .6 & 4.0 & 100.0 \\
\hline \multirow{3}{*}{ Missing } & Total & 177 & 14.7 & 100.0 & \\
\hline & System & 1030 & 85.3 & & \\
\hline & Total & 1207 & 100.0 & & \\
\hline
\end{tabular}

Table 41.

Frequency table-teaching courses utilizing Web 2.0 technologies provides more flexibility than with traditional face-to-face method.

\begin{tabular}{|c|c|c|c|c|c|}
\hline & & Frequency & Percent & $\begin{array}{c}\text { Valid } \\
\text { Percent }\end{array}$ & $\begin{array}{c}\text { Cumulative } \\
\text { Percent }\end{array}$ \\
\hline \multirow{5}{*}{ Valid } & $\begin{array}{l}\text { Strongly } \\
\text { Disagree }\end{array}$ & 10 & .8 & 5.6 & 5.6 \\
\hline & Disagree & 18 & 1.5 & 10.2 & 15.8 \\
\hline & Neutral & 65 & 5.4 & 36.7 & 52.5 \\
\hline & Agree & 69 & 5.7 & 39.0 & 91.5 \\
\hline & $\begin{array}{c}\text { Strongly } \\
\text { Agree }\end{array}$ & 15 & 1.2 & 8.5 & 100.0 \\
\hline \multirow{3}{*}{ Missing } & Total & 177 & 14.7 & 100.0 & \\
\hline & System & 1030 & 85.3 & & \\
\hline & Total & 1207 & 100.0 & & \\
\hline
\end{tabular}

Table 42.

Frequency table—I am self-motivated.

\begin{tabular}{|c|c|c|c|c|c|}
\hline & & Frequency & Percent & $\begin{array}{c}\text { Valid } \\
\text { Percent }\end{array}$ & $\begin{array}{c}\text { Cumulative } \\
\text { Percent }\end{array}$ \\
\hline \multirow{5}{*}{ Valid } & $\begin{array}{l}\text { Strongly } \\
\text { Disagree }\end{array}$ & 3 & .2 & 1.7 & 1.7 \\
\hline & Disagree & 5 & .4 & 2.8 & 4.5 \\
\hline & Neutral & 22 & 1.8 & 12.4 & 16.9 \\
\hline & Agree & 86 & 7.1 & 48.6 & 65.5 \\
\hline & $\begin{array}{c}\text { Strongly } \\
\text { Agree }\end{array}$ & 61 & 5.1 & 34.5 & 100.0 \\
\hline \multirow{3}{*}{ Missing } & Total & 177 & 14.7 & 100.0 & \\
\hline & System & 1030 & 85.3 & & \\
\hline & Total & 1207 & 100.0 & & \\
\hline
\end{tabular}

The majority of the faculty members ( 86 or $48.6 \%$ ) agreed that they were self-motivated and 61 or $34.5 \%$ strongly agreed that they were self-motivated. Of the 177 participants, 22 or $12.4 \%$ remained neutral, 5 or $2.8 \%$ disagreed, and 3 or $1.7 \%$ strongly disagree that they were self-motivated.

\section{Research Questions}

The research study had one primary research question and six secondary research question. The hypotheses statements that support the primary and secondary research questions were:

The primary research question for this study was:

To what extent do faculty members teaching college courses utilizing Web 2.0 technologies perceive that this method is a practical alternative to the traditional classroom method?

The supporting hypothesis statements for the primary research question were:

$\mathrm{H}_{0}=$ There is no relationship between faculty members' perception of teaching college courses utilizing Web 2.0 technologies versus the traditional classroom method.

$\mathrm{H} 1_{1}=$ There is a relationship between faculty members' perception of teaching college courses utilizing Web 2.0 technologies versus the traditional classroom method.

The survey questions related to this research question were the following:

- Survey Question 6: Do you teach undergraduate or graduate courses?

- Survey Question 7: Do you teach traditional face-to-face, hybrid, or online courses?

- Survey Question 22: Using Web 2.0 technologies improves the quality of my teaching.

- Survey Question 23: Using Web 2.0 technologies enhances the student's experiences in the classroom.

- Survey Question 27: There are no differences in what I taught utilizing Web 2.0 technologies versus the traditional classroom method.

- Survey Question 39: Teaching courses utilizing Web 2.0 technologies provides more flexibility than with the traditional face-to-face method.

A non-parametric Chi-squared test was completed to determine the extent to which faculty members perception of teaching college courses utilizing Web 2.0 technologies as a practical alternative to the traditional classroom method differ from the neutral point. Chi-square tests are used to evaluate whether or not differences between the observed and expected frequencies are due to chance alone or to something more than simple errors. The results of the chi-square test can be found in Table 43.

As indicated in Table 43, the minimum expected cell frequencies are significantly less than the chi-square values and the two-sided observed significance level on the Chi-Square (Asymp. Sig) are less than the customary .05 the null hypothesis is rejected. A Non-Parametric Chi-Square Hypothesis Test Summary was conducted also test the decision. The results can be found in Table 44 .

The results in Table $\mathbf{4 4}$ confirm the rejection of the null hypothesis. There was a significant difference between faculty members' perception of teaching college courses utilizing Web 2.0 technologies versus the traditional classroom method. Therefore, the alternate hypothesis is accepted: there is a relationship between faculty members' perception of teaching college courses utilizing Web 2.0 technologies versus the traditional classroom 
Table 43.

Non-parametric chi-square test statistics.

\begin{tabular}{|c|c|c|c|c|c|c|}
\hline & $\begin{array}{l}\text { 6. Do you teach } \\
\text { undergraduate or } \\
\text { graduate courses? }\end{array}$ & $\begin{array}{l}\text { 7. Do you teach } \\
\text { traditional face-to-face, } \\
\text { hybrid, or online } \\
\text { courses? }\end{array}$ & $\begin{array}{l}\text { 22. Using Web } 2.0 \\
\text { technologies improves } \\
\text { the quality of my } \\
\text { teaching }\end{array}$ & $\begin{array}{l}\text { 23. Using Web } 2.0 \\
\text { technologies enhances } \\
\text { the student's } \\
\text { experiences in the } \\
\text { classroom }\end{array}$ & $\begin{array}{l}\text { 27. There are no } \\
\text { differences in what I } \\
\text { taught utilizing Web } 2.0 \\
\text { technologies versus the } \\
\text { traditional classroom } \\
\text { method }\end{array}$ & $\begin{array}{l}\text { 39. Teaching courses } \\
\text { utilizing Web } 2.0 \\
\text { technologies provides } \\
\text { more flexibility } t \text { ) han } \\
\text { with the traditional } \\
\text { face-to-face method }\end{array}$ \\
\hline Chi-Square & $83.932^{\mathrm{a}}$ & $153.554^{b}$ & $141.164^{c}$ & $138.169^{c}$ & $67.266^{\mathrm{c}}$ & $95.175^{\mathrm{c}}$ \\
\hline Df & 2 & 3 & 4 & 4 & 4 & 4 \\
\hline Asymp. Sig. & .000 & .000 & .000 & .000 & .000 & .000 \\
\hline
\end{tabular}

Note. 0 cells $(.0 \%)$ have expected frequencies less than 5 . The minimum expected cell frequency is $59.0 ;$ Note. 0 cells $(.0 \%)$ have expected frequencies less than 5 . The minimum expected cell frequency is 44.3 ; Note. 0 cells $(.0 \%)$ have expected frequencies less than 5 . The minimum expected cell frequency is 35.4 .

Table 44.

Non-parametric chi-square hypothesis test summary.

\begin{tabular}{lcc}
\hline \multicolumn{1}{c}{ Null Hypothesis } & Test & \multicolumn{1}{c}{ Decision } \\
$\begin{array}{l}\text { The categories of Teaching courses utilizing Web } 2.0 \text { technologies provides more flexibility } \\
\text { than with the traditional face-to-face method occur with equal probabilities. }\end{array}$ & One-Sample Chi-Square Test $\quad .000 \quad$ Reject the null hypothesis. \\
$\begin{array}{l}\text { The categories of There are no differences in what I taught utilizing Web } 2.0 \text { technologies } \\
\text { versus the traditional classroom occur with equal probabilities. }\end{array}$ & One-Sample Chi-Square Test $\quad .000 \quad$ Reject the null hypothesis. \\
$\begin{array}{l}\text { The categories of Using Web } 2.0 \text { technologies improves the quality my teaching occur with } \\
\text { equal probabilities. }\end{array}$ & One-Sample Chi-Square Test $\quad .000 \quad$ Reject the null hypothesis. \\
$\begin{array}{l}\text { The categories of Using Web } 2.0 \text { technologies enhances the student's experiences in the } \\
\text { classroom occur with equal probabilities. }\end{array}$ & One-Sample Chi-Square Test $\quad .000 \quad$ Reject the null hypothesis. \\
$\begin{array}{l}\text { The categories of Do you teach undergraduate or graduate courses occur with equal } \\
\text { probabilities. }\end{array}$ & One-Sample Chi-Square Test $\quad .000 \quad$ Reject the null hypothesis. \\
$\begin{array}{l}\text { The categories of Do you teach traditional face-to-face, hybrid, or online course? occur with } \\
\text { equal probabilities. }\end{array}$ & One-Sample Chi-Square Test $\quad .000 \quad$ Reject the null hypothesis. \\
\hline
\end{tabular}

Note. Asymptotic significance are displayed. The significance level is .05.

method.

The second research question for this study was:

To what extent do faculty members perceive that there is an adequate level of development programs available to create their course content utilizing Web 2.0 technologies?

The supporting hypothesis statements for the second research question were:

$\mathrm{H} 2_{0}=$ There is no relationship between faculty members' perception of the level of development programs and the creation of course content utilizing Web 2.0 technologies.

$\mathrm{H} 2{ }_{1}=$ There is a relationship between faculty members' perception of the level of development programs and the creation of course content utilizing Web 2.0 technologies.

The survey questions related to this research question were the following:

- Survey Question 12: Specifically to the Web 2.0 technologies that your University offers, how technically proficient do you consider yourself to be?

- Survey Question 29: There are many faculty development opportunities available to learn how to use these Web 2.0 technologies.

- Survey Question 30: There are many faculty development programs available while I am on campus that I can sign up for to learn how to create course content utilizing Web 2.0 technologies.

- Survey Question 31: The faculty development programs available on campus are based on varied proficiency levels, from beginner to expert.

To test these hypotheses, a One Way ANOVA was conducted on the survey questions related to faculty development programs based on gender was conducted. The results can be found in Table 45.

As Table 45 indicates, the $p$-values (Sig.) are .764, .224, .083, and .104 respectively. When the $p$-value is less than the commonly accepted .05 value, we reject the null hypothesis. In this case all of the $p$-values are greater than .05 . That said, the null hypothesis is not rejected. There was no significant different between faculty members' perception based on gender of the level of development programs and the creation of course content utilizing Web 2.0 technologies. Therefore, the null hypothesis is accepted. There is no relationship between faculty members' perception of the level of development programs and the creation of course content utilizing Web 2.0 technologies.

An additional One Way ANOVA was conducted on the survey questions related to faculty development programs based on age was conducted. The results can be seen in Table $\mathbf{4 6}$.

As Table 46 indicates, the $p$-values (Sig.) are .024, .053, .086, and .732 respectively. When the $p$-value is less than the commonly accepted .05 value, we reject the null hypothesis. In this case all of the $p$-values are greater than .05 except for one. That said, we do not reject the null hypothesis. There was no significant difference between faculty members' perception based on age of the level of development programs and the creation of course content utilizing Web 2.0 technologies. Therefore, the null hypothesis is accepted. There is no relationship between faculty members' perception of the level of development programs and the creation of course content utilizing Web 2.0 technologies.

A third One Way ANOVA was conducted on the survey questions related to faculty development programs based on employment status was conducted. The results can be seen in Table 47. 
Table 45.

One way ANOVA test based on gender.

\begin{tabular}{|c|c|c|c|c|c|c|}
\hline & & Sum of Squares & $\mathrm{df}$ & Mean Square & $\mathrm{F}$ & Sig. \\
\hline \multirow{3}{*}{$\begin{array}{l}\text { 12. Specifically to the Web } 2.0 \text { technologies that your University offers, how } \\
\text { technically proficient do you consider yourself to be? }\end{array}$} & Between Groups & .123 & 1 & .123 & .090 & .764 \\
\hline & Within Groups & 238.431 & 175 & 1.362 & & \\
\hline & Total & 238.554 & 176 & & & \\
\hline \multirow{3}{*}{$\begin{array}{l}\text { 29. There are many faculty development opportunities available to learn how to use } \\
\text { these Web } 2.0 \text { technologies }\end{array}$} & Between Groups & 1.589 & 1 & 1.589 & 1.490 & .224 \\
\hline & Within Groups & 186.625 & 175 & 1.066 & & \\
\hline & Total & 188.215 & 176 & & & \\
\hline \multirow{3}{*}{$\begin{array}{l}\text { 30. There are many faculty development programs available while I am on campus } \\
\text { that I can sign up for to learn how to create course content utilizing Web } 2.0 \\
\text { technologies }\end{array}$} & Between Groups & 3.352 & 1 & 3.352 & 3.049 & .083 \\
\hline & Within Groups & 192.377 & 175 & 1.099 & & \\
\hline & Total & 195.729 & 176 & & & \\
\hline \multirow{3}{*}{$\begin{array}{l}\text { 31. The faculty development programs available on campus are based on varied } \\
\text { proficiency levels, from beginner to expert }\end{array}$} & Between Groups & 2.253 & 1 & 2.253 & 2.668 & .104 \\
\hline & Within Groups & 147.792 & 175 & .845 & & \\
\hline & Total & 150.045 & 176 & & & \\
\hline
\end{tabular}

Table 46.

One way ANOVA test based on age.

\begin{tabular}{|c|c|c|c|c|c|c|}
\hline & & Sum of Squares & df & Mean Square & $\mathrm{F}$ & Sig. \\
\hline \multirow{2}{*}{$\begin{array}{l}\text { 12. Specifically to the Web } 2.0 \text { technologies that your University offers, how } \\
\text { technically proficient do you consider yourself to be? }\end{array}$} & Between Groups & 17.255 & 5 & 3.451 & 2.667 & .024 \\
\hline & Within Groups & 221.298 & 171 & 1.294 & & \\
\hline \multirow{3}{*}{$\begin{array}{l}\text { 29. There are many faculty development opportunities available to learn how to use } \\
\text { these Web } 2.0 \text { technologies }\end{array}$} & Between Groups & 11.552 & 5 & 2.310 & 2.236 & .053 \\
\hline & Within Groups & 176.663 & 171 & 1.033 & & \\
\hline & Total & 188.215 & 176 & & & \\
\hline \multirow{3}{*}{$\begin{array}{l}\text { 30. There are many faculty development programs available while I am on campus } \\
\text { that I can sign up for to learn how to create course content utilizing Web } 2.0 \\
\text { technologies }\end{array}$} & Between Groups & 10.628 & 5 & 2.126 & 1.964 & .086 \\
\hline & Within Groups & 185.101 & 171 & 1.082 & & \\
\hline & Total & 195.729 & 176 & & & \\
\hline \multirow{3}{*}{$\begin{array}{l}\text { 31. The faculty development programs available on campus are based on varied } \\
\text { proficiency levels, from beginner to expert }\end{array}$} & Between Groups & 2.408 & 5 & .482 & .558 & .732 \\
\hline & Within Groups & 147.637 & 171 & .863 & & \\
\hline & Total & 150.045 & 176 & & & \\
\hline
\end{tabular}

Table 47.

One way ANOVA test based on employment status.

\begin{tabular}{|c|c|c|c|c|c|c|}
\hline & & Sum of Squares & df & Mean Square & $\mathrm{F}$ & Sig. \\
\hline \multirow{3}{*}{$\begin{array}{l}\text { 12. Specifically to the Web } 2.0 \text { technologies that your University offers, how } \\
\text { technically proficient do you consider yourself to be? }\end{array}$} & Between Groups & 13.460 & 6 & 2.243 & 1.694 & .125 \\
\hline & Within Groups & 225.093 & 170 & 1.324 & & \\
\hline & Total & 238.554 & 176 & & & \\
\hline \multirow{3}{*}{$\begin{array}{l}\text { 29. There are many faculty development opportunities available to learn how to use } \\
\text { these Web } 2.0 \text { technologies }\end{array}$} & Between Groups & 3.335 & 6 & .556 & .511 & .799 \\
\hline & Within Groups & 184.880 & 170 & 1.088 & & \\
\hline & Total & 188.215 & 176 & & & \\
\hline \multirow{3}{*}{$\begin{array}{l}\text { 30. There are many faculty development programs available while I am on campus } \\
\text { that I can sign up for to learn how to create course content utilizing Web } 2.0 \\
\text { technologies }\end{array}$} & Between Groups & 3.798 & 6 & .633 & .561 & .761 \\
\hline & Within Groups & 191.931 & 170 & 1.129 & & \\
\hline & Total & 195.729 & 176 & & & \\
\hline \multirow{3}{*}{$\begin{array}{l}\text { 31. The faculty development programs available on campus are based on varied } \\
\text { proficiency levels, from beginner to expert }\end{array}$} & Between Groups & 6.200 & 6 & 1.033 & 1.221 & .298 \\
\hline & Within Groups & 143.845 & 170 & .846 & & \\
\hline & Total & 150.045 & 176 & & & \\
\hline
\end{tabular}

Table 47 indicates that the $p$-values (Sig.) are $.125, .799, .761$, and .298 respectively. When the $p$-value is less than the commonly accepted .05 value, we reject the null hypothesis. In this case all of the $p$-values are greater than .05. That said, we do not reject the null hypothesis. There was no significant difference between faculty members' perception based on employment status of the level of development programs and the creation of course content utilizing Web 2.0 technologies. Therefore, the null hypothesis is accepted. There is no relationship be- tween faculty members' perception of the level of development programs and the creation of course content utilizing Web 2.0 technologies.

The third research question was:

To what extent do faculty members perceive that the faculty development programs affecting technology integration are effective?

The supporting hypothesis statements for the third research question were: 
$\mathrm{H} 3_{0}=$ There is no relationship between faculty members' perception of development programs affecting technology integration and their effectiveness.

$\mathrm{H} 3_{1}=$ There is a relationship between faculty members' perception of development programs affecting technology integration and their effectiveness.

The survey questions related to this research question were the following:

- Survey Question 14: Blogs;

- Survey Question 15: Facebook;

- Survey Question 16: Podcast;

- Survey Question 17: Second Life;

- Survey Question 18: Skype;

- Survey Question 19: Twitter;

- Survey Question 20: Wiki;

- Survey Question 21: YouTube;

- Survey Question 32: The faculty development opportunities on campus are effective.

To test these hypotheses, a One Way ANOVA of the Web 2.0 technologies survey questions based on gender was conducted. The results can be seen in Table 48 .

As Table 48 indicates, the $p$-values (Sig.) are $.809, .819, .991$, $.163, .857, .935, .848, .005$, and .089 respectively. When the $p$-value is less than the commonly accepted .05 value, we reject the null hypothesis. In this case all of the $p$-values are greater than .05 except for one. That said, the null hypothesis is not rejected. There was no significant difference between faculty members' perception based on gender of development pro- grams affecting technology and their effectiveness. Therefore, the null hypothesis is accepted. There is no relationship between faculty members' perception of development programs affecting technology integration and their effectiveness.

An additional One Way ANOVA of the Web 2.0 technologies survey questions based on employment status was conducted. The results can be seen in Table 49.

As Table 49 indicates, the $p$-values (Sig.) are .088, .151, .259, $.081, .039, .002, .249, .077$, and .366 respectively. When the $p$-value is less than the commonly accepted .05 value, the null hypothesis is not rejected. In this case all of the $p$-values are greater than .05 except for two. That said, the null hypothesis is not rejected. There was no significant difference between faculty members' perception based on employment status of development programs affecting technology integration and their effectiveness. Therefore, the null hypothesis is accepted. There is no relationship between faculty members' perception of development programs affecting technology integration and their effectiveness.

The fourth research question was:

To what extent do faculty members perceive that the impact of the barriers affecting technology integration is hindering their ability to utilize Web 2.0 technologies?

The supporting hypothesis statements for the fourth research question were:

$\mathrm{H} 4_{0}=$ There is no relationship between faculty members' perception of the impact of the barriers affecting technology integration and the faculty members' ability to utilize Web 2.0

Table 48.

One way ANOVA test based on gender.

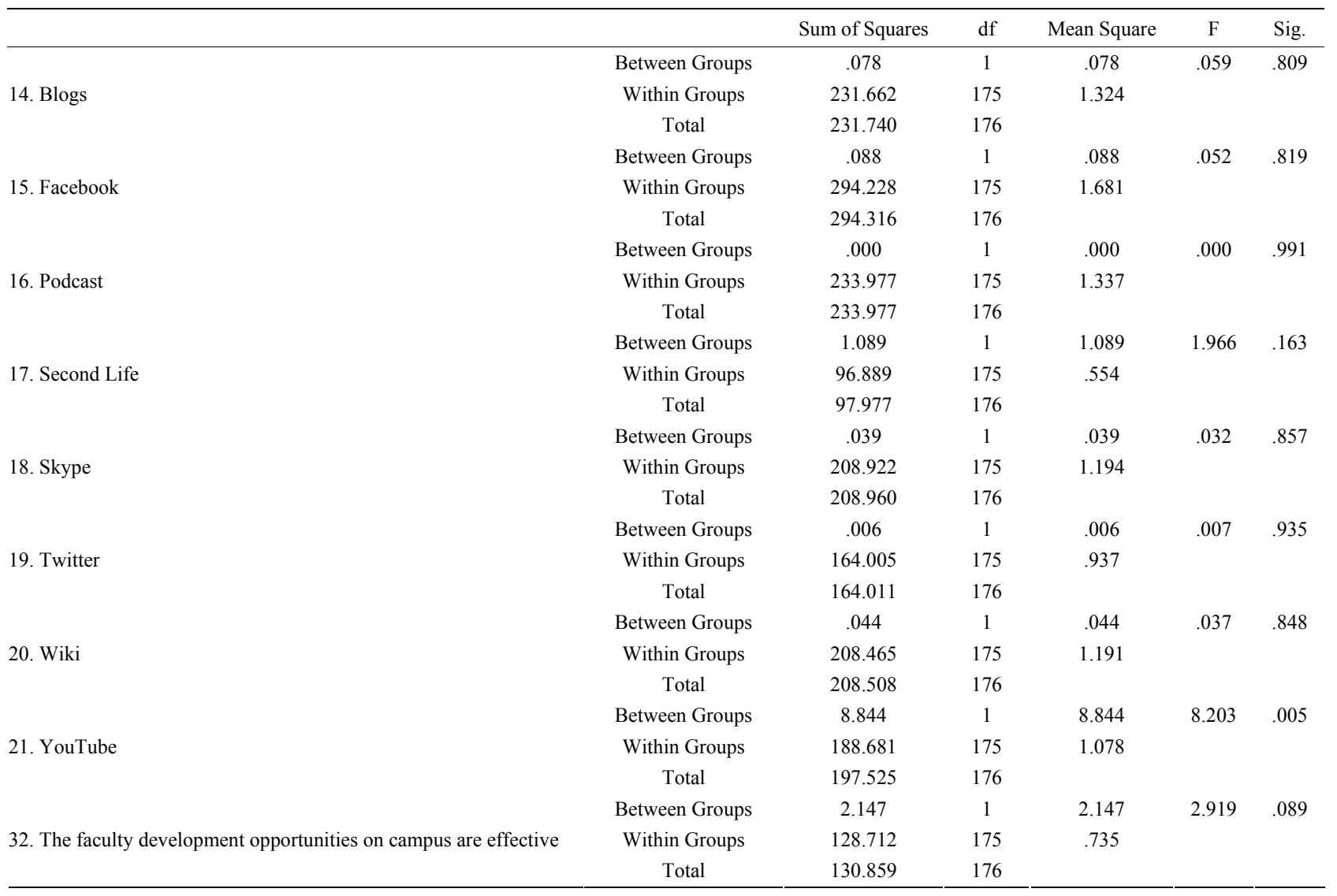


Table 49.

One way ANOVA test based on employment status.

\begin{tabular}{|c|c|c|c|c|c|c|}
\hline & & Sum of Squares & df & Mean Square & F & Sig. \\
\hline \multirow{3}{*}{ 14. Blogs } & Between Groups & 14.366 & 6 & 2.394 & 1.872 & .088 \\
\hline & Within Groups & 217.374 & 170 & 1.279 & & \\
\hline & Total & 231.740 & 176 & & & \\
\hline \multirow{3}{*}{ 15. Facebook } & Between Groups & 15.708 & 6 & 2.618 & 1.597 & .151 \\
\hline & Within Groups & 278.608 & 170 & 1.639 & & \\
\hline & Total & 294.316 & 176 & & & \\
\hline \multirow{3}{*}{ 16. Podcast } & Between Groups & 10.275 & 6 & 1.712 & 1.301 & .259 \\
\hline & Within Groups & 223.702 & 170 & 1.316 & & \\
\hline & Total & 233.977 & 176 & & & \\
\hline \multirow{3}{*}{ 17. Second Life } & Between Groups & 6.202 & 6 & 1.034 & 1.915 & .081 \\
\hline & Within Groups & 91.776 & 170 & .540 & & \\
\hline & Total & 97.977 & 176 & & & \\
\hline \multirow{3}{*}{ 18. Skype } & Between Groups & 15.534 & 6 & 2.589 & 2.275 & .039 \\
\hline & Within Groups & 193.427 & 170 & 1.138 & & \\
\hline & Total & 208.960 & 176 & & & \\
\hline \multirow{3}{*}{ 19. Twitter } & Between Groups & 18.581 & 6 & 3.097 & 3.620 & .002 \\
\hline & Within Groups & 145.430 & 170 & .855 & & \\
\hline & Total & 164.011 & 176 & & & \\
\hline \multirow{3}{*}{ 20. Wiki } & Between Groups & 9.314 & 6 & 1.552 & 1.325 & 249 \\
\hline & Within Groups & 199.194 & 170 & 1.172 & & \\
\hline & Total & 208.508 & 176 & & & \\
\hline \multirow{3}{*}{ 21. YouTube } & Between Groups & 12.673 & 6 & 2.112 & 1.943 & .077 \\
\hline & Within Groups & 184.852 & 170 & 1.087 & & \\
\hline & Total & 197.525 & 176 & & & \\
\hline \multirow{3}{*}{ 32. The faculty development opportunities on campus are effective } & Between Groups & 4.879 & 6 & .813 & 1.097 & .366 \\
\hline & Within Groups & 125.979 & 170 & .741 & & \\
\hline & Total & 130.859 & 176 & & & \\
\hline
\end{tabular}

technologies.

$\mathrm{H} 4_{1}=$ There is a relationship between faculty members' perception of the impact of the barriers affecting technology integration and the faculty members' ability to utilize Web 2.0 technologies.

The survey questions related to this research question were the following:

- Survey Question 8: Do you prefer to teach traditional faceto-face, hybrid, or online courses?

- Survey Question 9: Do you have a personal (home) computer?

- Survey Question 10: do you have a computer issued from the University?

- Survey Question 11: In general, how technically proficient do you consider yourself to be?

- Survey Question 13: In general, I learn best by.

- Survey Question 24: Learning to use Web 2.0 technologies is easy for me.

- Survey Question 25: Learning to use Web 2.0 technologies is beneficial to me as a faculty member in higher education.

- Survey Question 26: My students expect me to use Web 2.0 technology for instruction.

- Survey Question 28: Infusing Web 2.0 technologies within my course content is a requirement for me.

- Survey Question 33: I find it difficult to find the time to attend faculty development programs.

- Survey Question 34: I find it difficult to keep up with technology because it is constantly changing.
- Survey Question 35: There is adequate computer access in most classrooms I teach in.

- Survey Question 36: Students are far more advanced in technology than I am.

- Survey Question 37: It takes me a long time to learn how to use Web 2.0 technologies.

- Survey Question 38: There are many incentives or reward programs available to faulty who attend faculty development programs on campus.

- Survey Question 40: I am self-motivated.

To test these hypotheses, a One Way ANOVA of survey questions relating to barriers based on gender. The results can be found in Table $\mathbf{5 0}$.

As Table 50 indicates, the $p$-values (Sig.) are .092, .520, .887, $.464, .599, .170, .000, .073, .099, .998, .444, .581, .508, .152$, .892 , and .117 respectively. When the $p$-value is less than the commonly accepted .05 value, we reject the null hypothesis. In this case all of the $p$-values are greater than .05 except for one. That said, the null hypothesis is not rejected. There was no significant difference between faculty members' perception based on gender of the impact of the barriers affecting technology integration and the faculty members' ability to utilize Web 2.0 technologies. Therefore, the null hypothesis is accepted. There is no relationship between faculty members' perception of the impact of the barriers affecting technology integration and the faculty members' ability to utilize Web 2.0 technologies.

An additional One Way ANOVA of survey questions relating to barriers based age was also conducted. The results can be 
Table 50.

One way ANOVA test based on gender.

\begin{tabular}{|c|c|c|c|c|c|c|}
\hline & & Sum of Squares & df & Mean Square & $\mathrm{F}$ & Sig. \\
\hline \multirow{3}{*}{ 8. Do you prefer to teach traditional face-to-face, hybrid, or online courses? } & Between Groups & 3.561 & 1 & 3.561 & 2.873 & .092 \\
\hline & Within Groups & 216.958 & 175 & 1.240 & & \\
\hline & Total & 220.520 & 176 & & & \\
\hline \multirow{3}{*}{ 9. Do you have a personal (home) computer? } & Between Groups & .012 & 1 & .012 & .416 & .520 \\
\hline & Within Groups & 4.847 & 175 & .028 & & \\
\hline & Total & 4.859 & 176 & & & \\
\hline \multirow{3}{*}{ 10. Do you have a computer issued from the University? } & Between Groups & .005 & 1 & .005 & .020 & .887 \\
\hline & Within Groups & 44.006 & 175 & .251 & & \\
\hline & Total & 44.011 & 176 & & & \\
\hline \multirow{3}{*}{ 11. In general, how technically proficient do you consider yourself to be? } & Between Groups & .624 & 1 & .624 & .539 & .464 \\
\hline & Within Groups & 202.878 & 175 & 1.159 & & \\
\hline & Total & 203.503 & 176 & & & \\
\hline \multirow{3}{*}{ 13. In general, I learn best by } & Between Groups & .249 & 1 & .249 & .278 & .599 \\
\hline & Within Groups & 156.712 & 175 & .895 & & \\
\hline & Total & 156.960 & 176 & & & \\
\hline \multirow{3}{*}{ 24. Learning to use Web 2.0 technologies is easy for me } & Between Groups & 1.538 & 1 & 1.538 & 1.898 & .170 \\
\hline & Within Groups & 141.829 & 175 & .810 & & \\
\hline & Total & 143.367 & 176 & & & \\
\hline \multirow{3}{*}{$\begin{array}{l}\text { 25. Learning to use Web } 2.0 \text { technologies is beneficial to me as a faculty member in } \\
\text { higher education }\end{array}$} & Between Groups & 13.616 & 1 & 13.616 & 19.209 & .000 \\
\hline & Within Groups & 124.045 & 175 & .709 & & \\
\hline & Total & 137.661 & 176 & & & \\
\hline \multirow{3}{*}{ 26. My students expect me to use Web 2.0 technology for instruction } & Between Groups & 3.104 & 1 & 3.104 & 3.244 & .073 \\
\hline & Within Groups & 167.449 & 175 & .957 & & \\
\hline & Total & 170.554 & 176 & & & \\
\hline \multirow{3}{*}{ 28. Infusing Web 2.0 technologies within my course content is a requirement for me } & Between Groups & 3.278 & 1 & 3.278 & 2.757 & .099 \\
\hline & Within Groups & 208.056 & 175 & 1.189 & & \\
\hline & Total & 211.333 & 176 & & & \\
\hline \multirow{3}{*}{ 33. I find it difficult to find the time to attend faculty development programs } & Between Groups & .000 & 1 & .000 & .000 & 998 \\
\hline & Within Groups & 164.079 & 175 & .938 & & \\
\hline & Total & 164.079 & 176 & & & \\
\hline \multirow{3}{*}{ 34. I find it difficult to keep up with technology because it is constantly changing } & Between Groups & .670 & 1 & 670 & .590 & .444 \\
\hline & Within Groups & 198.765 & 175 & 1.136 & & \\
\hline & Total & 199.435 & 176 & & & \\
\hline \multirow{3}{*}{ 35. There is adequate computer access in most classrooms I teach in } & Between Groups & .389 & 1 & .389 & .306 & .581 \\
\hline & Within Groups & 222.673 & 175 & 1.272 & & \\
\hline & Total & 223.062 & 176 & & & \\
\hline \multirow{3}{*}{ 36. Students are far more advanced in technology than I am } & Between Groups & .558 & 1 & .558 & .441 & .508 \\
\hline & Within Groups & 221.488 & 175 & 1.266 & & \\
\hline & Total & 222.045 & 176 & & & \\
\hline \multirow{3}{*}{ 37. It takes me a long time to learn how to use Web 2.0 technologies } & Between Groups & 2.200 & 1 & 2.200 & 2.073 & .152 \\
\hline & Within Groups & 185.710 & 175 & 1.061 & & \\
\hline & Total & 187.910 & 176 & & & \\
\hline \multirow{3}{*}{$\begin{array}{l}\text { 38. There are many incentives or reward programs available to faculty who attend } \\
\text { faculty development programs on campus }\end{array}$} & Between Groups & .021 & 1 & .021 & .019 & .892 \\
\hline & Within Groups & 192.691 & 175 & 1.101 & & \\
\hline & Total & 192.712 & 176 & & & \\
\hline \multirow{3}{*}{ 40. I am self-motivated } & Between Groups & 1.782 & 1 & 1.782 & 2.476 & .117 \\
\hline & Within Groups & 125.958 & 175 & .720 & & \\
\hline & Total & 127.740 & 176 & & & \\
\hline
\end{tabular}

found in Table 51.

As Table 51 indicates, the $p$-values (Sig.) are .527, .209, .185, $.295, .293, .011, .027, .111, .114, .750, .187, .007, .012, .430$, .091 , and .010 respectively. When the $p$-value is less than the commonly accepted .05 value, we reject the null hypothesis. In this case all of the $p$-values are greater than .05 except for five That said, the null hypothesis is not rejected. There was no significant difference between faculty members' perception based on age of the impact of the barriers affecting technology integration and the faculty members' ability to utilize Web 2.0 
Table 51.

One way ANOVA test based on age.

\begin{tabular}{|c|c|c|c|c|c|c|}
\hline & & Sum of Squares & df & Mean Square & $\mathrm{F}$ & Sig. \\
\hline \multirow{3}{*}{ 8. Do you prefer to teach traditional face-to-face, hybrid, or online courses? } & Between Groups & 5.255 & 5 & 1.051 & .835 & .527 \\
\hline & Within Groups & 215.265 & 171 & 1.259 & & \\
\hline & Total & 220.520 & 176 & & & \\
\hline \multirow{3}{*}{ 9. Do you have a personal (home) computer? } & Between Groups & .197 & 5 & .039 & 1.449 & 209 \\
\hline & Within Groups & 4.661 & 171 & .027 & & \\
\hline & Total & 4.859 & 176 & & & \\
\hline \multirow{3}{*}{ 10. Do you have a computer issued from the University? } & Between Groups & 1.876 & 5 & .375 & 1.523 & 185 \\
\hline & Within Groups & 42.135 & 171 & 246 & & \\
\hline & Total & 44.011 & 176 & & & \\
\hline \multirow{3}{*}{ 11. In general, how technically proficient do you consider yourself to be? } & Between Groups & 7.088 & 5 & 1.418 & 1.234 & .295 \\
\hline & Within Groups & 196.414 & 171 & 1.149 & & \\
\hline & Total & 203.503 & 176 & & & \\
\hline \multirow{3}{*}{ 13. In general, I learn best by } & Between Groups & 5.488 & 5 & 1.098 & 1.239 & .293 \\
\hline & Within Groups & 151.472 & 171 & .886 & & \\
\hline & Total & 156.960 & 176 & & & \\
\hline \multirow{3}{*}{ 24. Learning to use Web 2.0 technologies is easy for me } & Between Groups & 11.764 & 5 & 2.353 & 3.057 & .011 \\
\hline & Within Groups & 131.603 & 171 & .770 & & \\
\hline & Total & 143.367 & 176 & & & \\
\hline \multirow{3}{*}{$\begin{array}{l}\text { 25. Learning to use Web } 2.0 \text { technologies is beneficial to me as a faculty member in } \\
\text { higher education }\end{array}$} & Between Groups & 9.705 & 5 & 1.941 & 2.594 & .027 \\
\hline & Within Groups & 127.956 & 171 & .748 & & \\
\hline & Total & 137.661 & 176 & & & \\
\hline \multirow{3}{*}{ 26. My students expect me to use Web 2.0 technology for instruction } & Between Groups & 8.626 & 5 & 1.725 & 1.822 & .111 \\
\hline & Within Groups & 161.927 & 171 & .947 & & \\
\hline & Total & 170.554 & 176 & & & \\
\hline \multirow{3}{*}{ 28. Infusing Web 2.0 technologies within my course content is a requirement for me } & Between Groups & 10.616 & 5 & 2.123 & 1.809 & .114 \\
\hline & Within Groups & 200.717 & 171 & 1.174 & & \\
\hline & Total & 211.333 & 176 & & & \\
\hline \multirow{3}{*}{ 33. I find it difficult to find the time to attend faculty development programs } & Between Groups & 2.525 & 5 & .505 & .534 & .750 \\
\hline & Within Groups & 161.554 & 171 & .945 & & \\
\hline & Total & 164.079 & 176 & & & \\
\hline \multirow{3}{*}{ 34. I find it difficult to keep up with technology because it is constantly changing } & Between Groups & 8.468 & 5 & 1.694 & 1.517 & .187 \\
\hline & Within Groups & 190.967 & 171 & 1.117 & & \\
\hline & Total & 199.435 & 176 & & & \\
\hline \multirow{3}{*}{ 35. There is adequate computer access in most classrooms I teach in } & Between Groups & 19.724 & 5 & 3.945 & 3.317 & .007 \\
\hline & Within Groups & 203.338 & 171 & 1.189 & & \\
\hline & Total & 223.062 & 176 & & & \\
\hline \multirow{3}{*}{ 36. Students are far more advanced in technology than I am } & Between Groups & 17.986 & 5 & 3.597 & 3.014 & .012 \\
\hline & Within Groups & 204.060 & 171 & 1.193 & & \\
\hline & Total & 222.045 & 176 & & & \\
\hline \multirow{3}{*}{ 37. It takes me a long time to learn how to use Web 2.0 technologies } & Between Groups & 5.251 & 5 & 1.050 & .983 & .430 \\
\hline & Within Groups & 182.658 & 171 & 1.068 & & \\
\hline & Total & 187.910 & 176 & & & \\
\hline \multirow{3}{*}{$\begin{array}{l}\text { 38. There are many incentives or reward programs available to faculty who attend } \\
\text { faculty development programs on campus }\end{array}$} & Between Groups & 10.314 & 5 & 2.063 & 1.934 & .091 \\
\hline & Within Groups & 182.398 & 171 & 1.067 & & \\
\hline & Total & 192.712 & 176 & & & \\
\hline \multirow{3}{*}{ 40. I am self-motivated } & Between Groups & 10.729 & 5 & 2.146 & 3.136 & .010 \\
\hline & Within Groups & 117.011 & 171 & .684 & & \\
\hline & Total & 127.740 & 176 & & & \\
\hline
\end{tabular}

technologies. Therefore, the null hypothesis is accepted. There is no relationship between faculty members' perception of the impact of the barriers affecting technology integration and the faculty members' ability to utilize Web 2.0 technologies.

A third One Way ANOVA of survey questions relating to barriers based on employment status was also conducted. The results can be seen in Table 52 .

Table 52 reflects the majority of the $p$-values being greater than .05 . That said, we do not reject the null hypothesis. There was no significant difference between faculty members' per- 
Table 52.

One way ANOVA test based on employment status.

\begin{tabular}{|c|c|c|c|c|c|c|}
\hline & & Sum of Squares & df & Mean Square & $\mathrm{F}$ & Sig. \\
\hline \multirow{3}{*}{ 8. Do you prefer to teach traditional face-to-face, hybrid, or online courses? } & Between Groups & 7.047 & 6 & 1.174 & .935 & .471 \\
\hline & Within Groups & 213.473 & 170 & 1.256 & & \\
\hline & Total & 220.520 & 176 & & & \\
\hline \multirow{3}{*}{ 9. Do you have a personal (home) computer? } & Between Groups & .972 & 6 & .162 & 7.088 & .000 \\
\hline & Within Groups & 3.886 & 170 & .023 & & \\
\hline & Total & 4.859 & 176 & & & \\
\hline \multirow{3}{*}{ 10. Do you have a computer issued from the University? } & Between Groups & 12.068 & 6 & 2.011 & 10.705 & .000 \\
\hline & Within Groups & 31.943 & 170 & .188 & & \\
\hline & Total & 44.011 & 176 & & & \\
\hline \multirow{3}{*}{ 11. In general, how technically proficient do you consider yourself to be? } & Between Groups & 3.332 & 6 & .555 & .472 & .829 \\
\hline & Within Groups & 200.171 & 170 & 1.177 & & \\
\hline & Total & 203.503 & 176 & & & \\
\hline \multirow{3}{*}{ 13. In general, I learn best by } & Between Groups & 2.374 & 6 & .396 & .435 & .855 \\
\hline & Within Groups & 154.587 & 170 & .909 & & \\
\hline & Total & 156.960 & 176 & & & \\
\hline \multirow{3}{*}{ 24. Learning to use Web 2.0 technologies is easy for me } & Between Groups & 4.527 & 6 & .755 & .924 & .479 \\
\hline & Within Groups & 138.840 & 170 & .817 & & \\
\hline & Total & 143.367 & 176 & & & \\
\hline \multirow{3}{*}{$\begin{array}{l}\text { 25. Learning to use Web } 2.0 \text { technologies is beneficial to me as a faculty member in } \\
\text { higher education }\end{array}$} & Between Groups & 5.646 & 6 & .941 & 1.212 & .303 \\
\hline & Within Groups & 132.015 & 170 & .777 & & \\
\hline & Total & 137.661 & 176 & & & \\
\hline \multirow{3}{*}{ 26. My students expect me to use Web 2.0 technology for instruction } & Between Groups & 4.631 & 6 & .772 & .791 & .578 \\
\hline & Within Groups & 165.922 & 170 & .976 & & \\
\hline & Total & 170.554 & 176 & & & \\
\hline \multirow{3}{*}{ 28. Infusing Web 2.0 technologies within my course content is a requirement for me } & Between Groups & 6.001 & 6 & 1.000 & .828 & .550 \\
\hline & Within Groups & 205.333 & 170 & 1.208 & & \\
\hline & Total & 211.333 & 176 & & & \\
\hline \multirow{3}{*}{ 33. I find it difficult to find the time to attend faculty development programs } & Between Groups & 11.977 & 6 & 1.996 & 2.231 & .042 \\
\hline & Within Groups & 152.102 & 170 & .895 & & \\
\hline & Total & 164.079 & 176 & & & \\
\hline \multirow{3}{*}{ 34. I find it difficult to keep up with technology because it is constantly changing } & Between Groups & 6.446 & 6 & 1.074 & .946 & .463 \\
\hline & Within Groups & 192.989 & 170 & 1.135 & & \\
\hline & Total & 199.435 & 176 & & & \\
\hline \multirow{3}{*}{ 35. There is adequate computer access in most classrooms I teach in } & Between Groups & 6.773 & 6 & 1.129 & .887 & .506 \\
\hline & Within Groups & 216.289 & 170 & 1.272 & & \\
\hline & Total & 223.062 & 176 & & & \\
\hline \multirow{3}{*}{ 36. Students are far more advanced in technology than I am } & Between Groups & 3.087 & 6 & .514 & .399 & .879 \\
\hline & Within Groups & 218.958 & 170 & 1.288 & & \\
\hline & Total & 222.045 & 176 & & & \\
\hline \multirow{3}{*}{ 37. It takes me a long time to learn how to use Web 2.0 technologies } & Between Groups & 10.932 & 6 & 1.822 & 1.750 & .112 \\
\hline & Within Groups & 176.977 & 170 & 1.041 & & \\
\hline & Total & 187.910 & 176 & & & \\
\hline \multirow{3}{*}{$\begin{array}{l}\text { 38. There are many incentives or reward programs available to faculty who attend } \\
\text { faculty development programs on campus }\end{array}$} & Between Groups & 3.936 & 6 & .656 & .591 & .737 \\
\hline & Within Groups & 188.775 & 170 & 1.110 & & \\
\hline & Total & 192.712 & 176 & & & \\
\hline \multirow{3}{*}{ 40. I am self-motivated } & Between Groups & 2.825 & 6 & .471 & .641 & .698 \\
\hline & Within Groups & 124.916 & 170 & .735 & & \\
\hline & Total & 127.740 & 176 & & & \\
\hline
\end{tabular}

ception based on employment status of the impact of the barriers affecting technology integration and the faculty members' ability to utilize Web 2.0 technologies. Therefore, the null hypothesis is accepted. There is no relationship between faculty members' perception of the impact of the barriers affecting technology integration and the faculty members' ability to utilize Web 2.0 technologies.

The fifth research question was:

Is there a difference in male and female faculty members' perceptions regarding their use of Web 2.0 technologies in their 
courses?

The supporting hypothesis statements for the fifth research question were:

$\mathrm{H} 5_{0}=$ There is no relationship between faculty members' gender and perception regarding their use of Web 2.0 technologies in their courses.

$\mathrm{H} 5_{1}=$ There is a relationship between faculty members' gender and perception regarding their use of Web 2.0 technologies in their courses.

The survey questions related to this research question were the following:

- Survey Question 1: Please select your gender.

- Survey Question 22: Using Web 2.0 technologies improves the quality of my teaching.

- Survey Question 23: Using Web 2.0 technologies enhances the student's experiences in the classroom.

- Survey Question 25: Learning to use Web 2.0 technologies is beneficial to me as a faculty member in higher education.

- Survey Question 26: My students expect me to use Web 2.0 technology for instruction.

- Survey Question 27: There are no differences in what I taught utilizing Web 2.0 technologies versus the traditional classroom method.

- Survey Question 39: Teaching courses utilizing Web 2.0 technologies provides more flexibility than with the traditional face-to-face method.

- Survey Question 40: I am self-motivated.

A One Way ANOVA of survey questions relating to perception regarding their use of Web 2.0 technologies in their courses based on gender was conducted. The results can be seen in Table 53.

As Table 53 indicates, the $p$-values (Sig.) are .002, .000, .073, $.000, .118, .012$, and .117 respectively. When the $p$-value is less than the commonly accepted .05 value, we reject the null hypothesis. In this case all of the $p$-values are less than .05 except for three. That said, the null hypothesis is rejected. There was a significant difference between faculty members' gender and perception regarding their use of Web 2.0 technologies in their courses. Therefore, the alternate hypothesis is accepted. There is a relationship between faculty members' gender and perception regarding their use of Web 2.0 technologies in their courses.

The sixth research question was:

Is there a difference in faculty members' perceptions regarding their use of Web 2.0 technologies in their courses respective to their age?

The supporting hypothesis statements for the sixth research question were:

$\mathrm{H6}_{0}=$ There is no relationship between faculty members' age and perception regarding their use of Web 2.0 technologies in their courses.

$\mathrm{H6}_{1}=$ There is a relationship between faculty members' age and perception regarding their use of Web 2.0 technologies in their courses.

The survey questions related to this research question were the following:

- Survey Question 2: Which category below includes your age.

- Survey Question 22: Using Web 2.0 technologies improves the quality of my teaching.

- Survey Question 23: Using Web 2.0 technologies enhances the student's experiences in the classroom.

- Survey Question 25: Learning to use Web 2.0 technologies is beneficial to me as a faculty member in higher education.

- Survey Question 26: My students expect me to use Web 2.0 technology for instruction.

Table 53.

One way ANOVA test based on gender.

\begin{tabular}{|c|c|c|c|c|c|c|}
\hline & & Sum of Squares & df & Mean Square & $\mathrm{F}$ & Sig. \\
\hline \multirow{3}{*}{ 22. Using Web 2.0 technologies improves the quality of my teaching } & Between Groups & 7.141 & 1 & 7.141 & 10.267 & .002 \\
\hline & Within Groups & 121.718 & 175 & .696 & & \\
\hline & Total & 128.859 & 176 & & & \\
\hline \multirow{3}{*}{ 23. Using Web 2.0 technologies enhances the student's experiences in the classroom } & Between Groups & 10.831 & 1 & 10.831 & 16.424 & .000 \\
\hline & Within Groups & 115.406 & 175 & .659 & & \\
\hline & Total & 126.237 & 176 & & & \\
\hline \multirow{3}{*}{ 26. My students expect me to use Web 2.0 technology for instruction } & Between Groups & 3.104 & 1 & 3.104 & 3.244 & .073 \\
\hline & Within Groups & 167.449 & 175 & .957 & & \\
\hline & Total & 170.554 & 176 & & & \\
\hline \multirow{3}{*}{$\begin{array}{l}\text { 25. Learning to use Web } 2.0 \text { technologies is beneficial to me as a faculty member in } \\
\text { higher education }\end{array}$} & Between Groups & 13.616 & 1 & 13.616 & 19.209 & .000 \\
\hline & Within Groups & 124.045 & 175 & .709 & & \\
\hline & Total & 137.661 & 176 & & & \\
\hline \multirow{3}{*}{$\begin{array}{l}\text { 27. There are no differences in what I taught utilizing Web } 2.0 \text { technologies versus } \\
\text { the traditional classroom method }\end{array}$} & Between Groups & 2.587 & 1 & 2.587 & 2.464 & .118 \\
\hline & Within Groups & 183.718 & 175 & 1.050 & & \\
\hline & Total & 186.305 & 176 & & & \\
\hline \multirow{3}{*}{$\begin{array}{l}\text { 39. Teaching courses utilizing Web } 2.0 \text { technologies provides more flexibility than } \\
\text { with the traditional face-to-face method }\end{array}$} & Between Groups & 5.889 & 1 & 5.889 & 6.438 & .012 \\
\hline & Within Groups & 160.088 & 175 & .915 & & \\
\hline & Total & 165.977 & 176 & & & \\
\hline \multirow{3}{*}{ 40. I am self-motivated } & Between Groups & 1.782 & 1 & 1.782 & 2.476 & .117 \\
\hline & Within Groups & 125.958 & 175 & .720 & & \\
\hline & Total & 127.740 & 176 & & & \\
\hline
\end{tabular}


- Survey Question 27: There are no differences in what I taught utilizing Web 2.0 technologies versus the traditional classroom method.

- Survey Question 39: Teaching courses utilizing Web 2.0 technologies provides more flexibility than with the traditional face-to-face method.

- Survey Question 40: I am self-motivated.

A One Way ANOVA of survey questions relating to perception regarding their use of Web 2.0 technologies in their courses based on age was conducted. The results can be seen in Table 54.

As Table 54 indicates, the $p$-values (Sig.) are .001, .008, .111, $.027, .026, .100$, and .010 respectively. When the $p$-value is less than the commonly accepted .05 value, we reject the null hypothesis. In this case all of the $p$-values are less than .05 except for two. That said, the null hypothesis is rejected. There was a significant difference between faculty members' age and perception regarding their use of Web 2.0 technologies in their courses. Therefore, the alternate hypothesis is accepted. There is a relationship between faculty members' age and perception regarding their use of Web 2.0 technologies in their courses. A Bonferroni multiple comparison test was conducted on age to see which pairs were significantly different. The results of the test can be seen in Table $\mathbf{5 5}$.

Table 55 revealed that there are a few pairs of means that are significantly different from each other.

Faculty members who were in the age range of $30-39$ believed that using Web 2.0 technologies improves the quality of their teaching significantly more than those faculty members who were in the age range of $50-59$ and $60-69$. Those faculty members who were in the age range of $30-39$ believed that using Web 2.0 technologies enhances the student's experiences in the classroom significantly more than the faculty members who were in the age range of $50-59$. The faculty members who were in the age range of $30-39$ believed that learning to use Web 2.0 technologies is beneficial to them as a faculty member in higher education significantly more than those faculty members who were in the age range of $60-69$. Faculty members who were in the age range of 20 - 29 believed that there are no differences in what they taught utilizing Web 2.0 technologies versus the traditional classroom method significantly more than the faculty member who were in the age ranges of $60-69$ and $70+$. Faculty members who were in the age range of $60-69$ believe that they are self-motivated significantly more than the faculty members who were in the age range of $20-29$.

The seventh research question was:

Is there a difference in faculty members' perceptions regarding their use of Web 2.0 technologies in their courses respective to their employment status?

The supporting hypothesis statements for the seventh research question were:

$\mathrm{H} 7_{0}=$ There is no relationship between faculty members' status and perception regarding their use of Web 2.0 technologies in their courses.

$\mathrm{H} 7_{1}=$ There is a relationship between faculty members' status and perception regarding their use of Web 2.0 technologies in their courses.

The survey questions related to this research question were the following:

- Survey Question 3: Please select the number of years you have been teaching in higher education.

- Survey Question 4: Please select the number of years you have been teaching at your University.

- Survey Question 5: Please select your current employment status within the University.

- Survey Question 22: Using Web 2.0 technologies improves the quality of my teaching.

- Survey Question 23: Using Web 2.0 technologies enhances the student's experiences in the classroom.

- Survey Question 25: Learning to use Web 2.0 technologies is beneficial to me as a faculty member in higher education.

- Survey Question 26: My students expect me to use Web 2.0 technology for instruction.

- Survey Question 27: There are no differences in what I taught utilizing Web 2.0 technologies versus the traditional classroom method.

Table 54.

One way ANOVA test based on age.

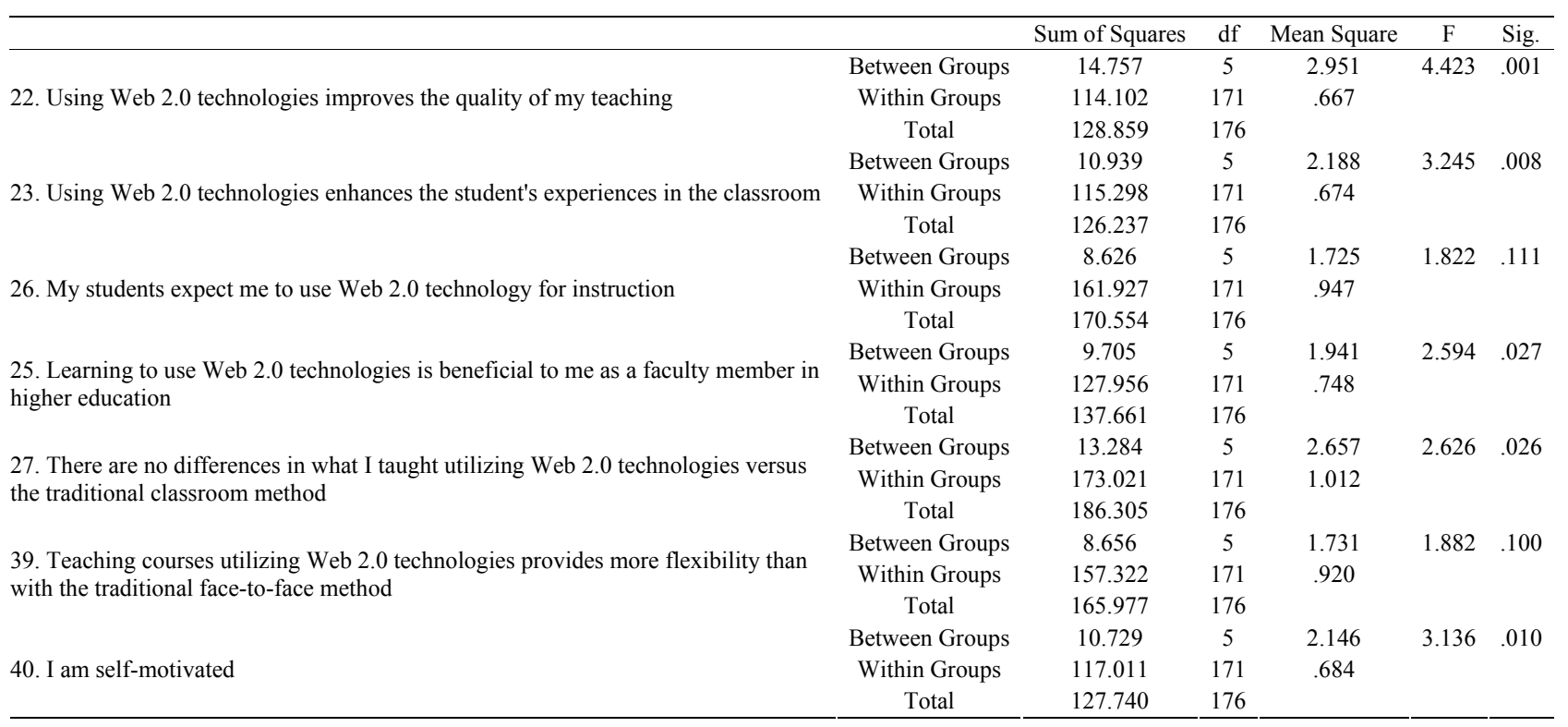




\section{S. A. ZELICK}

Table 55.

Bonferroni multiple comparison on age.

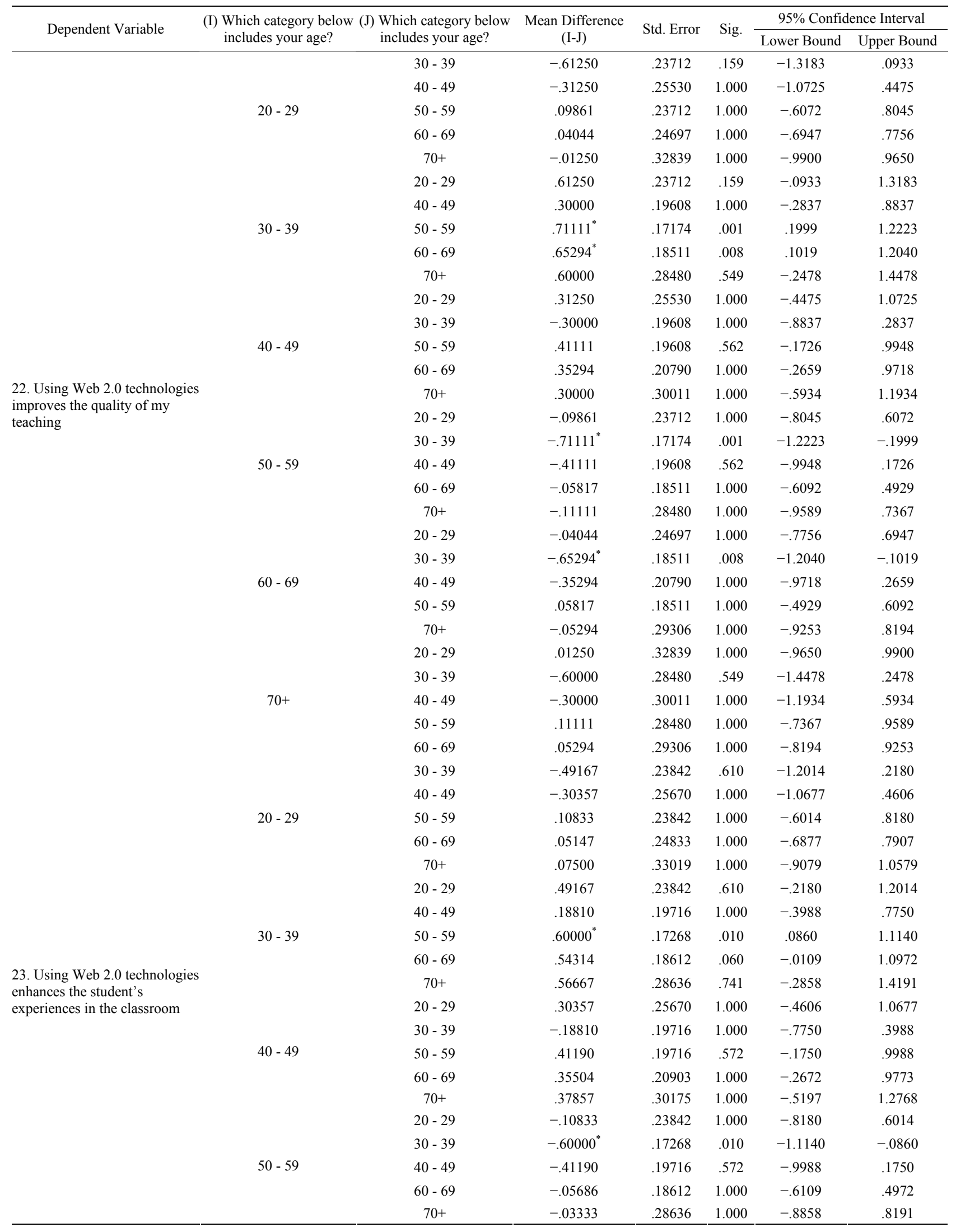




\section{S. A. ZELICK}

Continued

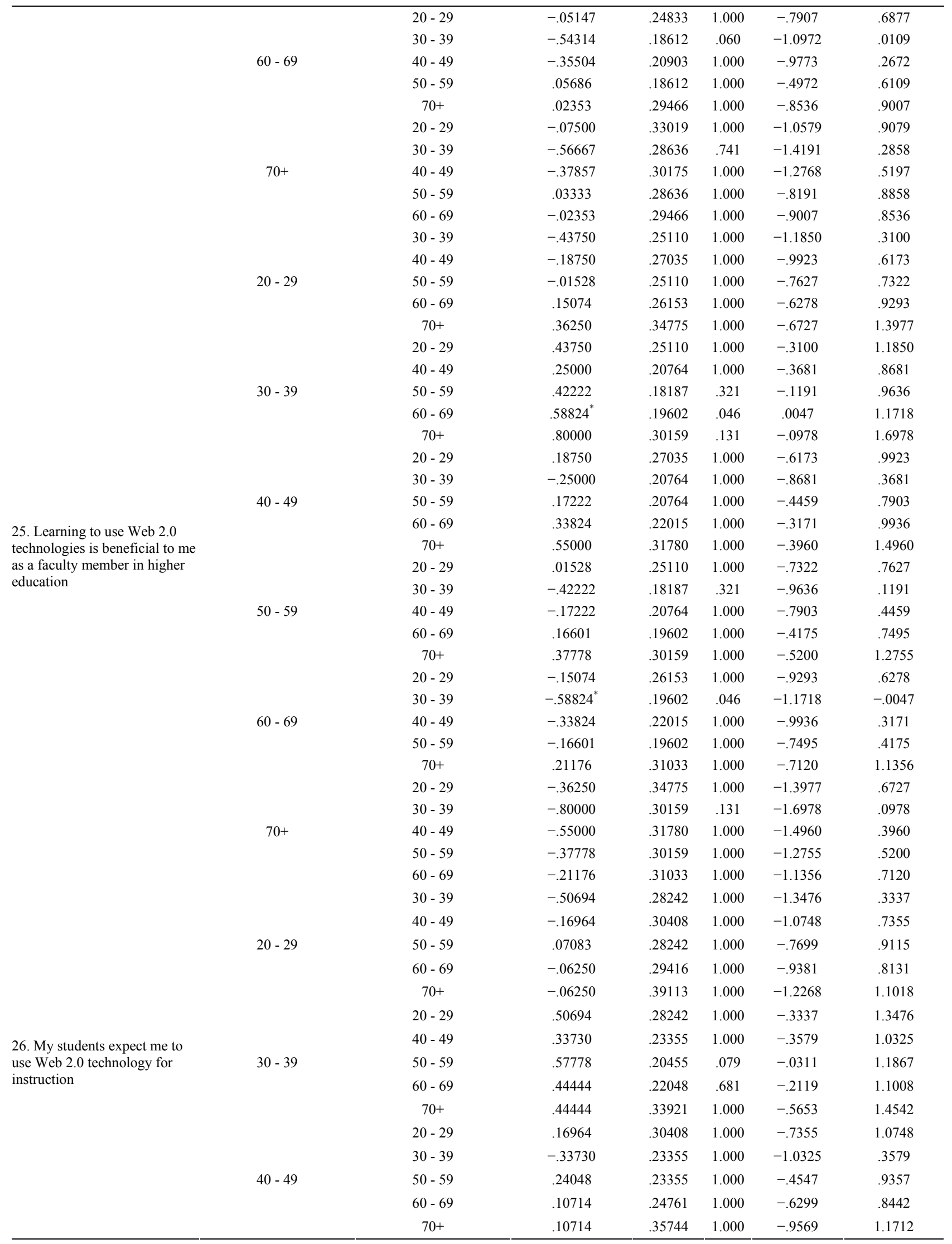




\section{S. A. ZELICK}

Continued

27. There are no differences in what I taught utilizing Web 2.0 technologies versus the

traditional classroom method

40. I am self-motivated

$$
50-59
$$$$
20-29
$$

30 - 39

$60-69$

$20-29$

$40-49$

$30-39$

$50-59$

$60-69$

$70+$

$$
20-29
$$

$$
\begin{gathered}
40-49 \\
60-69 \\
70+
\end{gathered}
$$$$
20-29
$$$$
30-39
$$$$
40 \text { - } 49
$$$$
50-59
$$$$
70+
$$$$
20 \text { - } 29
$$$$
30 \text { - } 39
$$$$
40 \text { - } 49
$$$$
50-59
$$$$
60-69
$$$$
30-39
$$$$
40-49
$$

$50-59$

$60-69$

$70+$

$20-29$

$40-49$

$50-59$

$60-69$

$70+$

20 - 29

30 - 39

$50-59$

$60-69$

$70+$

20 - 29

$30-39$

$40-49$

$60-69$

$70+$

20 - 29

30 - 39

40 - 49

50 - 59

$70+$

20 - 29

30 - 39

40 - 49

$50-59$

$60-69$

$30-39$

$40-49$

$50-59$

$60-69$

$70+$

20 - 29

40 - 49

$30-39$
$50-59$

$60-69$

$70+$

$-.07083$

.07083
-.57778

$-.24048$

$-.13333$

$-.13333$

.06250

$-.44444$

$-.10714$

.13333

.00000

.06250

$-.44444$

$-.10714$

.13333

.00000

.70417

.68750

.74861

$.93750^{*}$

$1.32639^{*}$

$-.70417$

$-.01667$

.04444

.23333

.62222

$-.68750$

.01667

.06111

.25000

.63889

$-.74861$

$-.04444$

$-.06111$

.18889

.57778

.57778
$-.93750^{*}$

$-.23333$

$-.25000$

$-.18889$

.38889

$-1.32639^{*}$

$-.62222$

$-.63889$

$-.57778$

$-.38889$

$-.50000$

$-.64286$

$-.63333$

$-.94118^{*}$

$-.83333$

.50000

$-.14286$

$-.13333$

$-.44118$

$-.33333$

.28242

.28242
.20455

.23355

.22048

.33921

.29416

.22048

.24761

.22048

.34905

.39113

.33921

.35744

.33921

.34905

.34905
.29279

$.29279 \quad .259$

$.31524 \quad .458$

$.29279 \quad .171$

$.30496 \quad .037$

$.41912 \quad .028$

$.29279 \quad .259$

$.24212 \quad 1.000$

$.21206 \quad 1.000$

$.22857 \quad 1.000$

$.36730 \quad 1.000$

$.31524 \quad .458$

$.24212 \quad 1.000$

$.24212 \quad 1.000$

$.25670 \quad 1.000$

$.38544 \quad 1.000$

$\begin{array}{rr}.38544 & 1.000 \\ 29279 & 171\end{array}$

$.21206 \quad 1.000$

$.24212 \quad 1.000$

$.22857 \quad 1.000$

$.36730 \quad 1.000$

.30496

.22857

.25670

.22857

37707

$37707 \quad 1.000$

$.41912 \quad .028$

$.36730 \quad 1.000$

$\begin{array}{ll}.38544 & 1.000\end{array}$

$\begin{array}{ll}.36730 & 1.000\end{array}$

$37707 \quad 1.000$

.37707

.24078

$24078 \quad .590$

$.25924 \quad .212$

$.24078 \quad .140$

$.25078 \quad .004$

$.34467 \quad .250$

$.24078 \quad .590$

$.19911 \quad 1.000$

$.17439 \quad 1.000$

$.18797 \quad .301$

$.30205 \quad 1.000$
$-9115$

$-1.1867$

$-.9357$

$-.7896$

$-1.1431$

-1.1431
-.8131

$-1.1008$

$-.8442$

$-.5230$

$-1.0390$

$-1.1018$

$-1.4542$

$-1.1712$

$-.8764$

$-1.0390$

$-.1675$

-.1675
-.2510

$-.1230$

.0296

.0787

$-1.5758$

$-.7375$

-.5869
-.4471

$-.4471$

$-.4712$

$-1.6260$

$-.7041$

$-.6597$

$-.5142$

$-.5086$

$-1.6202$

$-.6757$

$-.7819$

$-.4916$

$-.5157$

$-1.8454$

$-.9138$

$-1.0142$

$-.8693$

$-.7337$

-.7337
-2.5741

$-1.7157$

$-1.7863$

$-1.6712$

$-1.5114$

$-1.2168$

$-1.4146$

$-1.3501$

$-1.6878$

$-1.8594$

$-.2168$

$-.7356$

$-.6525$

$-1.0008$

$-1.2325$

.7699

.0311

.4547

.5230

.8764

.9381

.2119

.6299

.7896

1.0390

1.2268

.5653

.9569

1.1431

1.0390

1.5758

1.6260

1.6202

1.8454

2.5741

.1675

.7041

.6757

.9138

1.7157

.2510

.7375

.7819

1.0142

1.7863

.1230 


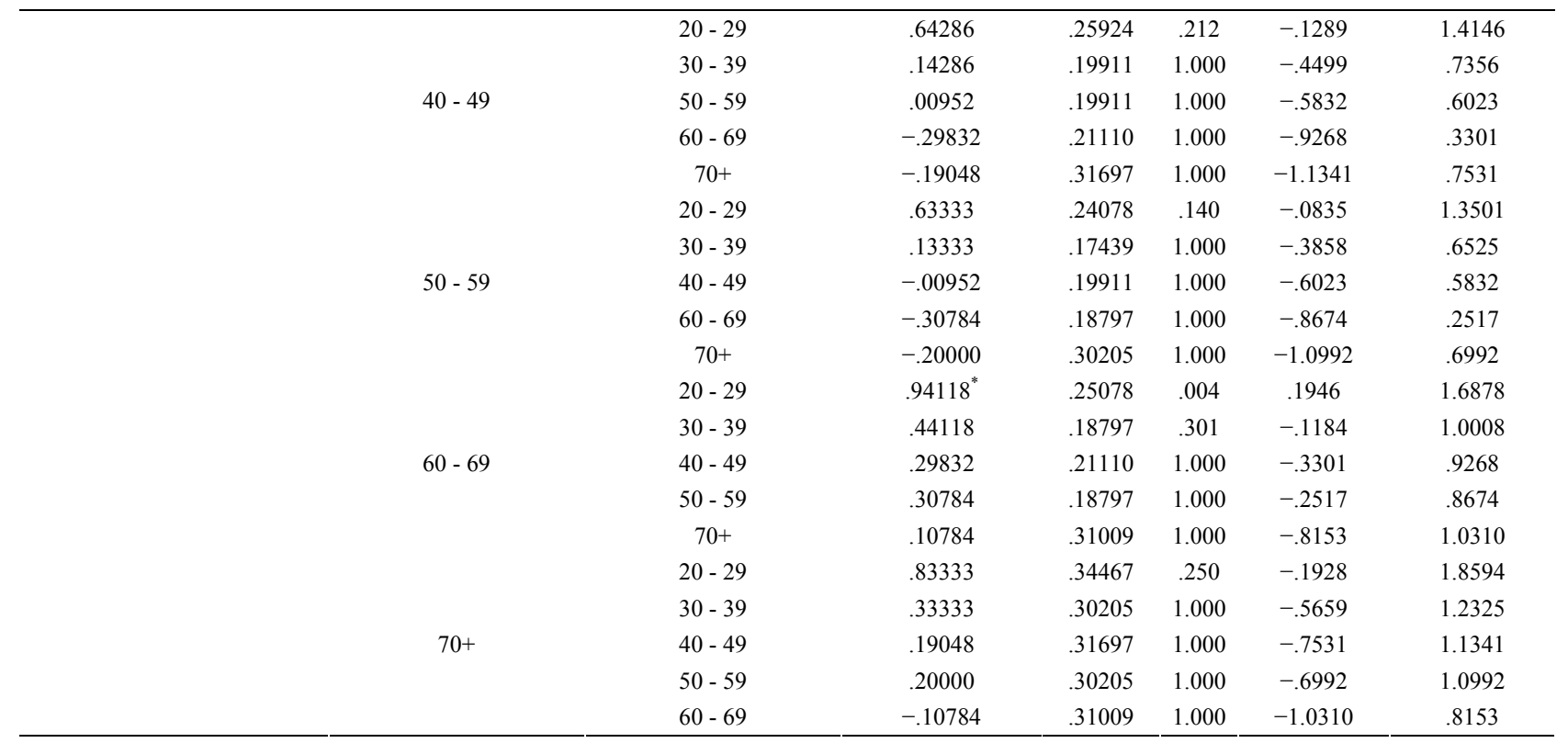

Note. ${ }^{*}$ The mean difference is significant at the .05 level.

- Survey Question 40: I am self-motivated.

A One Way ANOVA of survey questions relating to perception regarding their use of Web 2.0 technologies in their courses based on number of years teaching in higher education was conducted. The results can be seen in Table 56 .

As Table 56 indicates, the $p$-values (Sig.) are .013, .004, .037, $.531, .659$, and .549 respectively. When the $p$-value is less than the commonly accepted .05 value, we reject the null hypothesis. In this case all of the $p$-values are greater than .05 . That said, the null hypothesis is not rejected. There was no significant difference between faculty members' number of years teaching in higher education and perception regarding their use of Web 2.0 technologies in their courses. Therefore, the null hypothesis is accepted. There is no relationship between faculty members' status and perception regarding their use of Web 2.0 technologies in their courses.

An additional One Way ANOVA of survey questions relating to perception regarding their use of Web 2.0 technologies in their courses based on number of years teaching at their university was conducted. The results can be seen in Table 57.

As Table 57 indicates, the $p$-values (Sig.) are .231, .304, .397, $.982, .838$, and .077 respectively. When the $p$-value is less than the commonly accepted .05 value, the null hypothesis is rejected. In this case all of the $p$-values are greater than .05. That said, we do not reject the null hypothesis. There was no significant difference between faculty members' number of years teaching at their university and perception regarding their use of Web 2.0 technologies in their courses. Therefore, the null hypothesis is accepted. There is no relationship between faculty members' status and perception regarding their use of Web 2.0 technologies in their courses.

A third One Way ANOVA of survey questions relating to perception regarding their use of Web 2.0 technologies in their courses based on employment status was conducted. The results can be seen in Table 58 .

As Table 58 indicates, the $p$-values (Sig.) are .101, .879, .578, $.303, .407, .681$, and .698 respectively. When the $p$-value is less than the commonly accepted .05 value, we reject the null hypothesis. In this case all of the $p$-values are greater than .05 . That said, the null hypothesis is not rejected. There was no significant difference between faculty members' employment status and perception regarding their use of Web 2.0 technologies in their courses. Therefore, the null hypothesis is accepted. There is no relationship between faculty members' status and perception regarding their use of Web 2.0 technologies in their courses.

A Bonferroni multiple comparison test was conducted on number of years teaching in higher education to see which pairs were significantly different. The test can be seen in Table 59.

Table 59 revealed that there are a few pairs of means that are significantly different from each other. Faculty members who have been teaching in higher education for 1 - 5 years believed that using Web 2.0 technologies improves the quality of their teaching significantly more than those faculty members who have been teaching in higher education for $21+$ years. Those faculty members who worked in higher education for $1-5$ years believed that using Web 2.0 technologies enhances the student's experiences in the classroom significantly more than the faculty members who have taught in higher education for 11 - 15 years and those faculty members who have taught in higher education $21+$ years. The faculty members who have taught in higher education for 6 - 10 years believed that learning to use Web 2.0 technologies is beneficial to them as a faculty member in higher education significantly more than those faculty members who have taught in higher education for $21+$ years.

\section{Summary}

The purpose of this study was to examine faculty members' perception of Web 2.0 technologies on teaching and learning in higher education compared to traditional classroom teaching methods in programs at a higher education institutions to establish if relationships prevail in their delivery of courses through the use of Web 2.0 technologies compared with traditional 
Table 56.

One way ANOVA test based on years teaching in higher education.

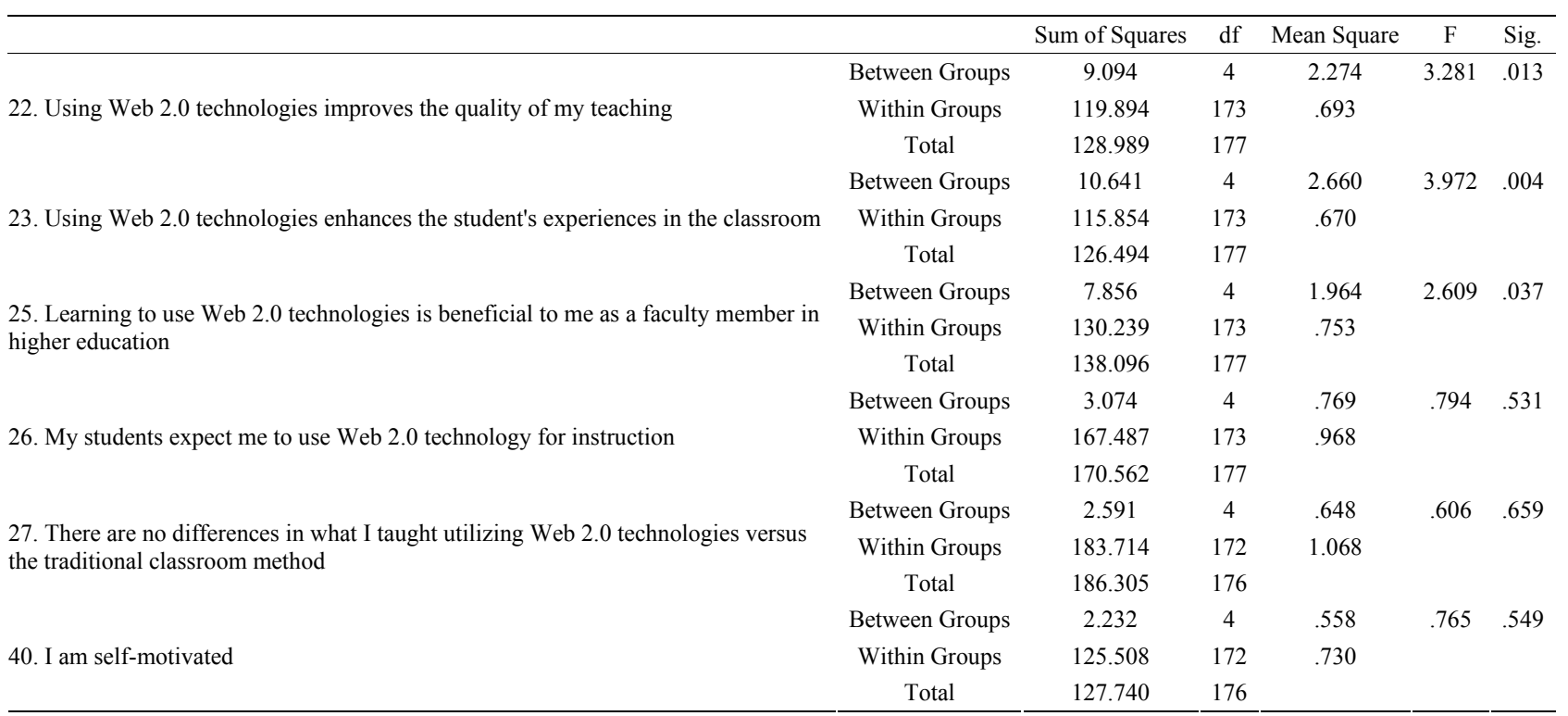

Table 57.

One way ANOVA test based on years teaching at your university.

\begin{tabular}{|c|c|c|c|c|c|c|}
\hline & & Sum of Squares & $\mathrm{df}$ & Mean Square & $\mathrm{F}$ & Sig. \\
\hline \multirow{3}{*}{ 22. Using Web 2.0 technologies improves the quality of my teaching } & Between Groups & 4.084 & 4 & 1.021 & 1.414 & .231 \\
\hline & Within Groups & 124.905 & 173 & .722 & & \\
\hline & Total & 128.989 & 177 & & & \\
\hline \multirow{3}{*}{ 23. Using Web 2.0 technologies enhances the student's experiences in the classroom } & Between Groups & 3.472 & 4 & .868 & 1.221 & .304 \\
\hline & Within Groups & 123.022 & 173 & .711 & & \\
\hline & Total & 126.494 & 177 & & & \\
\hline \multirow{3}{*}{$\begin{array}{l}\text { 25. Learning to use Web } 2.0 \text { technologies is beneficial to me as a faculty member in } \\
\text { higher education }\end{array}$} & Between Groups & 3.189 & 4 & .797 & 1.022 & .397 \\
\hline & Within Groups & 134.907 & 173 & .780 & & \\
\hline & Total & 138.096 & 177 & & & \\
\hline \multirow{3}{*}{ 26. My students expect me to use Web 2.0 technology for instruction } & Between Groups & .398 & 4 & .099 & .101 & 982 \\
\hline & Within Groups & 170.164 & 173 & 984 & & \\
\hline & Total & 170.562 & 177 & & & \\
\hline \multirow{3}{*}{$\begin{array}{l}\text { 27. There are no differences in what I taught utilizing Web } 2.0 \text { technologies versus } \\
\text { the traditional classroom method }\end{array}$} & Between Groups & 1.541 & 4 & .385 & .359 & .838 \\
\hline & Within Groups & 184.764 & 172 & 1.074 & & \\
\hline & Total & 186.305 & 176 & & & \\
\hline \multirow{3}{*}{ 40. I am self-motivated } & Between Groups & 6.078 & 4 & 1.519 & 2.148 & .077 \\
\hline & Within Groups & 121.662 & 172 & .707 & & \\
\hline & Total & 127.740 & 176 & & & \\
\hline
\end{tabular}

classroom delivery of courses; their overall satisfaction; the level of faculty development programs available; and their perceived effectiveness and impact of faculty development and issues and barriers affecting technology integration. This study also examined the influence of gender, age, and employment status on faculty members' perceptions of Web 2.0 technologies on teaching and learning in higher education compared to traditional classroom teaching methods.

With technology continuing to expand at a rapid rate and being ever changing (Rockart, Earl, \& Ross, 1996), trying to constantly be on the cutting edge of technology in higher education is an interesting paradigm. "In some schools, the Internet and other technologies are being integrated at the institutional level; with a student's complete academic experience-from applica- tion through registration and tuition payment, to final examination and course grade-occurring on-line" (Gottwald, 2005: p. 2). The rapidly growing technology infrastructure at institutions of higher education to meet the instructional and research needs of faculty, staff, and students (Alsaady, 2007) is making faculty development with the use of technology a requirement. Between 2002 and 2006, online learning increased by $21.5 \%$ while the entire higher education student body only increased by $1.5 \%$ (Yates, 2010).

This study investigated faculty members' perception of Web 2.0 technologies on teaching and learning in higher education compared to traditional classroom teaching methods. The study will also examine the effects of gender and age variables on their adoption of technological approaches to teaching. The 
Table 58.

One way ANOVA test based on employment status.

\begin{tabular}{|c|c|c|c|c|c|c|}
\hline & & Sum of Squares & df & Mean Square & $\mathrm{F}$ & Sig. \\
\hline \multirow{3}{*}{ 22. Using Web 2.0 technologies improves the quality of my teaching } & Between Groups & 7.705 & 6 & 1.284 & 1.802 & .101 \\
\hline & Within Groups & 121.154 & 170 & .713 & & \\
\hline & Total & 128.859 & 176 & & & \\
\hline \multirow{3}{*}{ 23. Using Web 2.0 technologies enhances the student's experiences in the classroom } & Between Groups & 1.755 & 6 & .292 & .399 & .879 \\
\hline & Within Groups & 124.483 & 170 & .732 & & \\
\hline & Total & 126.237 & 176 & & & \\
\hline \multirow{3}{*}{ 25. My students expect me to use Web 2.0 technology for instruction } & Between Groups & 4.631 & 6 & .772 & .791 & .578 \\
\hline & Within Groups & 165.922 & 170 & .976 & & \\
\hline & Total & 170.554 & 176 & & & \\
\hline \multirow{3}{*}{$\begin{array}{l}\text { 26. Learning to use Web } 2.0 \text { technologies is beneficial to me as a faculty member in } \\
\text { higher education }\end{array}$} & Between Groups & 5.646 & 6 & .941 & 1.212 & .303 \\
\hline & Within Groups & 132.015 & 170 & .777 & & \\
\hline & Total & 137.661 & 176 & & & \\
\hline \multirow{3}{*}{$\begin{array}{l}\text { 27. There are no differences in what I taught utilizing Web } 2.0 \text { technologies versus } \\
\text { the traditional classroom method }\end{array}$} & Between Groups & 6.541 & 6 & 1.090 & 1.031 & 407 \\
\hline & Within Groups & 179.764 & 170 & 1.057 & & \\
\hline & Total & 186.305 & 176 & & & \\
\hline \multirow{3}{*}{ 40. I am self-motivated } & Between Groups & 2.825 & 6 & .471 & .641 & .698 \\
\hline & Within Groups & 124.916 & 170 & .735 & & \\
\hline & Total & 127.740 & 176 & & & \\
\hline
\end{tabular}

problem with advanced technological utilization by faculty in higher education is that higher education institutions are installing state of the art technology into classrooms and faculty members are expected to infuse this technology into their teaching, but only about $20 \%$ of faculty members feel that they are prepared to comply (Chuang, 2004). Internet usage among 18 - 29 years old college student is at a staggering $93 \%$ and " $44 \%$ of the nearly 53 million Internet users produce and share digital content online" (Weyant \& Gardner, 2010, p. 68). Not only are these students ahead of the faculty when it comes to technical skills and utilization, but the corporations that are waiting for these students to graduate are expecting familiarity of Web 2.0 technologies (Weyant \& Gardner, 2010).

With technology continuing to expand at a rapid rate and being ever changing (Rockart et al., 1996), just keeping up with it can be a daunting task in itself. "In some schools, the Internet and other technologies are being integrated at the institutional level; with a student's complete academic experience-from application through registration and tuition payment, to final examination and course grade-occurring on-line" (Gottwald, 2005: p. 2). The rapidly growing technology infrastructure at institutions of higher education to meet the instructional and research needs of faculty, staff, and students (Alsaady, 2007) is making faculty development with the use of technology a requirement. Between 2002 and 2006, online learning increased by $21.5 \%$ while the entire higher education student body only increased by $1.5 \%$ (Yates, 2010). These are pretty alarming statistics and with Web 3.0 moving fast upon us, institutions of higher education need to put improving teaching and learning through the use of Web 2.0 technologies as a priority in their strategic plans so faculty members can learn not only how to use Web 2.0 technologies, but how to successfully infuse Web 2.0 technologies into their curriculums to improve learning.

In order for faculty members' to remain competitive and sustainable in this digital age, professional development on the use of technology and how to infuse technology into course curricula is a requirement. Identifying the aspects of effectiveness and potential impacts of faculty development will recog- nize areas of success and failure and will contribute to improving the content of faculty development (Al-Washahi, 2007). The results are expected to empower the faculty members to actively infuse technology into their curriculum and classroom, thus providing a state of the art experience for the student community at institutions of higher education.

\section{Discussion of Findings}

Of 177 faculty members who participated in this research study, the majority were male adjunct faculty members in the age range of either $30-39$ or $50-59$ who has been teaching in higher education for either 1 - 5 years or $21+$ years and had been teaching at their university for $1-5$ years. In addition, the majority taught undergraduate course utilizing the traditional face-to-face teaching method and more surprisingly, traditional face-to-face teaching method was the preferred teaching method. When asked to rate their technical proficiency level, the majority of the respondents felt they were either somewhat proficient or proficient; and when the respondents were asked to rate their technical proficiency level specifically to the Web 2.0 technologies that their University offers, the majority felt they were somewhat proficient. Lastly, the majority of the respondents learn best by doing.

Based on the results from the current level of Web 2.0 technologies use at their university, adjunct faculty members were the most to have never utilized all of the Web 2.0 technologies except for YouTube where the adjunct faculty members sometimes utilized that technology; professors often utilized Blog, Skype and Twitter; assistant professors often utilized YouTube and very often utilized Podcast.

Sixty-five or $36.7 \%$ of the faculty members agreed that using Web 2.0 technologies improves the quality of teaching and 81 or $45.8 \%$ of the faculty members agreed that using Web 2.0 technologies enhances student's experiences. Close to $40 \%$ of the participants remained neutral regarding the level of ease to learn to use Web 2.0 technologies. Almost half of the faculty members $(46.9 \%)$ agreed that learning to use Web 2.0 tech- 


\section{S. A. ZELICK}

Table 59.

Bonferroni multiple comparisons for years teaching in higher education.

\begin{tabular}{|c|c|c|c|c|c|c|c|}
\hline \multirow{2}{*}{ Dependent Variable } & \multirow{2}{*}{$\begin{array}{l}\text { (I) Please select the number } \\
\text { of years you have been } \\
\text { teaching in higher education }\end{array}$} & \multirow{2}{*}{$\begin{array}{l}\text { (J) Please select the number } \\
\text { of years you have been } \\
\text { teaching in higher education }\end{array}$} & \multirow{2}{*}{$\begin{array}{l}\text { Mean Difference } \\
\text { (I-J) }\end{array}$} & \multirow{2}{*}{ Std. Error } & \multirow{2}{*}{ Sig. } & \multicolumn{2}{|c|}{$95 \%$ Confidence Interval } \\
\hline & & & & & & Lower Bound & Upper Bound \\
\hline \multirow{19}{*}{$\begin{array}{l}\text { 22. Using Web } 2.0 \\
\text { technologies improves the } \\
\text { quality of my teaching }\end{array}$} & \multirow{4}{*}{$1-5$} & $6-10$ & .08238 & .18249 & 1.000 & -.4365 & .6013 \\
\hline & & $11-15$ & .32298 & .19954 & 1.000 & -.2444 & .8904 \\
\hline & & $16-20$ & .29051 & .21579 & 1.000 & -.3231 & .9041 \\
\hline & & $21+$ & $.58597^{*}$ & .17555 & .010 & .0868 & 1.0851 \\
\hline & \multirow{4}{*}{$6-10$} & $1-5$ & -.08238 & .18249 & 1.000 & -.6013 & .4365 \\
\hline & & $11-15$ & .24060 & .20734 & 1.000 & -.3490 & .8302 \\
\hline & & $16-20$ & .20813 & .22302 & 1.000 & -.4260 & .8423 \\
\hline & & $21+$ & .50359 & .18436 & .070 & -.0206 & 1.0278 \\
\hline & \multirow{4}{*}{$11-15$} & $1-5$ & -.32298 & .19954 & 1.000 & -.8904 & .2444 \\
\hline & & $6-10$ & -.24060 & .20734 & 1.000 & -.8302 & .3490 \\
\hline & & $16-20$ & -.03247 & .23718 & 1.000 & -.7069 & .6419 \\
\hline & & $21+$ & .26299 & .20125 & 1.000 & -.3093 & .8352 \\
\hline & \multirow{4}{*}{$16-20$} & $1-5$ & -.29051 & .21579 & 1.000 & -.9041 & .3231 \\
\hline & & $6-10$ & -.20813 & .22302 & 1.000 & -.8423 & .4260 \\
\hline & & $11-15$ & .03247 & .23718 & 1.000 & -.6419 & .7069 \\
\hline & & $21+$ & .29545 & .21738 & 1.000 & -.3226 & .9136 \\
\hline & \multirow{4}{*}{$21+$} & $1-5$ & $-.58597^{*}$ & .17555 & .010 & -1.0851 & -.0868 \\
\hline & & $6-10$ & -.50359 & .18436 & .070 & -1.0278 & .0206 \\
\hline & & $11-15$ & -.26299 & .20125 & 1.000 & -.8352 & .3093 \\
\hline \multirow{21}{*}{$\begin{array}{l}\text { 23. Using Web } 2.0 \\
\text { technologies enhances the } \\
\text { student's experiences in the } \\
\text { classroom }\end{array}$} & & $16-20$ & -.29545 & .21738 & 1.000 & -.9136 & .3226 \\
\hline & \multirow{4}{*}{$1-5$} & $6-10$ & .18192 & .17939 & 1.000 & -.3282 & .6920 \\
\hline & & $11-15$ & $.58230^{*}$ & .19615 & .034 & .0245 & 1.1400 \\
\hline & & $16-20$ & -.01186 & .21213 & 1.000 & -.6150 & .5913 \\
\hline & & $21+$ & $.51087^{*}$ & .17256 & .035 & .0202 & 1.0015 \\
\hline & \multirow{4}{*}{$6-10$} & $1-5$ & -.18192 & .17939 & 1.000 & -.6920 & .3282 \\
\hline & & $11-15$ & .40038 & .20381 & .511 & -.1792 & .9799 \\
\hline & & $16-20$ & -.19378 & .21923 & 1.000 & -.8172 & .4296 \\
\hline & & $21+$ & .32895 & .18123 & .712 & -.1864 & .8443 \\
\hline & \multirow{4}{*}{$11-15$} & $1-5$ & $-.58230^{*}$ & .19615 & .034 & -1.1400 & -.0245 \\
\hline & & $6-10$ & -.40038 & .20381 & .511 & -.9799 & .1792 \\
\hline & & $16-20$ & -.59416 & .23315 & .117 & -1.2571 & .0688 \\
\hline & & $21+$ & -.07143 & .19783 & 1.000 & -.6340 & .4911 \\
\hline & \multirow{4}{*}{$16-20$} & $1-5$ & .01186 & .21213 & 1.000 & -.5913 & .6150 \\
\hline & & $6-10$ & .19378 & .21923 & 1.000 & -.4296 & .8172 \\
\hline & & $11-15$ & .59416 & .23315 & .117 & -.0688 & 1.2571 \\
\hline & & $21+$ & .52273 & .21368 & .154 & -.0849 & 1.1303 \\
\hline & & $1-5$ & $-.51087^{*}$ & .17256 & .035 & -1.0015 & -.0202 \\
\hline & $21+$ & $6-10$ & -.32895 & .18123 & .712 & -.8443 & .1864 \\
\hline & 211 & $11-15$ & .07143 & .19783 & 1.000 & -.4911 & .6340 \\
\hline & & $16-20$ & -.52273 & .21368 & .154 & -1.1303 & .0849 \\
\hline & & $6-10$ & -.11670 & .19020 & 1.000 & -.6575 & .4241 \\
\hline & $1-5$ & $11-15$ & .26863 & .20797 & 1.000 & -.3227 & .8600 \\
\hline & $1-5$ & $16-20$ & .16798 & .22491 & 1.000 & -.4715 & .8075 \\
\hline & & $21+$ & .44071 & .18296 & .171 & -.0795 & .9610 \\
\hline 25. Learning to use Web 2.0 & & $1-5$ & .11670 & .19020 & 1.000 & -.4241 & .6575 \\
\hline technologies is beneficial to & $6-10$ & $11-15$ & .38534 & .21610 & .763 & -.2291 & .9998 \\
\hline me as a faculty member in & $0-10$ & $16-20$ & .28469 & .23245 & 1.000 & -.3763 & .9456 \\
\hline & & $21+$ & $.55742^{*}$ & .19215 & .042 & .0110 & 1.1038 \\
\hline & & $1-5$ & -.26863 & .20797 & 1.000 & -.8600 & .3227 \\
\hline & & $6-10$ & -.38534 & .21610 & .763 & -.9998 & .2291 \\
\hline & $11-15$ & $16-20$ & -.10065 & .24720 & 1.000 & -.8035 & .6023 \\
\hline & & $21+$ & .17208 & .20975 & 1.000 & -.4244 & .7685 \\
\hline
\end{tabular}




\section{S. A. ZELICK}

Continued

26. My students expect me to use Web 2.0 technology for instruction

27. There are no differences in what I taught utilizing Web 2.0 technologies versus the traditional

40. I am self-motivated

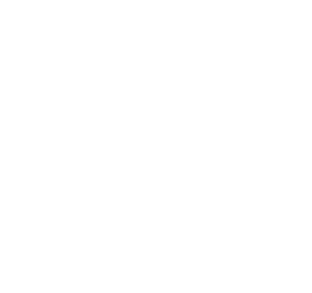

classroom method

$1-5$

$6-10$

$16-20$

$21+$

$11-15$

$16-20$

$21+$

$$
6-10
$$

$1-5$

$11-15$
$11-15$

$21+$

$1-5$

$6-10$

$11-15$

$16-20$

$6-10$

$11-15$

$16-20$

$21+$

$1-5$

$11-15$

$16-20$

$21+$

$1-5$

$6-10$

$16-20$

$21+$

$1-5$

$6-10$

$11-15$

$21+$

$1-5$

$6-10$

$11-15$

$16-20$

$6-10$

$11-15$

$16-20$

$21+$

$1-5$

$11-15$

$16-20$

$21+$

$1-5$

$6-10$

$16-20$

$21+$

$1-5$

$6-10$

$11-15$

$21+$

1 - 5

$6-10$

$11-15$

$16-20$

$6-10$

$11-15$

$16-20$

$21+$

1 - 5

$11-15$

$16-20$

$-.16798$

-.16798
-.28469

.10065

.27273

$-.44071$

$-.55742^{*}$

$-.17208$

$-.27273$

$-.20252$

$-.05590$

.04150

.17787

.20252

.14662

.24402

.38038

.05590

$-.14662$

.09740

.23377

$-.04150$

$-.24402$

$-.09740$

.13636

$-.17787$

$-.38038$

.38038
-.23377

$-.13636$

$-.22540$

.14010

$-.03162$

.05929

.22540

.36550

.19378

.28469

$-.14010$

$-.36550$

$-.17172$

$-.08081$

.03162

.03162
-.19378

.17172

.09091

$-.05929$

$-.28469$

.08081

$-.09091$

$-.01373$

.10225

$-.02569$

$-.23024$

.01373

.11598

$-.01196$

$-.21651$

.22491

.23245

.24720

.22656

.18296

.19215

.20975

.22656

.21569

.23584

.25505

.20748

.21569

.24506

.26360

.21790

.23584

.24506

.28033

.23786

.25505

.26360

.28033

.25692

.20748

.21790

.23786

.25692

.22656

.25056

.26790

.21793

.22656

.26013

.27687

.22887

.25056

.26013

.29683

.25266

.26790

.27687

.29683

.26986

.21793

.22887

.25266

.26986

.18726

.20710

.22143

.18013

.18726

.21501

.22885

.18917

1.000

$1.000-.8075$

$1.000 \quad-.9456$

$1.000-.6023$

$1.000 \quad-.3715$

$\begin{array}{ll}.171-.9610 \\ .042 & -1.1038\end{array}$

$.042 \quad-1.1038$

$\begin{array}{ll}.042 & -1.1038 \\ 1.000 & -.7685\end{array}$

$1.000 \quad-.9169$

$1.000 \quad-.8158$

$1.000 \quad-.7265$

$1.000 \quad-.6837$

$\begin{array}{ll}1.000 & -.6837 \\ 1.000 & -.4121\end{array}$

$1.000-.4108$

$1.000 \quad-.5502$

$1.000-.5055$

$\begin{array}{ll}.826-.2392 \\ 1.000 & -.6147\end{array}$

$\begin{array}{cc}.826 & -.2392 \\ 1.000 & -.6147\end{array}$

$1.000 \quad-.8434$

$1.000 \quad-.6997$

$1.000-.4426$

$1.000 \quad-.7667$

$\begin{array}{ll}1.000 & -.7667 \\ 1.000 & -.9936\end{array}$

$1.000 \quad-.8945$

$1.000 \quad-.5942$

$1.000 \quad-.7678$

$\begin{array}{cc}1.000 & -.7678 \\ 826 & -1.0000\end{array}$

$\begin{array}{ll}.826 & -1.0000 \\ 1.000 & -.9101\end{array}$

$1.000 \quad-.8669$

$1.000 \quad-.8697$

$\begin{array}{ll}1.000 & -.5724\end{array}$

$1.000 \quad-.7934$

$\begin{array}{ll}1.000 & -.7934 \\ 1.000 & -.5604\end{array}$

$1.000 \quad-.4189$

$1.000 \quad-.3742$

$1.000-.5936$

$1.000-.3662$

$\begin{array}{ll}1.000 & -.3662 \\ 1.000 & -.8526\end{array}$

$1.000-1.1052$

$1.000-1.0158$

$1.000-.7993$

$\begin{array}{ll}1.000 & -.7993 \\ 1.000 & -.7302\end{array}$

$\begin{array}{ll}1.000 & -.7302 \\ 1.000 & -.9811\end{array}$

$1.000-.6724$

$1.000-.6765$

$1.000 \quad-.6790$

$\begin{array}{ll}1.000 & -.9355\end{array}$

$\begin{array}{ll}1.000 & -.9355 \\ 1.000 & -.6377\end{array}$

$1.000 \quad-.8583$

$1.000 \quad-.5462$

$1.000 \quad-.4867$

$\begin{array}{ll}1.000 \quad-.6554 \\ 1.000 & -.7425\end{array}$

$\begin{array}{ll}1.000 & -.6554 \\ 1.000 & -.7425\end{array}$

$1.000 \quad-.5188$

$1.000-.4954$

$1.000-.6627$

$1.000 \quad-.7545$

.4715

.3763

.8035

.9169

.0795

$-.0110$

.4244

.3715

.4108

.6147

.7667

.7678

.8158

.8434

.9936

1.0000

.7265

.5502

.8945

.9101

.6837

.5055

.6997

.8669

.4121

.2392

.4426

.5942

.4189

.8526

.7302

.6790

.8697

1.1052

.9811 


\begin{tabular}{|c|c|c|c|c|c|c|}
\hline & $1-5$ & -.10225 & .20710 & 1.000 & -.6912 & .4867 \\
\hline $11 \quad 15$ & $6-10$ & -.11598 & .21501 & 1.000 & -.7274 & .4954 \\
\hline $11-15$ & $16-20$ & -.12795 & .24534 & 1.000 & -.8256 & .5697 \\
\hline & $21+$ & -.33249 & .20883 & 1.000 & -.9263 & .2614 \\
\hline & $1-5$ & .02569 & .22143 & 1.000 & -.6040 & .6554 \\
\hline $16 \quad 20$ & $6-10$ & .01196 & .22885 & 1.000 & -.6388 & .6627 \\
\hline $16-20$ & $11-15$ & .12795 & .24534 & 1.000 & -.5697 & .8256 \\
\hline & $21+$ & -.20455 & .22305 & 1.000 & -.8388 & .4297 \\
\hline & $1-5$ & .23024 & .18013 & 1.000 & -.2820 & .7425 \\
\hline $21+$ & $6-10$ & .21651 & .18917 & 1.000 & -.3214 & .7545 \\
\hline & $11-15$ & .33249 & .20883 & 1.000 & -.2614 & .9263 \\
\hline & $16-20$ & .20455 & .22305 & 1.000 & -.4297 & .8388 \\
\hline
\end{tabular}

Note. "The mean difference is significant at the .05 level.

nologies is beneficial to them, however, only $26 \%$ of the respondents felt that their students expected them to use Web 2.0 technology for education.

The majority of the respondents felt that there are differences in what they taught utilizing Web 2.0 technologies versus the traditional classroom method and infusing Web 2.0 technologies within their course content was not a requirement for the majority of the participants. With regards to faculty development opportunities, the majority of the participants felt that there were many faculty development opportunities available to learn how to use Web 2.0 technologies and felt that there are many faculty development programs available while they were on campus. With regards to the varied proficiency levels of the faculty development programs and the effectiveness of the programs, the majority of the participants remained neutral. Not surprisingly, the majority of the participants agreed that they found it difficult to find the time to attend faculty development programs. The majority of the participants found it difficult to keep up with technology because it is constantly changing.

The majority of the participants agreed that students are far more advanced in technology than they are; however the majority felt that it does not take a long time to learn how to use Web 2.0 technologies. When it comes to incentives or reward programs, the majority of the participants felt that there were not many available to faculty who attend development programs on campus. The majority of the participants agreed that teaching courses utilizing Web 2.0 technologies provides more flexibility than with the traditional face-to-face method, and Almost half ( 86 or $48.6 \%$ ) of the faculty participants agree that they are self-motivated and 61 or $34.5 \%$ of the faculty participants strongly agree that they are self-motivated.

\section{Conclusion}

Based on the non-parametric chi-squared test and the oneway ANOVA tests that were conducted in the previous chapter, the following conclusions can be made:

- There is a relationship between faculty members' perception of teaching college courses utilizing Web 2.0 technologies versus the traditional classroom method.

- There is no relationship between faculty members' perception of the level of development programs and the creation of course content utilizing Web 2.0 technologies.

- There is no relationship between faculty members' perception of development programs affecting technology integration and their effectiveness.
- There is no relationship between faculty members' perception of the impact of the barriers affecting technology integration and the faculty members' ability to utilize Web 2.0 technologies.

- There is a relationship between faculty members' gender and perception regarding their use of Web 2.0 technologies in their courses.

- There is a relationship between faculty members' age and perception regarding their use of Web 2.0 technologies in their courses.

- There is no relationship between faculty members' status and perception regarding their uses of Web 2.0 technologies in their courses.

\section{Limitations}

This research study was conducted using part time and full time faculty members teaching at a public university in the United States. Generalizations to faculty members in other colleges or universities may not be relevant.

\section{Recommendations for Practice}

Based on the conclusions above, recommendations for practice include having focus groups and lunch-and-learns to openly discuss the faculty members' perceptions of teaching college courses utilizing Web 2.0 technologies versus the traditional classroom method. In addition, providing one-on-one attention to the faculty members may help the faculty members work through their perceptions. Although there is no relationship between the faculty members' perception of the level of development programs and the creation of course content utilizing Web 2.0 technologies and no relationship between faculty members' perception of development programs affecting technology integration and their effectiveness, it would be advantageous for public universities to determine the requirement level of infusing Web 2.0 technologies into courses that their university will follow and then devise specific development programs to assist the faculty from beginner to expert level with input from the faculty members. The majority of the participants in this study agreed that they learn best by doing, so the programs need to be hands-on in order to be labeled as effective.

As the study found that there is a relationship between faculty members' gender and perception regarding their use of Web 2.0 technologies in their courses, public universities should create focus groups for males and females to understand the 
difference between the male's perception and the female's perception. Reviewing the results with highest count indicates overall, the male faculty members had a higher rate on the lack of utilization with all Web 2.0 technologies while the female faculty members had a higher rate of utilization with Blogs, Facebook, Twitter and YouTube. As the study also found that there is a relationship between faculty members' age and perception regarding their use of Web 2.0 technologies in their courses, the focus groups should also be coordinated by age groups and the age groups who utilize Web 2.0 technologies more often should consider running the focus groups for the age groups who utilize Web 2.0 technologies the least. Reviewing the results with highest count indicates overall, participants in the age range of 60 - 69 have never utilized Blogs, Facebook, or Wiki; participants in the age range of 50 - 59 have never utilized Podcast, Second Life, Skype, Twitter or YouTube; participants in the age range of 40 - 49 very often utilize Twitter and Wiki; participants in the age range of 30 - 39 often utilize Blog, Facebook, Skype, Twitter, and YouTube; participants in the age range of 20 - 29 often utilize Second Life.

\section{Recommendations for Future Research}

The following recommendations are made for future research:

1) Whereas this study only included the faculty members' current employment status, future studies should develop a study to include the faculty members' department to determine the impact of the faculty members' academic department on the perception of Web 2.0 technologies.

2) Whereas this study only included public universities in the United States, future studies should develop a study to include all higher education institutions to determine the impact of the type of institution on the perception of Web 2.0 technologies.

3) Whereas this study included a One-Way Analysis of Variance (ANOVA), future research should include a Two-Way Analysis of Variance (ANOVA) to include two independent variables for additional statistical analysis.

4) Whereas this study included eight specific Web 2.0 technologies (Blogs, Facebook, Podcast, Second Life, Skype, Twitter, Wiki, and YouTube), future research should include discussion boards and journals and add course management systems such as Blackboard, Collaborate, Moodle, Prezi and Wimba as this was feedback received from the pilot study.

5) Whereas this study included a definition of terms and a neutral option in the survey, future research should include a definition of each Web 2.0 technology specified in the survey as well as an option that says "I don't know" as this was feedback received from the pilot study.

6) Whereas this study included any level of Web 2.0 technology use, future research should develop a study to compare a higher education institution that has a requirement to infuse Web 2.0 technologies within the faculty members' course content to one that does not have the requirement.

7) Whereas this study included adjuncts as the majority of the faculty participants, future research should focus on full time faculty participants as a comparison of results.

\section{Acknowledgements}

I would like to thank my doctoral mentor and committee chair, Dr. Don Gottwald, for his ability to push me beyond my limits and patiently help me along the way when I needed it. I would also like to thank Dr. Bernard Sharum and Dr. Ram Misra, who were gracious enough to also be on my doctoral committee. They were two very inspiring faculty members who, along with Dr. Gottwald, provided the support to help me successfully complete my dissertation. I simply cannot thank them enough. I was extremely blessed to have such a great committee.

In addition, I would like to thank to Dr. Yanling Sun, Cui, Andy-Guoqiang, Dr. Jinxia He, and Pamela Fallivene for their initial review of the survey and feedback, which helped structure the pilot survey. I would also like to thank all of the faculty members who took the time to complete the pilot survey as well as the main survey. If it weren't for them, this study would not be possible.

\section{REFERENCES}

Alexander, B. (2008). Web 2.0 and emergent multiliteracies. Theory into Practice, 47, 150-160. doi:10.1080/00405840801992371

Alsaady, A. (2007). Planning strategy and the use of information technology in higher education: A comparative analysis of two universities in Michigan. Doctoral Dissertation, Minneapolis, MN: Capella University.

Al-Washahi, M. (2007). The perceived effectiveness and impact of educational technology faculty development activities in the College of Education at Sultan Qaboos University. Doctoral Dissertation, Athens, OH: Ohio University.

Anderson, P. (2007). What is Web 2.0? Ideas, technologies and implications for education. Bristol, JISC Technology and Standards Watch.

Baasandorj, D. (2010). Faculty development program needs at Mongolian State Universities: Content and strategies. Doctoral Dissertation, West Lafayette, IN: Purdue University.

Baker, R., Harrison, J., Thornton, B., \& Yates, R. (2010). Podcasting in higher education: Does it make a difference? American Journal of Business Education, 3, 7-10.

Barnatt, C. (2009). Higher education 2.0. International Journal of Management Education, 7, 47-56. doi:10.3794/ijme

Chuang, H. (2004). Sustainable faculty development: Issues in technology for teacher education. Doctoral Dissertation, Ames, IA: Iowa State University.

Cooper, D., \& Schindler, P. (2008). Business research methods (10th ed.). New York, McGraw-Hill/Irwin.

Creswell, J. (2009). Research design: Qualitative, quantitative, and mixed methods approaches (3rd ed.). Thousand Oaks, CA: Sage.

Davis, F. D., Bagozzi, R. P., \& Warshaw, P. R. (1989). User acceptance of computer technology: A comparison of two theoretical models. Management Science, 35, 982-1003. doi:10.1287/mnsc.35.8.982

Dreher, C., Reiners, T., Dreher, N., \& Dreher, H. (2009). Virtual worlds as a context suited for information systems education: Discussion of pedagogical experience and curriculum design with reference to second Life. Journal of Information Systems Education, 20, 211-224.

Facebook (2012). Fact Sheet. Retrieved from http://newsroom.fb.com/content/default.aspx?NewsAreaId=22

Fillion, G., Limayem, M., Laferrière, T., \& Mantha, R. (2006). Integrating ICT into higher education: A study of onsite vs online students' perceptions. Allied Academies International Conference. Academy of Educational Leadership. Proceedings, 11, 7-10.

Fuller, M. (2011). Social media in higher education: Building mutually beneficial student and institutional relationships through social media. Master's Thesis, Johnson City, TN: East Tennessee State University.

Gilmore, S., \& Warren, S. (2007). Emotion online: Experiences of teaching in a virtual learning environment. Human Relations, 60, 581604. doi: $10.1177 / 0018726707078351$

Gottwald, W. D. (2005). A comparison of student perceptions regarding online courses and traditional courses: A case study. Doctoral 
Dissertation, Detroit, MI: Wayne State University.

Grainger, R., \& Tolhurst, D. (2005). Organisational factors affecting teachers' use and perception of information \& communications technology. In Proceedings of the 2005 south east asia regional computer science confederation (Searcc) conference (pp. 13-22), Darlinghurst, Australian Computer Society, Inc.

Halawi, L., Pires, S., \& McCarthy, R. (2009). An evaluation of e-learning on the basis of bloom's taxonomy: An exploratory study. Journal of Education for Business, 84, 374-380. doi:10.3200/JOEB.84.6.374-380

Harris, A., \& Rea, A. (2009). Web 2.0 and virtual world technologies: A growing impact on is education. Journal of Information Systems Education, 20, 137-144.

Hazari, S., North, A., \& Moreland, D. (2009). Investigating pedagogical value of wiki technology. Journal of Information Systems Education, 20, 187-198.

Hikmet, N., Taylor, E., \& Davis, C. (2008). The student productivity paradox: Technology mediated learning in schools. Communications of the ACM, 51, 128-131. doi:10.1145/1378727.1389974

International Society for Technology in Education (ISTE) (2008). NETS for teachers 2008.

http://www.iste.org/docs/pdfs/nets-t-standards.pdf?sfvrsn=2

King, J., Gurbaxani, V., Kraemer, K. L., McFarlan, F., Raman, K. S., \& Yap, C. S. (1994). Institutional factors in information technology innovation. Information Systems Research, 5, 139-169. doi:10.1287/isre.5.2.139

Laudon, K. C., \& Laudon, J. P. (2009). Essentials of Management Information Systems, Eighth Edition. Upper Saddle River, NJ: Pearson Education.

Lee, G. (2010). Second Life as an educational platform for collaborative learning by the millennial generation at a laptop university. Doctoral Dissertation, Minneapolis, MN: Walden University.

Li, L., \& Pitts, J. (2009). Does it really matter? Using virtual office hours to enhance student-faculty interaction. Journal of Information Systems Education, 20, 175-185.

Lim, W. M., \& Ting, D. H. (2012). E-shopping: An analysis of the technology acceptance model. Modern Applied Science, 6, 49-62. doi:10.5539/mas.v6n4p49

McCarthy, J. (2010). Blended learning environments: Using social networking sites to enhance the first year experience. Australasian Journal of Educational Technology, 26, 729-740.

Newman, J. (2007). The effects of synchronous voice and video tools on acceptance of online communications by students in undergraduate technology courses. Doctoral Dissertation, Reno, NV: University of Nevada.

Partnership for 21st Century Skills (2011). FAQ. http://www.p21.org/overview/p21-faq

Partnerships for 21 st Century Skills (2011). Framework for 21st Century Learning. Retrieved from

http://www.p21.org/storage/documents/1._p21_framework_2-pager .pdf

Partnerships for 21st Century Skills (2011). State Initiatives. Retrieved from http://www.p21.org/state-initiatives

Rich, M. (2008). Millennial students and technology choices for information searching. Electronic Journal of Business Research Methods, 6, 73-76.

Rockart, J. F., Earl, M. J., \& Ross, J. W. (1996). Eight imperatives for the new IT organization. Sloan Management Review, 38, 43-55.

Robey, D., \& Boudreau, M. (1999). Accounting for the contradictory organizational consequences of information technology: Theoretical directions and methodological implications. Information Systems Research, 10, 167-185. doi:10.5539/mas.v6n4p49

Sahin, I., \& Thompson, A. (2006). Using Rogers' theory to interpret instructional computer use by COE faculty. Journal of Research on Technology in Education, 39, 81-104.

Sibbet, D. (1997). 75 years of management ideas and practice: 19221997. Harvard Business Review, 75, 2-12.

Swanson, R. A., \& Holton III., E. F. (2005). Research in organizations: Foundations and methods of inquiry. San Francisco, CA: BerrettKoehler Publications.

Thompson, A. D. (2005). Scientifically based research: Establishing a research agenda for the technology in teacher education community. Journal of Research on Technology in Education, 37, 331-337.

Velez, A. (2010). Creating and sustaining virtual communities of practice by operationalizing constructs of preparation, collegiality, and professional development. Doctoral Dissertation, Minneapolis, MN: Capella University.

Wang, Y., \& Braman, J. (2009). Extending the classroom through second life. Journal of Information Systems Education, 20, 235-247.

Wankel, C. (2009). Management education using social media. Organization Management Journal, 6, 251-262. doi:10.1057/omj.2009.34

Weyant, L. E., \& Gardner, C. L. (2010). Web 2.0 applications usages: Implications for management education. Journal of Business, Society \& Government, 2, 67-78.

Williams, J., \& Chinn, S. (2009). Using web 2.0 to support the active learning experience. Journal of Information Systems Education, 20, 165-174.

Yates, S. (2009). Current faculty development practices for alternative delivery systems in Christian higher education institutions: A quailtative study. Doctoral Dissertation, Louisville, KY: The Southern Baptist Theological Seminary. 